\title{
ACORA
}

JAARGANG 27 - NUMMER 3 - 2011

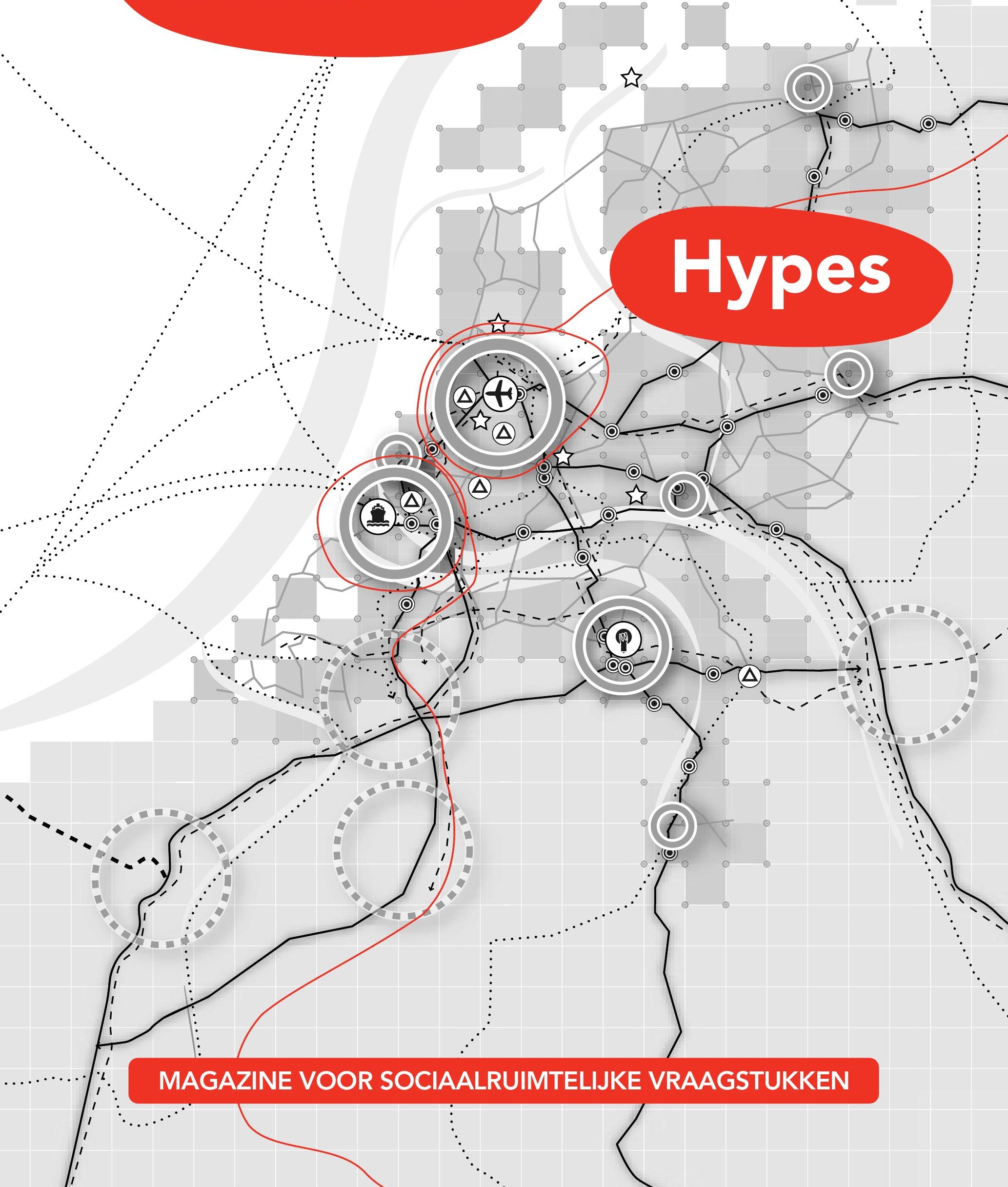




\section{Redactioneel: Gerelateerde variëteit}

\author{
ILLUSTRATIE OMSLAG Ministerie van Infrastructuur en Milieu \\ FOTOGRAFIE REDACTIONEEL Jesper van Loon \\ FOTOGRAFIE INHOUDSOPGAVE Marco Bontje
}

Als ruimtelijke ordenaar kun je niet om Jane Jacobs heen. De Amerikaans-Canadese publiciste heeft diepe invloed gehad in het denken over stedelijke ontwikkeling. De huidige generatie stedebouwkundigen is doordrongen van haar uitgangspunt: het mengen van functies. Een stad functioneert als een organisch geheel, waarin wonen, werken, consumeren en verplaatsen kriskras door elkaar plaatsvinden. Daarnaast moest planvorming volgens haar vooral uit de buurt komen. 'Bottom up', zoals dat later is gaan heten. En natuurlijk het befaamde idee van 'ogen op de straat'. Beleidsnota's reppen van 'bedrijvigheid in de plinten', want winkeliers zorgen voor sociale controle en leefbaarheid. Rotterdam neemt hierbij de ideeën van Jacobs wel heel letterlijk. Door met graffiti honderden ogen op straat te spuiten rond de ambtelijke torens aan het Marconiplein wordt het thema veiligheid - letterlijk - op de kaart gezet. Op de torens prijken levensgrote ogen. Geen woorden maar daden.

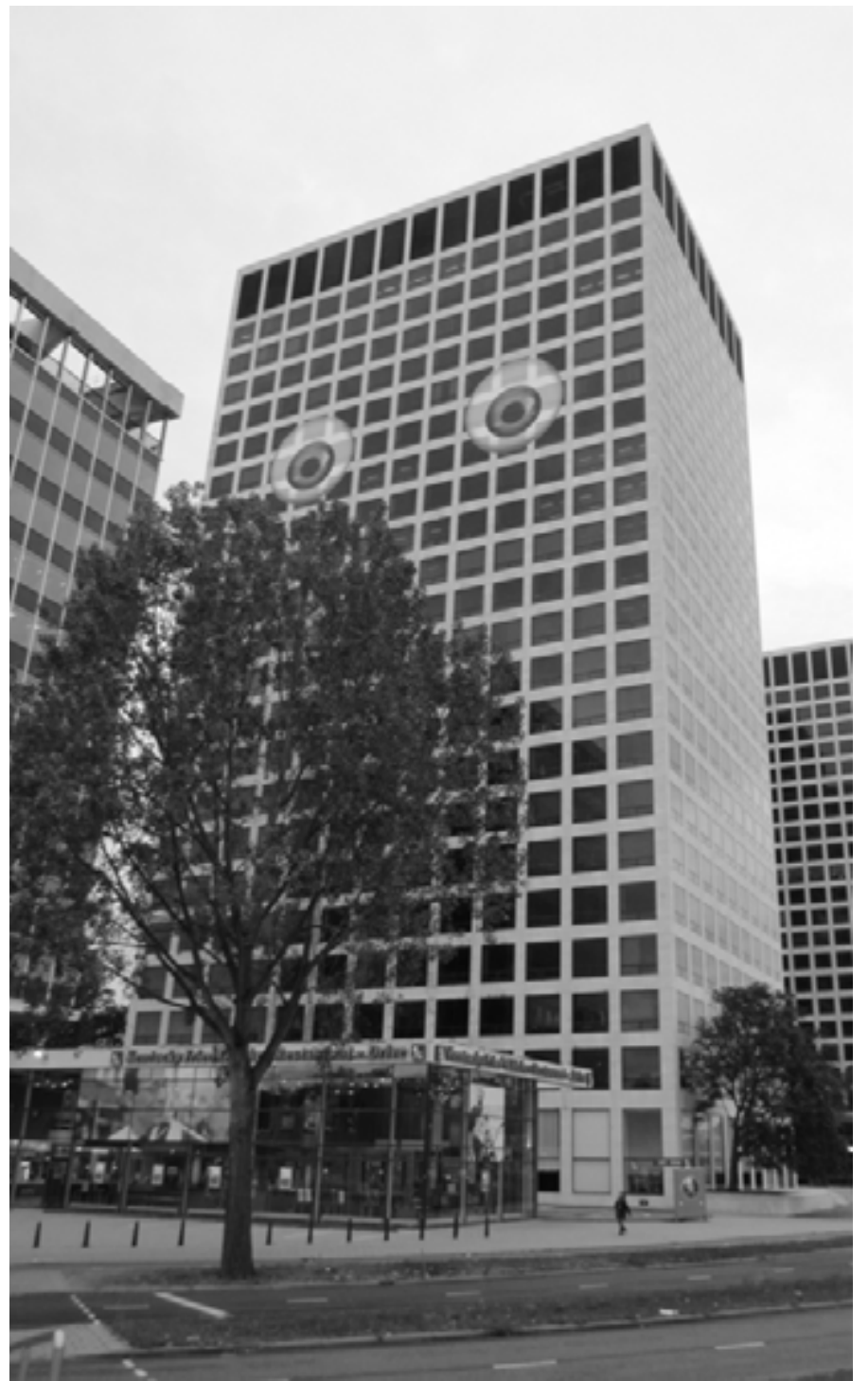

Minder bekend is het werk van Jacobs als ruimtelijk econome. De zogenaamde Jane Jacobs-externaliteiten houden in dat steden met een diverse bedrijfsstructuur het beter doen dan eenzijdig georiënteerde steden. Innovatie komt namelijk tot stand door kruisbestuiving tussen sectoren, niet binnen sectoren. Deze theorie is later aangescherpt met het begrip gerelateerde variëteit. Diversiteit is belangrijk om nieuwe ideeën op te doen, maar moet ook weer niet te groot zijn. Anders praat je simpelweg langs elkaar heen. Een schoenmaker zou bijvoorbeeld prima inspiratie kunnen opdoen bij een kleermaker, maar niet zo snel bij een planoloog. Innovatie ontstaat door de juiste balans tussen verschillen voor inspiratie en overeenkomsten voor communicatie (voor een uitgebreider college zie de recensie van Michiel van Meeteren verderop in deze AGORA).

Het maken van een geslaagde AGORA thema-editie komt eigenlijk op hetzelfde neer; op een begrijpelijke manier vernieuwende ideeën overdragen. Door over de grenzen van je eigen, veilige discipline te kijken kun je als wetenschapper of beleidsmaker tot nieuwe inzichten komen - of heb je gewoon wat te vertellen bij de koffieautomaat. Als redactie balanceren we voortdurend tussen de wens om een thema grondig uit te diepen en tegelijkertijd voor een breder sociaal-ruimtelijk publiek leesbaar en relevant te blijven. Of anders bezien: de inhoud van artikelen moet ver genoeg uit elkaar liggen om per artikel een nieuw perspectief aan te reiken, tevens voldoende gerelateerd om als thema-editie een duidelijke boodschap af te geven. De voorliggende AGORA weerspiegelt dit streven. Hypes zijn voor iedereen herkenbaar, maar tegelijkertijd ongrijpbaar. De artikelen hebben verschillende invalshoeken en onderwerpen, maar tegelijkertijd rijst er geleidelijk aan een beeld op waarin de patronen en mechanismes achter hypes steeds beter zichtbaar worden.

Gerelateerde variëteit is geen hype en zal dit vermoedelijk ook nooit worden. Hoewel kansrijk om de werkelijkheid beter te begrijpen en aan te sturen, is het niet sexy of gemakkelijk in te zetten om bestaand beleid te rechtvaardigen. Een hype staat voor exact het tegenovergestelde: lucht die mijlenver verwijderd is van wat er op straat gebeurt, maar wel invloed heeft in beleid en wetenschap. Misschien moeten we hier Jane Jacobs ook maar eens in een nieuw jasje steken. Voor een goed functionerende ruimtelijke ordening zijn namelijk niet alleen ogen op straat nodig, maar ook een scherpe blik op beleidsnota's.

Peter Pelzer, Hoofdredacteur AGORA 


\section{Inhoudsopgave: Hypes}

\section{Thema}

04 Valleien in de polder

INLEIDING Michiel van Meeteren

07 Hypes in de sociale wetenschappen

CASUS Filip De Maesschalk

10 Fixatie op de stad

ESSAY Pieter Tordoir

15 Espressocultuur in plaats van rechtvaardige steden

INTERVIEW Yvonne Rijpers

18 De creatieve hype

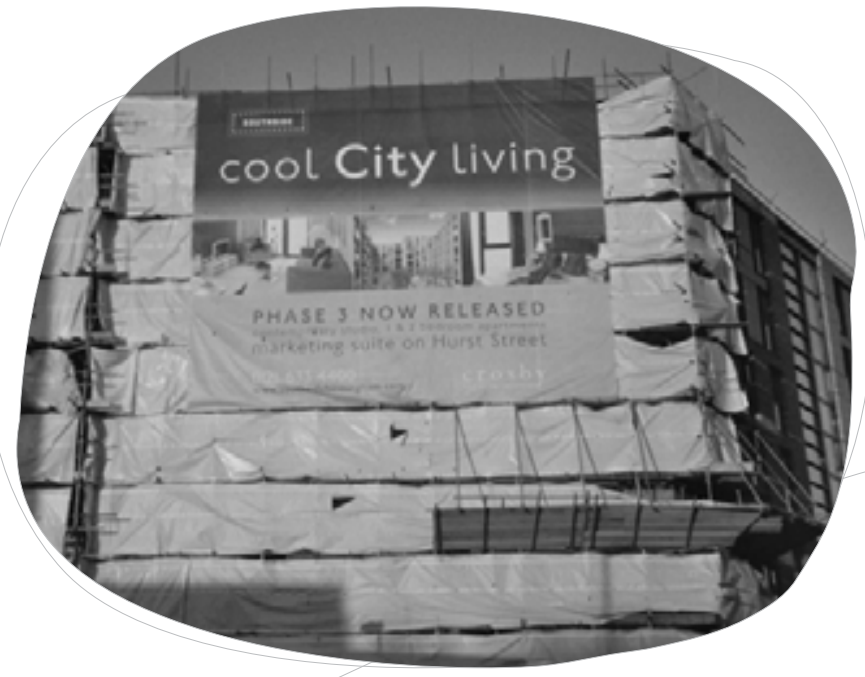

CASUS Marco Bontje \& Peter Pelzer

22 Het ruimtelijk concept als koker ESSAY Wil Zonneveld

\section{Lulkoek}

OPINIE Ewald Engelen

30 Crisis redt ruimtelijke ordening ESSAY Leonie Janssen-Jansen

Word redacteur!

AGORA is altijd op zoek naar versterking

van de redactie. Lijkt het je leuk om aan een

thema-editie te werken, een artikel te schrijven of op een andere manier bij te dragen stuur dan een mailtje naarinfo@agora-magazine.nl of vul het contactformulier op www.agora-magazine.n/ in. 


\section{Valleien in de polder}

AUTEUR Michiel van Meeteren

ILLUSTRATIE Thomas Vanoutrive

Ruimtelijke hypes spelen een belangrijke rol in de beleidspraktijk. Vijf jaar geleden was het blijkbaar essentieel voor de economische toekomst om de creatieve klasse te binden, tegenwoordig lijkt een economisch 'topcluster' binnen de stadsgrenzen een vereiste. Hoe werkt die hypedynamiek eigenlijk?

Op 11 november 1999 knipte de Belgische kroonprins Filip het spreekwoordelijke lint door bij de officiële opening van het leperse Language Valley. Het was het hoogtepunt van een goudkoorts die de jaren daarvoor ontstaan was rondom het spraaktechnologiebedrijf Lernaut \& Hauspie. Dit bedrijf zou de technologie ontwikkelen waarmee computers en mensen in de toekomst zouden gaan communiceren en trok in haar kielzog van heinde en verre investeerders aan. Microsoft legde 45 miljoen dollar in en talloze verwante bedrijfjes vestigde zich in het nieuwe industriepark. Language Valley, met een guitige knipoog naar het Amerikaanse Silicon Valley, was het lichtend voorbeeld voor Vlaanderen haar economisch beleid dat als motto "Valleien aan het werk, werk in de vallei" droeg. Ook de ruimtelijke wetenschap deelde mee in jubelstemming. Zo schreven de Maastrichtse onderzoekers Wintjes en Cobbenhagen in datzelfde jaar dat "men eindelijk de woorden van de burgemeester van leper kan geloven toen hij zei dat Language Valley net zo belangrijk zou worden als de textielindustrie in de twaalfde en dertiende eeuw was". Nog geen jaar later was het feest voorbij. Het Vlaamse Apple bleek het Vlaamse Enron te zijn: boeken waren vervalst en dochterondernemingen bleken niet te bestaan. Uiteindelijk zouden de directeuren van het bedrijf veroordeeld worden tot celstraffen, en in hetzelfde jaar maakte de dotcomcrisis een einde aan menig gedroomd siliciumparadijs. Zo was de fut ook uit Silicon Glen in Schotland en heet Silicon Seaside sindsdien weer gewoon ZuidNoorwegen.

Tien jaar later, in 2010, heeft de valleienhype Nederland bereikt. In oktober van dat jaar stuurt minister Verhagen van Economische Zaken, Landbouw en Innovatie een brief naar de Tweede Kamer met de titel: "Naar de top: hoofdlijnen van het nieuwe bedrijvenbeleid." In deze brief wordt aangekondigd dat de Nederlandse nationale overheid voornamelijk geld wil investeren in een aantal Nederlandse regionaal-economische topsectoren. Onder andere 'Energy Valley', 'Maintenance Valley' en 'Food Valley' worden met naam genoemd. Als men nader kijkt blijkt dan de kern van Energy Valley te bestaan uit het Gasunie complex te Slochteren en een aantal geplande kolencentrales in de Eemshaven, en loopt Food Valley van de varkensflats in de Peel via de landbouwuniversiteit Wageningen naar de kippenfabrieken rondom Barneveld. Inmiddels schieten de valleien in Nederland als paddenstoelen uit de grond. Gelderland en Overijssel heten tegenwoordig 'Health Valley', maar dat moet stevig concurreren met een samenwerkingsverband van Amsterdamse en

\section{Beleidsmakers willen graag de ambities die hun brood- heren verkopen waarmaken}

Utrechtse ziekenhuizen dat samen met de farmaceutische industrie onder de naam 'Immuno Valley' aan de weg timmert. Het gebied rond Enkhuizen verkoos de naam 'Seed Valley' boven het oerHollandse Zaadvallei. Dit gebied grenst aan 'Medical Valley', wat de nieuwe naam is voor de duin waar de Pettense kerncentrale opstaat. Tot slot is 'Metal Valley' in Drunen anders dan u zou denken toch geen popfestival en komt het Hilversumse avondjournaal tegenwoordig uit 'Media Valley'. Geen van deze plekken zal ooit iets worden dat vergelijkbaar is met Silicon Valley, maar toch kiezen ze allemaal voor een dergelijk uitgekauwd anglicisme. Een nieuwe ruimtelijke hype is geboren, al blijkt deze in internationaal perspectief allesbehalve nieuw te zijn. Opvallend is dat de ruimtelijke wetenschap, na 


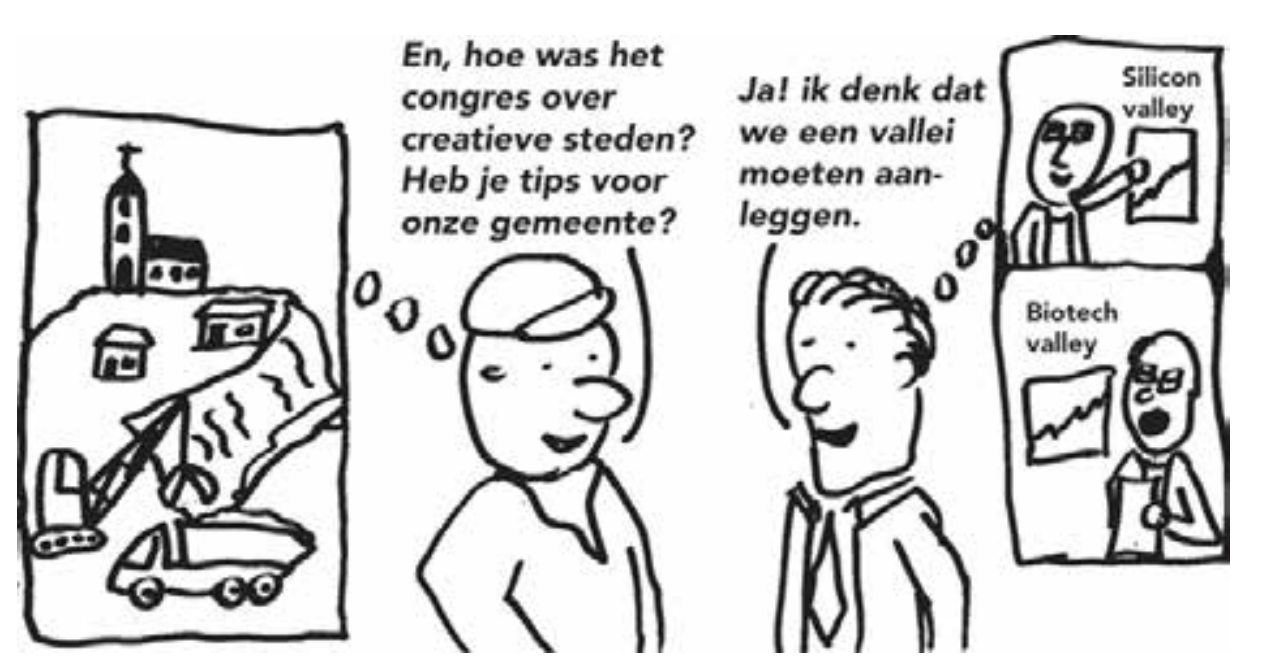

de infame creatieve klasse, opnieuw zo'n grote rol speelt in de oorsprong van dit hypeconcept. Hoewel de naam 'Silicon Valley' begin jaren zeventig door een lokale Californische ondernemer is bedacht, zijn het vooral (economisch) geografen die het narratief en het veronderstelde kookboek hebben geconstrueerd waarmee je een dergelijk economisch succes zou moeten reproduceren. Hoog tijd dus om een AGORA te wijden aan de dynamiek van deze ruimtelijke hypes. Hoe ontstaan ze? Waarom worden sommige ruimtelijke concepten en modellen zo populair? Wie hebben belang bij de hypes? Wat zijn eigenlijk de risico's van door hypes gedreven beleid?

\section{Denkramen en fixaties}

Een ruimtelijke hype is in feite een narratief, of discours, dat overdreven veel aandacht krijgt of overdreven vaak gebruikt wordt ten opzichte van de claims die we op basis van dat narratief mogen doen. In die definitie zitten twee vragen verscholen die we bij elke ruimtelijke hype moeten stellen: Wat is het onderliggende verhaal eigenlijk, en waarom wordt nou juist dát verhaal zo populair? Ruimtelijke narratieven geven een perspectief op de sociaalruimtelijke werkelijkheid. Er zijn vele verhalen die we over de kerncentrale in Petten kunnen vertellen, maar door een analogie met Silicon Valley te suggereren praten we eerder met elkaar over de economische kansen die deze - voornamelijk medische isotopen producerende - centrale biedt dan de ook aanwezige risico's. Het aanroepen van een ruimtelijk narratief zet de discussie in een bepaald denkraam, wat in de Engelstalige literatuur 'framing' genoemd wordt. Denkramen sturen onze definitie van de situatie en zetten sommige discussies centraal terwijl ze anderen naar de periferie van onze aandacht duwen. Maar waarom worden bepaalde denkramen dan een hype en anderen niet? Waarom kiezen zoveel regionaal-economische allianties hetzelfde narratief? In de managementwetenschap zijn bestuurskundige hypes al jaren schering en inslag en heeft men dus ook hier al eerder onderzoek naar gedaan. De belangrijkste vraag in de managementwetenschap is of de zogenaamde 'best practices' een hype worden omdat ze inderdaad de beste praktijk zijn, en het kiezen van het model dus een rationele keuze is, óf dat managers vooral elkaar klakkeloos imiteren. David Strang en Michael Macy stellen dat dergelijke hypes ontstaan doordat men rationeel probeert een ambitie te verwezenlijken en daarmee vooral naar elkaar loert wat daarvoor het beste model is. In hun woorden: "Juist omdat er een enorme prestatiedruk ligt ontstaan hypes: consultants adverteren met winnaars, niet met genuanceerde beelden, en beleidsmakers willen graag de ambities die hun broodheren - de politici - verkopen ook waarmaken". De Amerikaanse wetenschapster Ann Markusen schreef in 1999 al dat de geografie een neiging had theorieën te produceren die zodanig vaag zijn dat ze overal op toepasbaar lijken en vaak niet te weerleggen zijn. Dat zorgt er ook voor dat de (quasi-) wetenschappelijk beschreven succesverhalen zich ook makkelijk lenen om overal opgeplakt te worden. Maar er is meer aan de hand: Er zijn helemaal niet zoveel verschillende verhalen en denkramen voorhanden. Filip de Maesschalk laat in zijn artikel in deze AGORA zien dat de hype eigenlijk al in de wetenschap zelf begint. Onderzoeksagenda's worden gedreven door citatie-indexen en dus doen heel veel mensen onderzoek naar hetzelfde onderwerp om meer geciteerd te worden, waarmee een vicieuze cirkel in stand gehouden wordt. Hetzelfde geldt voor plekken: bepaalde steden krijgen in het onderzoek veel meer aandacht dan andere, en daardoor weten we collectief veel minder over variatie in contexten dan dat je op basis van het aantal mensen dat zich met een onderwerp bezig houdt zou verwachten.

Denkramen zorgen ook voor vereenvoudiging, en tot wat Pieter Tordoir in zijn artikel fixatie noemt. Tordoir reflecteert op het concept 'stad' en haar verschillende betekenissen. Hoewel volgens Tordoir stedelijke economieën wel degelijk bestaan, hebben deze al lang niet meer de fysieke structuur die de gemiddelde mens met het begrip 'stad' associeert. Tegelijkertijd is de stad ook een actor, een overheid die alle belang heeft om zich op te werpen als de belichaming van economische krachten die haar grenzen de facto ver overstijgen. De schaalniveaus van de ruimtelijke verbeelding en de economische werkelijkheid die die verbeelding moet representeren lopen uiteen. Men zou kunnen beargumenteren dat het de rol van de wetenschap is om dit uiteenlopen van beeld en werkelijkheid aan de kaak te stellen, echter de verleiding om gebruik van te maken van die discrepantie is groot. AGORA sprak met de Amerikaanse stadssociologe Sharon Zukin onder meer over dit dilemma. Haar nieuwste boek, Naked City, is bewust op zo'n manier geschreven dat het aansluit bij de belevingswereld van de gegentrificeerde New Yorkse bewoners wiens gedrag ze met haar boek wil beïnvloeden. Zij 
maakt dus gebruik van de al levende denkramen en fixaties in een poging die te veranderen. Naar haar idee heeft ze zo een grotere impact op het welzijn van de wereld dan wanneer ze binnen de universiteit een verhaal blijft prediken dat door burgers en beleidsmakers gewoon genegeerd wordt. Echter, we moeten de macht van de wetenschapper zeker niet overschatten. Om dat te illustreren gaan Marco Bontje en Peter Pelzer terug naar wat wel de grootste ruimtelijke hype is geweest het afgelopen decennium: Richard Florida en zijn creatieve klasse theorie. Uit hun onderzoek blijkt dat Florida vooral erg populair was onder beleidsmakers omdat de theorie al bestaand beleid legitimeerde. De werkelijke impact van zijn werk is dus lang niet zo groot als vaak wordt aangenomen.

\section{Conformeren aan ruimtelijke hypes om uit de subsidiepot te mogen mee-eten}

\section{Consequenties van hypes}

Met die legitimatie komen we dan ook terecht bij de vraag wat ruimtelijke hypes nu eigen-lijk voor functie hebben in de wereld van beleid en bestuur. Wil Zonneveld laat zien hoe wetenschappelijke hypes 'stollen' in beleidsinstrumenten en hoe ze na verloop van tijd onderdeel worden van routines. Hierdoor verdwijnt de vraag uit het zicht of een bepaald denkraam eigenlijk wel past op een maatschappelijk fenomeen en of we met $z^{\prime} n$ allen niet zouden moeten zoeken naar een beter alternatief. Zonneveld zijn artikel geeft ons verder een eerste verklaring waarom hedendaags Nederland bezaaid is met valleien: conformisme aan ruimtelijke hypes vindt ook plaats om uit de landelijke subsidiepot te mogen mee-eten. Wil minister Verhagen topregio's? Dan krijgt hij ook topregio's! In ieder geval op papier. Ewald Engelen trekt deze lijn in zijn artikel verder door. Volgens hem zijn de verhalen en hypes waarmee beleid verantwoord wordt vooral lulkoek. Niets meer en niets minder dan een manier waarop particuliere belangen worden verkocht als algemeen belang. Volgens Engelen weet de bestuurselite dat ook dondersgoed, maar zijn kritiek treft vooral de wetenschap die zich steeds weer leent om als schaamlap in plaats van hoeder van het publieke debat te dienen. De vaagheid in de theorieën is dus instrumenteel. Het zorgt ervoor dat mensen niet afgerekend kunnen worden op hun politieke besluiten. In het afsluitende artikel van dit nummer van Leonie Janssen-Jansen, krijgen we een indruk wat de materiële gevolgen van een door hypes gedreven beleid kunnen zijn. Eén van de consequenties van de ambitie tonen om topregio te worden is dat je beleid maakt dat rekening houdt met het slagen van zo'n ambitie. Het is dan ook nog maar een kleine stap tot dat een overheid zo sterk voor die ambitie gaat vechten dat ze er zelf in gaat geloven. Janssen-Jansen beschrijft wat het collectief wedden op het meest optimistische groeiscenario voor gevolgen heeft gehad voor de Nederlandse ruimtelijke ordering. Doordat vele gemeenten hebben geïnvesteerd in nieuwe kantoren en bedrijventerreinen hebben we er veel te veel en zakken grondexploitaties door hun hoeven. De risico's van een hype worden dan pas duidelijk: Als we collectief de werkelijkheid toch niet juist hebben gekaderd dan hebben we misschien ook de risico's onjuist gedefinieerd. De prijs van hypegedreven beleid komt dan pijnlijk duidelijk bij de belastingbetaler te liggen. Uiteindelijk moeten tekorten uit de schatkist betaald worden en die situatie zal echt niet veranderen door het financiële tekort in een ander denkraam te plaatsen.

\section{Hypecycli}

Rest de vraag hoe we hier dan lering uit kunnen trekken en ervoor kunnen zorgen dat beleid in overeenstemming blijft met de werkelijkheid. Leidt een pleidooi voor meer realisme niet al snel tot gelatenheid en het missen van de boot? In ieder geval lijkt het duidelijk dat Nederland meer kan leren uit het nabije 'Language Valley' dan het verre 'Silicon Valley' en zou minister Verhagen wat vaker ervaringen met de zuiderburen mogen uitwisselen. Wat opvalt, is dat er een enerzijds een hypecyclus is waar zowel de wetenschap als het beleid in meegaat. Collectief wordt er veel te veel achter rages aangerend, zeker in het beleidsdiscours. Anderzijds blijkt dat sommige thema's verhuld in nieuwe hypes onder een andere naam steeds terugkomen. Zo handelt AGORA 2002-1 al over de risico's van interstedelijke concurrentie en gebrek aan afstemming, en kunnen wij ook niet anders dan concluderen dat er de afgelopen tien jaar wat dat betreft weinig is veranderd. Ook moeten we vaststellen dat het te dicht tegen elkaar aanschuren van wetenschap en beleid de hypecyclus in de hand werkt, iets waar AGORA aandacht aan besteedde in nummer 2005-1. Mocht u zich willen wapenen tegen de volgende hype: Beide nummers zijn gratis digitaal verkrijgbaar op www.agora-magazine.nl.

\section{Michiel van Meeteren (michielvanmeeteren@gmail.com) is economisch geograaf en socioloog. Zijn onderzoek richt zich op economische netwerkvorming tussen Nederland en Oost-Azië. Verder is hij redacteur bij AGORA.}

Literatuurselectie

Cornwall, A. (2007), Buzzwords and fuzzwords: deconstructing development discourse. Development in Practice, 17, no.4/5, pp. 471-484.

Goffman, E. (1974), Frame Analysis, an essay on the organization of experience. Boston: Northeastern University Press.

Hospers, G-J., Desrochers, P. \& Sautet, F. (2009), The next Silicon Valley? On the relation-ship between geographical clustering and public policy. International Entrepreneurship and Management Journal, 5, pp. 285-299.

Markusen, A. (1999), Fuzzy concepts, scanty evidence and policy distance: the case for rigour and policy relevance in critical regional studies. Regional Studies, 33, pp. 869-884

Strang, D. \& Macy, M. (2001), In search of excellence: Fads, success stories and adaptive emulation. American Journal of Sociology, 107, no.1, pp. 147-182

Wintjes, R. \& Cobbenhagen, J. (1999) Flanders Language Valley; Industrial districts and localized technological change. www.merit. unu.edu/publications/rmpdf/1999/rm1999-033.pdf 


\section{Hypes in de sociale wetenschappen}

AUTEUR Filip De Maesschalk

Hypes worden vaak geassocieerd met maatschappelijke sectoren als cultuur en media, met politici en hun electorale bekommernissen, en met beleidsconcepten. Staan de sociale wetenschappen ook onder invloed van hypes? In deze bijdrage duiken we in de Social Science Citation Index (SSCI) om het ontstaan van hypes in de wetenschappelijke literatuur te illustreren.

Het is duidelijk dat bepaalde concepten in de sociale wetenschappen op een bepaald moment erg populair zijn, veelvuldig gebruikt worden in publicaties, om vervolgens weer in de vergetelheid te belanden. Anderen zijn blijvers. De plotse aantrekkingskracht van bepaalde concepten blijkt bijvoorbeeld wanneer we kijken naar twee belangrijke processen die onze Westerse steden vormgeven:

suburbanisatie en gentrificatie. Het aantal artikels dat over gentrifica-

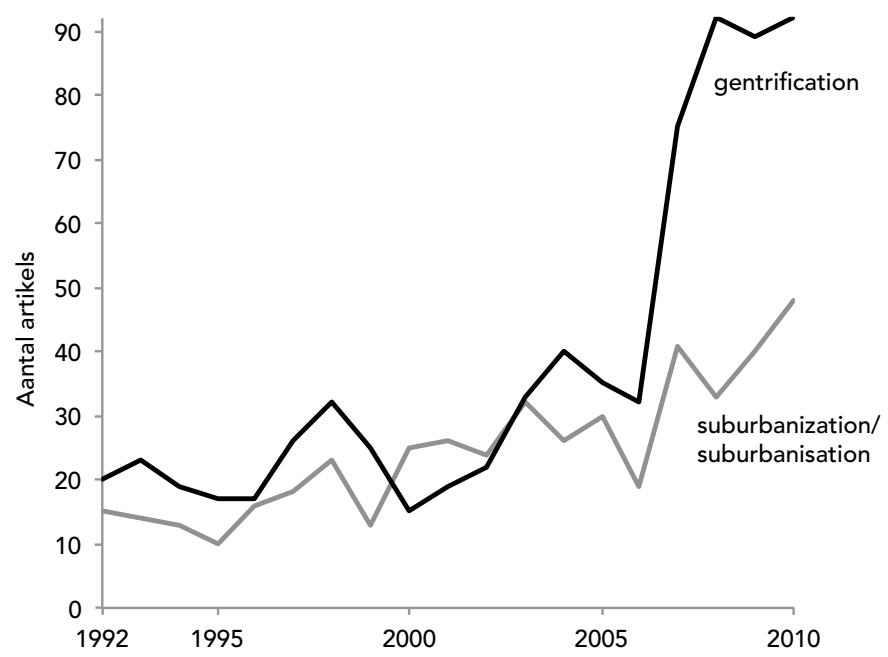

Aantal artikels over suburbanisatie en gentrificatie in de SSCI, 1992-2010 tie handelt, wordt vanaf het begin van de jaren negentig geleidelijk aan groter dan het aantal artikels over suburbanisatie. Gentrificatie is dan ook een recenter begrip dan suburbanisatie. Tegelijkertijd blijft suburbanisatie onze steden structureren, ook al wordt er relatief minder over gepubliceerd. De laatste jaren verloopt de groei van het aantal publicaties over gentrificatie echter exponentieel. Onderstaande grafiek toont deze evolutie. Zij geeft het aantal artikels weer waarin gentrificatie dan wel suburbanisatie een onderwerp zijn in de afgelopen twintig jaar. Dit wil zeggen dat de opgegeven term voorkomt in de titel, in de abstract, in de keywords van de auteur of in de automatisch aangemaakte keywords die de SSCl gebruikt op basis van veel gebruikte woorden in titels van geciteerde teksten (sinds 1991). Bij dit soort grafieken moet vooral naar die verschillen worden gekeken, aangezien het totaal aantal citaties van jaar tot jaar toeneemt. Zo waren er in 1992125.000 artikels opgenomen in de SSCl. In 2010 zijn er dat bijna 220.000.

De SSCl speelt een sleutelrol in de sociaal-wetenschappelijke praktijk. Wanneer het gaat om financiering, academische benoemingen en promoties is het aantal artikels dat een onderzoeker of onderzoeksgroep in de SSCl gepubliceerd heeft van doorslaggevend belang. Er is meermaals beargumenteerd dat bepaalde topics meer kans hebben om gepubliceerd te worden als ze vaak voorkomen in deze database. De SSCl bepaalt dus mee wat onderzocht wordt en wat niet en dit kan ook een zichzelf versterkend effect hebben. De database heeft dus een rechtstreekse invloed op de wetenschappelijke praktijk. In deze bijdrage gaan we verder dan het loutere gebruik van bepaalde concepten, en gaan we na of hypevorming zich ook voordoet op twee essentiële domeinen: theorievorming en ruimtelijke referentiekaders. Zijn bepaalde theoretici op een bepaald moment erg populair, om dan weer wat vergeten te worden? En wat zijn de dominante ruimtelijke referentiekaders: welke concrete plaatsen worden gebruikt om theorieën en concepten op te bouwen, te toetsen of te illustreren. En wat zijn hierin de ontwikkelingen? 


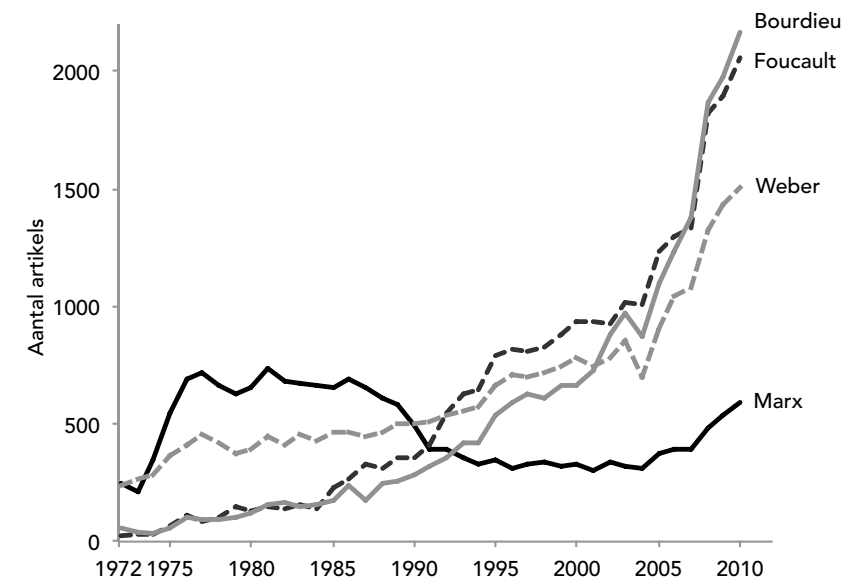

Aantal artikels in de SSCI waarin Marx, Foucault, Bourdieu en Weber worden geciteerd, 1972-2010

Marx is dood, leve Foucault!

Het gebruik van bepaalde theoretici is sterk afhankelijk van de tijdsgeest. Zo kent Karl Marx heel wat succes in de crisisjaren zeventig en tachtig, maar kwijnt hij sindsdien wat weg, al leeft hij recent weer wat op. Dit is duidelijk wanneer we kijken naar het aantal artikels waarin Marx wordt geciteerd (grafiek links), maar ook wanneer we kijken naar het aantal artikels dat Marx expliciet als topic heeft (grafiek rechts). Dat dit niet geldt voor alle klassieke theoretici, wordt aangetoond door Max Weber. Zowel het aantal artikels waarin Weber wordt geciteerd als het aantal artikels met Weber als topic kent een geleidelijke groei. Het is natuurlijk geen toeval dat Marx' populariteit vooral inzakt na de val van de communistische regimes.

\section{Theorieën en concepten breken vaak pas door als er Engelse vertalingen verschijnen}

De reddingsboei wordt gevormd door de Franse filosofen Michel Foucault en Pierre Bourdieu. Zij worden vanuit een marginale rol naar een voorname plaats gekatapulteerd: zij laten Max Weber vlot achter zich.

De stijgende populariteit van de Franse filosofen loopt samen met het toenemend aantal Engelse vertalingen van deze auteurs die op de markt komen. Theorieën en concepten die in een niet-Engelse context werden ontwikkeld breken vaak pas door in de $\mathrm{SSCl}$ als er Engelse vertalingen verschijnen of, vaker nog, wanneer Engelstalige auteurs de Angelsaksische markt openen door over hen te schrijven. De volgende grafiek is in die context interessant. Zij toont het aantal artikels waarin een aantal theoretici van de regulatiebenadering worden geciteerd. Regulationisten trachten verschillen in economische en sociale dynamiek in tijd en ruimte te verklaren in een situatie

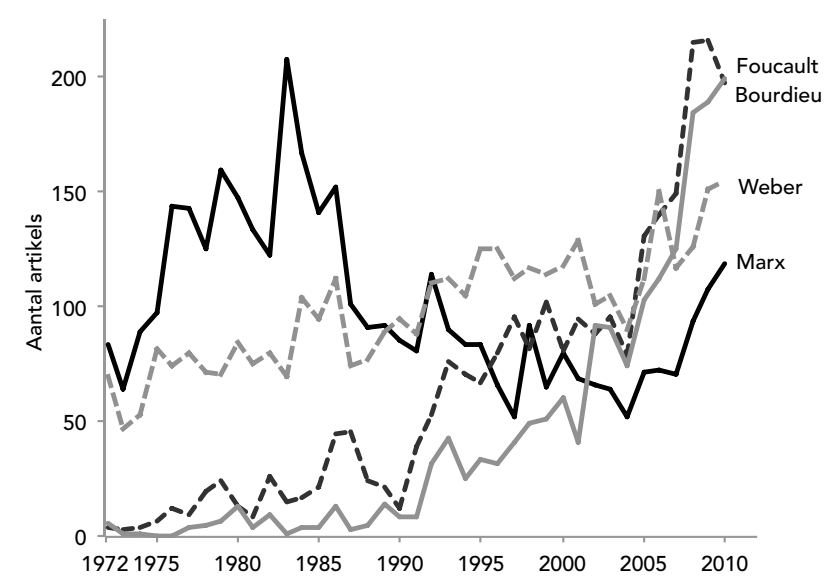

Aantal artikels over Marx, Foucault, Bourdieu en Weber in de SSCI, 1972-2010

waar de kapitalistische productiewijze dominant is, via een aantal intermediaire concepten als accumulatieregimes en regulatiewijzen. Enkele pioniers van de regulatiebenadering, Alain Lipietz en Michel Aglietta van de zogenaamde Parijse School, kennen een zeker succes in de jaren tachtig en negentig, maar het zijn vooral de Angelsaksische auteurs die zich naderhand in de regulatiebenadering hebben ingeschreven, zoals Bob Jessop, die dus ook hoog scoren in de SSCl.

Dit stijgend succes verbleekt echter bij de steile opgang van sommige anderen, die binnen een geheel ander theoretisch kader werken. Een mooi voorbeeld is Richard Florida. Sinds hij zijn beststeller The Rise of the Creative Class schreef, waarin hij de rol van een creatieve klasse in de economische ontwikkeling en het concurrentievermogen van steden analyseert, is Florida een ware hype in beleidskringen. Ook in de sociale wetenschappen is dit het geval. Hij komt uit het niets in de jaren tachtig en wordt in meer dan vierhonderd artikels geciteerd in 2010.

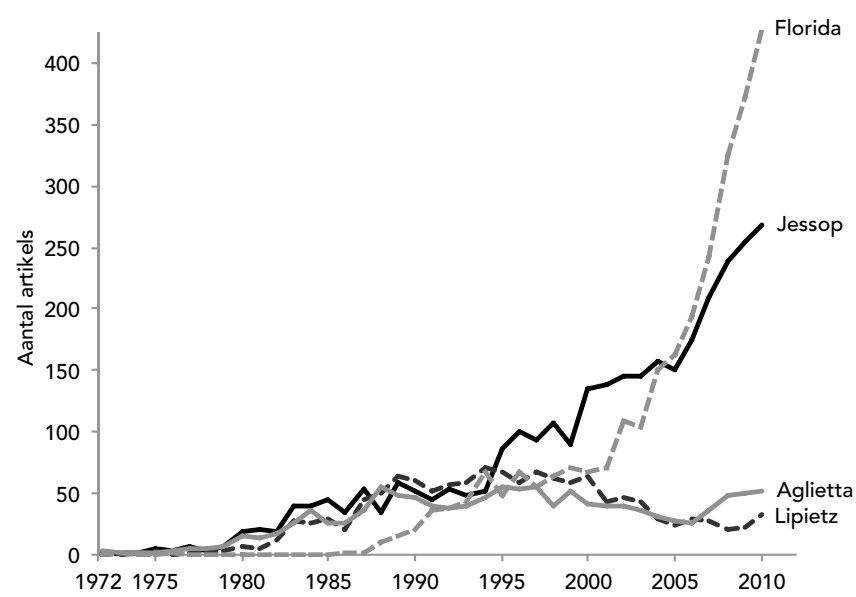

Aantal artikels in de SSCI waarin Jessop, Lipietz, Aglietta en Florida worden geciteerd, 1972-2010 
De Chinezen komen!

Laten we tenslotte eens kijken naar de ruimtelijke referentiekaders die worden gebruikt. Welke concrete plaatsen vormen de basis, de toetssteen of de illustratie van theorieën of concepten? We keren terug naar het onderzoek over steden, en kijken naar het aantal artikels dat een bepaalde stad als topic heeft. Wanneer we een rangschikking maken, over alle jaren heen, van de populariteit van de grootste steden in de verschillende continenten, blijkt de Angelsaksische dominantie bijzonder sterk. Parijs is de enige stad die de top vijf haalt. New York, Londen en enkele andere Amerikaanse steden maken de lijst vol. En het verschil is groot: Parijs heeft er iets meer dan 5.000, Londen meer dan 12.000 en New York meer dan 21.000. Ter vergelijking: Amsterdam heeft er nog geen 2.000, Brussel nog geen duizend.

\section{Bepaalde steden zijn plots erg populair, terwijl andere grote steden amper worden betrokken in het onderzoek}

Ook hier zijn verschillende ontwikkelingen in de tijd. De hype van het moment zijn de Chinese steden. Zo is de aandacht voor de twee grootste Chinese steden, Shanghai en Beijing, bijzonder sterk gegroeid, hoewel zij nog lang niet aan Londense (710 in 2010) of New Yorkse (1.135 in 2010) cijfers zitten. Het contrast met de twee grootste Afrikaanse steden is groot. Het gaat om de Egyptische hoofdstad Cairo en de Nigeriaanse stad Lagos - steden die niet tot de zogenaamde BRICS-landen (Brazilië, Rusland, India, China en Zuid-Afrika) behoren. Zulke steden zijn helemaal geen hypes. Zij blijven quasi afwezig in het debat. Concepten worden niet ontwikkeld en theorieën niet getoetst. Nochtans zijn de uitdagingen in zulke steden enorm, niet alleen inzake sociale ongelijkheid, maar ook inzake ruimtelijke ordening. We moeten ook -en vooral- oog hebben voor wat niet de hype van het moment is.

\section{Conclusie}

Wanneer we de $\mathrm{SSCl}$ als maatstaf nemen, blijkt dat ook de sociale wetenschappen onder invloed staan van hypevorming. Gezien publicatie in tijdschriften die opgenomen zijn in de SSCl van groot belang is voor iemands academische carrière, moet de vraag worden gesteld of de (im)populariteit van bepaalde thema's niet samenhangt met de perceptie ervan als meer of minder geschikt voor publicatie. Hypevorming is niet alleen duidelijk bij het gebruik van bepaalde thema's, maar ook bij het gebruik van bepaalde theoretici. Bepaalde auteurs komen snel op, andere boeten snel in aan populariteit. Dat zien we nog meer bij het gebruik van ruimtelijke referentiekaders. Bepaalde steden -vaak in economische groeilanden- zijn plots erg populair, terwijl een hele reeks andere grote steden -waar de uitdagingen niet minder groot zijn- amper worden betrokken in het onderzoek. Er worden daar geen concepten ontwikkeld of theorieën

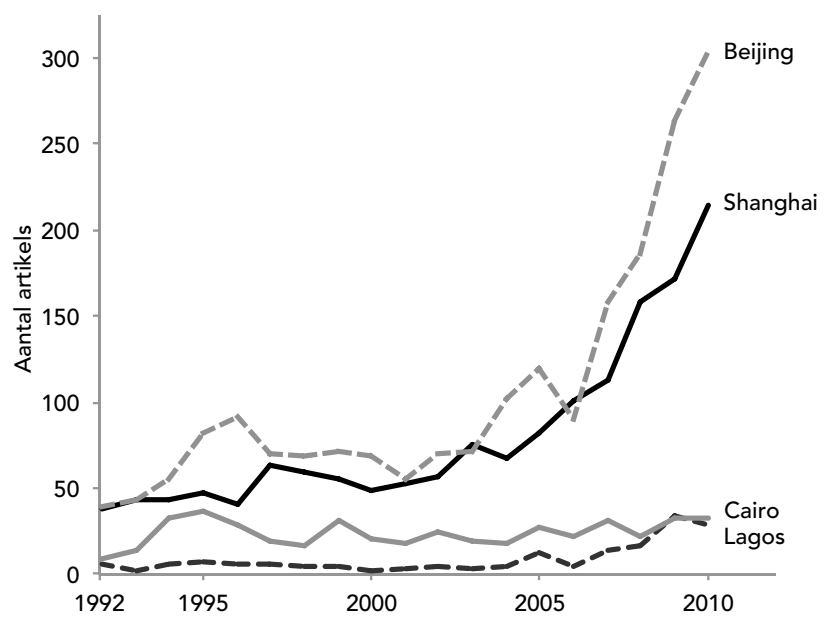

Aantal artikels over Shanghai, Beijing, Cairo en Lagos in de SSCI, 1992-2010

getoetst. Bij dit alles blijkt steeds het grote overwicht van het Angelsaksisch onderzoek. Het is dus belangrijk stil te staan bij de vraag wat onderzocht wordt, hoe het onderzocht wordt, en vooral waarom dat zo is.

Filip De Maesschalck (filip.demaesschalck@ees.kuleuven.be) is doctor in de geografie, verbonden aan het Instituut voor Sociale en Economische Geografie van de K.U. Leuven en werkt momenteel op de dienst sociale planning van de provincie VlaamsBrabant in België.

Literatuurselectie

Aalbers, M.B. \& Rossi, U. (2007) A coming community: young geographers coping with multi-tier spaces of academic publishing across Europe. Social \& Cultural Geography, 8 (2), pp. 283-302. Bodman, A.R. (2010) Measuring the influentialness of economic geographers during the 'great half century': an approach using the $h$ index. Journal of Economic Geography, 10 (1) pp. 141-156. Bosman, J. (2009) The changing position of society journals in geography. Tijdschrift voor Economische en Sociale Geografie 100 (1), pp. 20-32.

Dicken, P., et al. (2004) Classics in Human Geography revisited: Global shift: industrial change in a turbulent world, Progress in Human Geography, 28 (4) pp. 507-515.

Dolfsma, W., Leydesdorff, L. (2009) Economie en bedrijfskunde evalueren. Economisch Statistische Berichten 94 (4559), pp. 1-3. Schuermans, N., Meeus, B. \& De Maesschalck, F. (2010) Is there a world beyond the Web of Science? Publication practices outside the heartland of academic geography, Area, 42 (4), pp. 417-424. Smeyers, P. \& Burbules, N.C. (2011) How to Improve your Impact Factor: Questioning the Quantification of Academic Quality, Journal of Philosophy of Education, 45 (1), pp. 1-17 


\section{Fixatie op de stad}

AUTEUR \& FOTOGRAFIE Pieter Tordoir

Weinig onderwerpen staan zo centraal in het wetenschappelijke en maatschappelijke discours en zijn tegelijkertijd zo ongedefinieerd als het geval is met de stad. De stad als economisch, sociaal of cultureel systeem bestaat niet (meer) en is, misschien juist wel daarom, als fixatie terecht gekomen tussen onze oren. Wat moeten we daarmee als geograaf en planoloog?

Het gaat te ver om de populariteit van het oude en eerbiedwaardige begrip stad als hype te beschouwen. Maar toch, als we een hype definiëren als collectieve fixatie op een begrip of verschijnsel dat geen ontologische basis kent, zich leent voor grote interpretatieverschillen maar desalniettemin een invloedrijk eigen leven leidt, dan komt die populariteit wel in de buurt. Aan steden worden belangwekkende eigenschappen toegedicht. Zo zouden steden economisch concurreren, creativiteit aantrekken of opwekken, of juist vervreemding in de hand kunnen werken. Steden worden breed beschouwd als niet zomaar een realiteit maar één die typerend is voor onze complexe economie en samenleving, een realiteit die bovendien nastrevenswaardig is en waar zelfs handelende eigenschappen aan worden toegedicht. Als onderwerp van het discours en frames die tot handelen en beleidskeuzes leiden is het stadsbegrip in ieder geval invloedrijk, zoniet leidend in de ruimtelijke ontwikkelingspraktijk in Nederland. De indruk bestaat dat die invloed toeneemt, getuige bijvoorbeeld de aandacht voor de stad in politieke partijprogramma's. Het is daarom interessant om het stadsbegrip kritisch te verkennen. Dat gebeurt wonderlijk genoeg weinig. Dit artikel doet een aanzet.

De stad als morfologisch object

Om van een stad te kunnen spreken zal er toch sprake moeten zijn van een ruimtelijk af te bakenen zwerm occupaties van bovengemid- delde omvang en dichtheid die - en dat is het belangrijkst - door interne samenhang in zeker opzicht als eenheid functioneert. Nu leiden eenvoudige graviteitsmodellen van de ruimtelijk economische wetenschap, de ruimtelijke subdiscipline met de grootste claim op verklaringskracht, op blanco papier inderdaad tot stelsels van samenhangende klompen occupaties. Wil Zonneveld betitelt dit elders in deze uitgave als bolletjessteden. Transportkosten in markten leiden tot agglomeratie, zo simpel is het. Verreweg de belangrijkste markten in onze samenleving zijn die voor arbeid, diensten en voorzieningen. Omdat juist deze markten frequente interacties veroorzaken en erg gevoelig zijn voor transportkosten zijn zij de primaire veroorzakers van stadsvorming. Maar zodra we ook maar één extra variabele of complicatie in zo'n model stoppen, zoals verschillende netwerken van infrastructuur, krijgen we wel meteen veel meer complexe uitkomsten die al veel minder lijken op

\section{De ranglijst van de economisch meest vitale daily urban systems zou wel eens aangevoerd kunnen worden door een Noord- Italiaanse groep gemeenten waar velen van ons nog nooit over hebben gehoord}

bolletjes. Als we vervolgens met ons model ook maar enigszins in de buurt zouden kunnen komen van het aantal variabelen en complicaties dat in de gemiddelde praktijk speelt krijgen we uitkomsten waarin we vrijwel geen bolletjes meer kunnen herkennen. De 


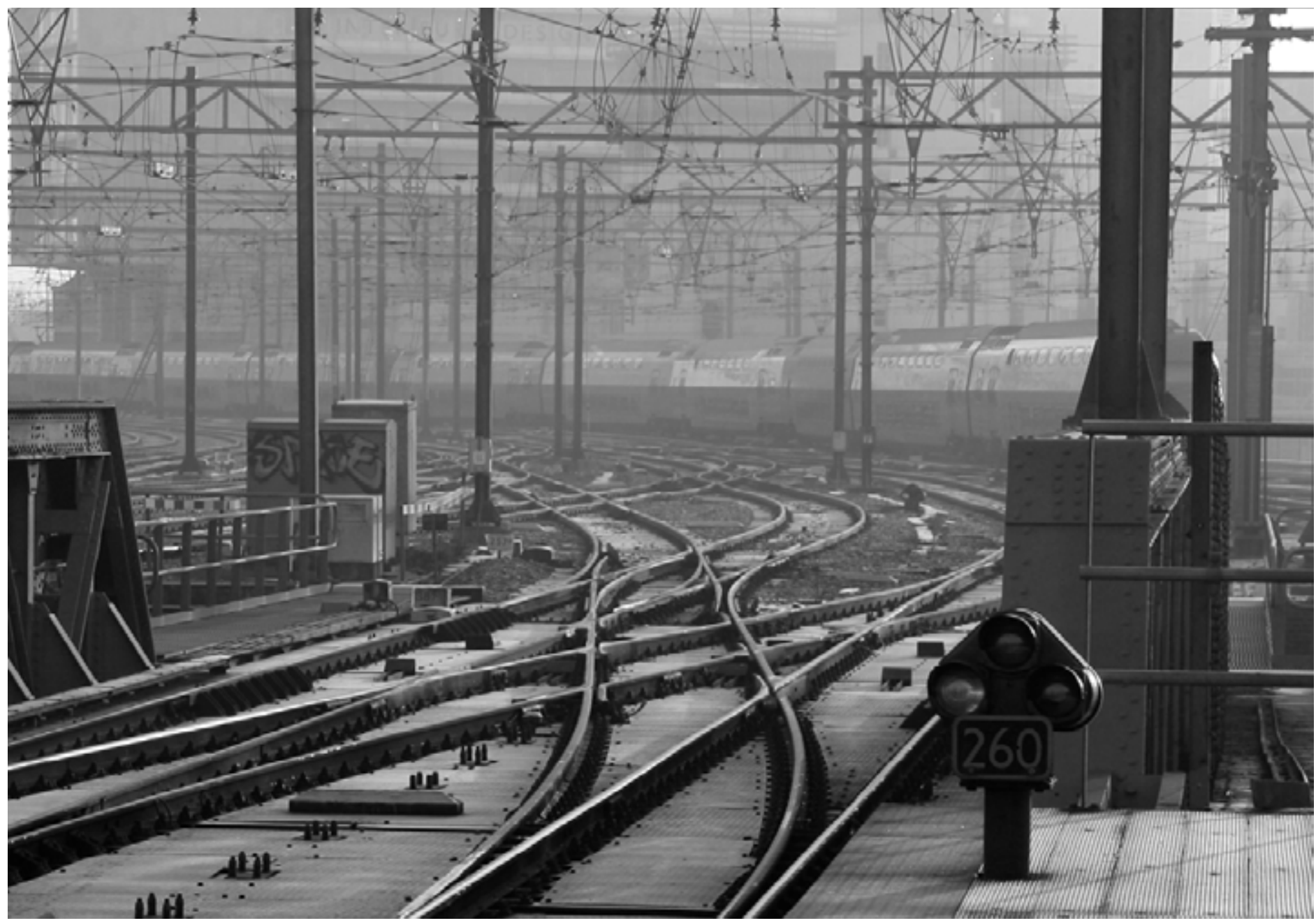

feitelijke verstedelijkingsstructuur functioneel bezien, is zeker in Nederland uiterst complex en veelgelaagd, en kan op geen enkele wijze worden gereduceerd tot een stelsel van afgebakende steden en netwerken tussen steden. De morfologische structuur laat nog wel klompachtige structuren zien, maar die hebben vooral een historische, toevallige of beleidsmatige achtergrond en vertellen ons weinig over feitelijke interacties, samenhang en de krachten in het spel. Met andere woorden, de morfologische klompen hebben occupaties maar beperkt in hun greep en spelen dus nauwelijks een eigenstandige rol, behalve dan waar een klomp toevallig samenvalt met gemeentegrenzen en aldus institutionele invloed uitoefent. Daarover zodadelijk meer.

\section{De agglomeratie als systeem}

Bolletjessteden zijn dus functioneel weinigzeggend, maar agglomeratiekrachten werken wel degelijk en geven verstedelijkingstructuren het karakter van economische deelsystemen. Als het aankomt op een serieuze verklaring spreken we in de stedelijke economie eerder over agglomeraties dan over steden. Agglomeraties zijn meestal meerkernig en hebben een natuurlijke neiging te groeien. Kort door de bocht verlaagt agglomeratie van activiteiten en factormarkten interactie- en transactiekosten, hetgeen tezamen met afstandsgevoelige positieve externe effecten en schaal- en netwerkeffecten zorgt voor hogere grondwaarden en welvaartsgroei. Die groei stimuleert verdere agglomeratie zodat een cumulatief causale spiraal ontstaat, ware het niet dat negatieve externe effecten zoals congestie een rem vormen die leidt tot evenwicht. Boven een bepaalde omvang is een meerkernige agglomeratie meer efficiënt dan een enkelkernige agglomeratie. Tot zover de theorie.

In de praktijk zijn de effecten van nabijheid, externaliteiten en netwerken dermate gedifferentieerd dat theoretische modellen nauwelijks rekenschap kunnen geven van de feitelijke complexiteit van verstedelijking en ruimtelijke interactiestructuren. Duidelijk is wel dat agglomeraties vooral worden gevormd door dagelijkse interacties, waarbij vooral de omvang van en variatie binnen de arbeidsmarkt en de dienstensector tellen. Het gevolg is een gestage ontwikkeling van daily urban systems met een grote economische diversiteit en geïntegreerde markten voor arbeid, diensten, huisvesting en voorzieningen. Hun fysieke omvang varieert van een half uur tot twee uur reisafstand. Functioneel gezien zouden we zo'n systeem als 'stad' kunnen beschouwen, in het volle besef dat ook uitgestrekte plattelandsgebieden zo'n systeem kunnen vormen. Daily urban systems kunnen morfologisch iedere mogelijke vorm aannemen. In feite is Nederland volledig bedekt met deze systemen, waarbij deze in veel gevallen bestaan uit een grote verzameling kleine en middelgrote kernen. Ranglijsten van steden zeggen daarom bijzonder weinig. De ranglijst van de economisch meest vitale daily urban systems zou wel eens aangevoerd kunnen worden door een 
Noord-Italiaanse groep gemeenten waar velen van ons nog nooit over hebben gehoord. Een uitgestrekte agglomeratie met congestievrije verbindingen en veel virtuele netwerken kan in principe groeikrachtiger zijn dan een hoogstedelijke agglomeratie met hoge dichtheid. Dit argument wordt door bekende wetenschappers als CPB directeur Coen Teulings c.s. en Edward Glaeser over het hoofd gezien in hun lofredes aan de stadseconomie. Het punt is door de auteur dezes onlangs naar voren gebracht waar het gaat om de economische vitaliteit en verstedelijkingsopties in Noord-Nederland. Bij dit alles moet worden opgemerkt dat over de feitelijke structuur en het functioneren van daily urban systems opvallend weinig bekend is.

\section{Veelgelaagde mozaïeken}

Met het begrip daily urban system komen we weliswaar verder, maar zijn we er nog lang niet. Om te beginnen behouden we een afbakeningsprobleem. De grote differentiatie in activiteiten en werkingssferen leidt immers tot complexe ruimtelijke gelaagdheid. Om daar een beeld van te krijgen heeft de auteur dezes eerder onderscheid gemaakt tussen daily urban systems, de werkingsfeer voor hoogfrequente interacties, en non-daily urban systems, de werkingssfeer voor minder frequente interacties en voorzieningen in de hoogste regionen van de hiërarchie. Zo kan geheel Nederland worden gezien als een non-daily urban system, dat draagvlak geeft voor bijvoorbeeld Schiphol. Maar ook dit en ieder ander onderscheid in ruimtelijke schaalniveaus blijft arbitrair. Voor breed gedeelde voorzieningen en markten zoals die voor huisvesting kan een agglomeratie als gebied nog een zekere systemische samenhang kennen, maar voor meer specifieke (markt-)relaties is het agglomeratiebegrip als snel überhaupt niet meer zo relevant. Agglomeraties zijn niet alleen een daily urban system maar vormen ook een verzameling locaties en losstaande occupaties die ieder op andere manieren met de wereld zijn verbonden. We kunnen een zekere analogie vinden in de tweedeling naar zwakke en sterke krachten in de fysica. De graviteit van het daily urban system is een zwakke kracht die voor de meeste occupaties geldt, maar daarnaast zijn occupaties ruimtelijk onderhevig aan specifieke, sterke krachten die op geheel andere niveaus kunnen werken, lokaal, internationaal, of allebei tegelijk. Zo is de Amsterdamse Zuidas in veel opzichten sterker verbonden met de Londense City dan met het in dezelfde agglomeratie gelegen Zaanstad. De grote variatie in activiteiten en verbindingen, gepaard aan uitsorteringsverschijnselen, geven agglomeraties het karakter van een mozaïek van locaties en overlappende netwerken die onderling slechts een zwakke band hebben. Een voorbeeld hoe dit uitpakt voor Amsterdam. De noordelijke IJ-oevers zijn populair bij de creatieve klasse. Klanten en relaties zitten in de grachtengordel, op de Zuidas, in Rotterdam en Londen. Met de rest van Amsterdam-Noord is nauwelijks enige relatie. De economische en sociale beweging van Amsterdam-Noord moet uit een geheel andere (netwerk-)context worden verklaard. Door de toenemende specialisatie en complexiteit in economie en samenleving worden (wat we hier betitelen als) sterke krachten

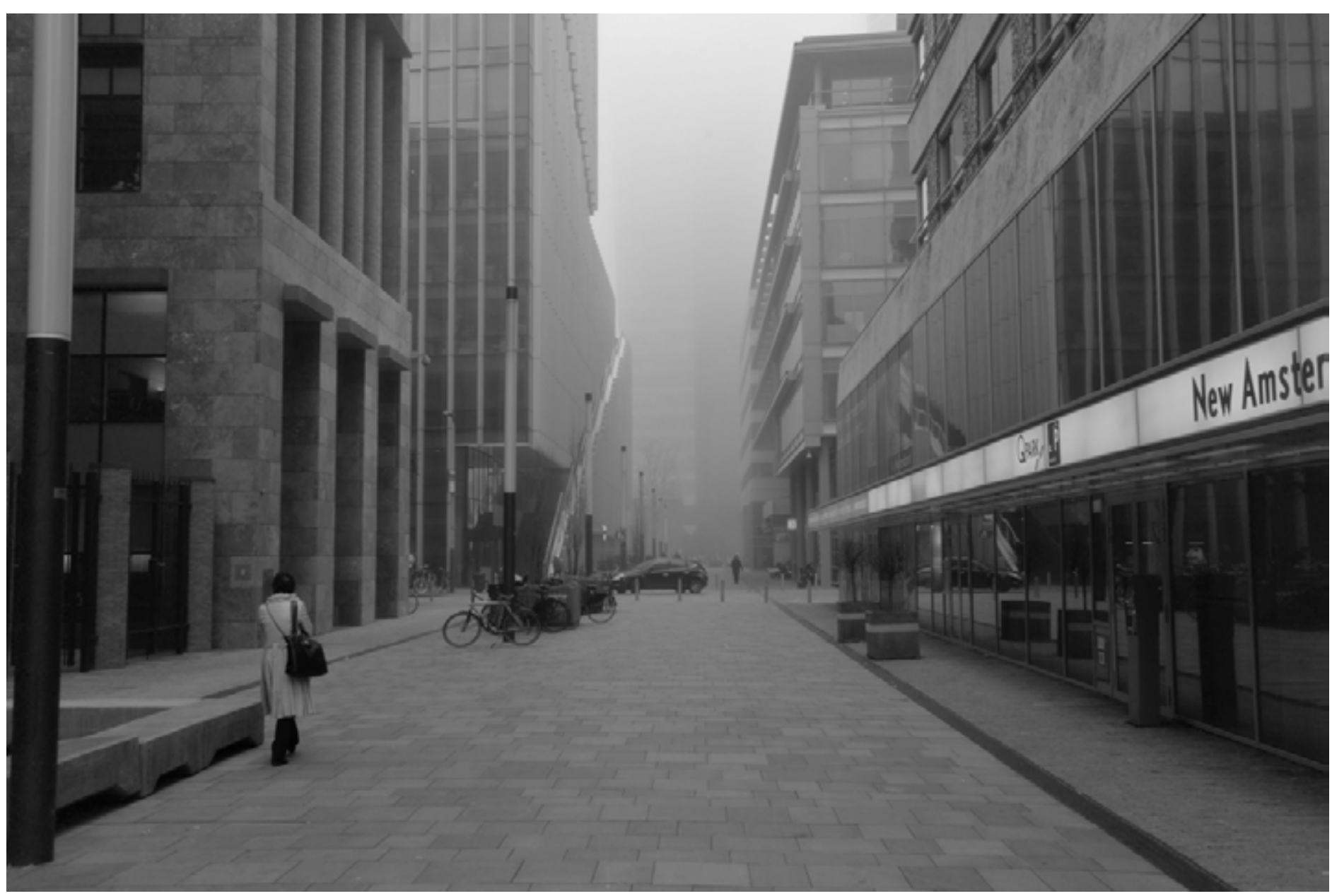


waarschijnlijk belangrijker, ten detrimente van de zwakke, algemeenagglomererende krachten. Het gevolg kan zijn dat de moderne agglomeratie als morfologisch systeem de aloude stad achterna gaat: ook de agglomeratie ontrafelt en wordt als begrip steeds minder bruikbaar om verstedelijking te begrijpen.

\section{De stad als actor}

Maar de stad is natuurlijk niet alleen een morfologisch begrip. Als we in Nederland van 'de grote steden' spreken bedoelen we meestal de in inwonertal grote gemeenten. Economie en samenleving van die steden hebben zoals gesteld weinig systemische samenhang, maar het stadsbestuur heeft wel macht en invloed die scherp zijn bepaald door het door gemeentegrenzen afgebakende gebied. Nobelprijswinnaar Paul Krugman stelt dat steden niet concurreren; alleen bedrijven doen dat. Als gemeente concurreren steden echter wel degelijk, bijvoorbeeld met financiële prikkels om bedrijven binnen te halen. Deze institutionele invalshoek op het bestaan van steden biedt uiteraard veel stof ter overdenking. We beperken ons hier tot de vraag of de gemeentelijke macht en invloed ook samenhang (terug)brengen binnen de gemeentegrenzen, gegeven dat 'de stad' als begrip toch vooral staat voor gebiedsgerichte samenhang. Samenhang wordt immers ook beoogd door menig stadsbestuurder. Stadsbestuurders hebben echter van doen met een fundamenteel probleem. Hun beleidsinvloed is vooral gebaseerd op reeds bestaande gebiedsgerichte samenhang. Immers, hoe meer gebiedsgerichte samenhang, hoe meer sturingsmogelijkheden en hoe groter de vliegwieleffecten van publieke investeringen. Het is echter moeilijk zo niet onmogelijk om gebiedsgerichte samenhang met beleid te creëren waar die niet al vanzelf, gedreven door marktkrachten, ontstaat. Hoogstens kunnen marktpotenties met beleid wat eerder of wat beter worden benut. De markt werkt op zich vooral functionele stadsontrafeling in de hand. Als die ontrafeling er eenmaal is kan gebiedsgericht beleid snel averechts gaan werken. Gemeenten spelen het slimmer als ze hun beleid op regionaal (agglomeratie-)niveau afstemmen. Vaak komt dan de discussie op hoe groot de bestuurlijke regio dan moet zijn, wie wel en wie niet moeten meedoen. Functioneel gezien maakt dat uiteraard wel wat uit, maar ook weer niet zo heel erg veel, want er kan zoals zojuist besproken vanuit functioneel perspectief überhaupt geen 'optimale' omvang van de regio worden bepaald. Vaak ook wordt verondersteld dat het bij regionale afstemming vooral om gemeenschappelijke belangen moet spelen. Dat is niet zo. Het maakt niet uit of de gemeentelijke belangen binnen een agglomeratieverband worden gedeeld of niet. Belangen kunnen gerust conflicterend zijn. Waar het slechts om gaat is dat in ieder geval wordt ingespeeld op de functionele, economische en maatschappelijke samenhang binnen de agglomeratie. Alleen dan gaat beleid werken. Conflicterende belangen kunnen vervolgens samen met andere belangen in een mandje worden gelegd en onderling worden uitgeruild. Zolang er over het geheel maar winst valt te halen.

Gemeenten spelen het tenslotte het slimste als ze, naast beleidsafstemming in agglomeratieverband, ook nog eens beleid afstemmen in sterke grensdoorsnijdende verbanden waarin activiteiten zijn gebed. Gemeenten kunnen aldus trachten enige greep te krijgen op de netwerkmozaïeken waarbinnen economie en samenleving werken. Alleen dan komen de institutionele netwerken in de buurt van de feitelijke functionele structuur van de verstedelijking en kan beleid echt haar werk gaan doen. Het maakt het werk van de bestuurder zeker niet gemakkelijker.

\section{De stad als interpretatie}

De stad bestaat misschien niet (meer) in het echt, maar zit nog wel tussen onze oren. Het gaat dan om persoonlijke, al of niet groepsgebonden interpretaties van de stad. We zijn vervolgens vooral benieuwd of deze interpretaties, naast de bovenbeschreven krachten, hun eigen invloed hebben op de feitelijke structuur van de verstedelijking. Daarmee komen we overigens ook weer op het terrein van beleid. Beleid wordt immers mede ingegeven door gedeelde ideaalbeelden, zeker op het vlak van stedenbouw en ruimtelijke ordening.

\section{Straten in de slaperige Amsterdamse buitenwijk Buitenveldert zitten vol met zowel mensen die de stad zijn ontvlucht als mensen die juist graag in de stad wonen}

Allereerst kunnen we op borrels en feestjes, waar sympathieën en antipathieën jegens 'de stad' een geliefd gespreksonderwerp zijn, constateren dat persoonlijke stadsinterpretaties sterk kunnen verschillen. Straten in de slaperige Amsterdamse buitenwijk Buitenveldert zitten vol met zowel mensen die de stad zijn ontvlucht als mensen die juist graag in de stad wonen. Verschillende interpretaties kunnen tot gelijkgericht handelen leiden. De stad als fenomenologisch verschijnsel heeft in zoverre maar beperkte invloed op de feitelijke verstedelijking. Maar interpretaties zijn ook groepsverschijnselen die grote invloed kunnen hebben. Het beeld van de ideale stad zoals Richard Florida dat oproept is populair bij de 'creatieve klasse' en de ontwikkelaars die zich ook die markt richten. Die populariteit speelt specifieke delen van grootstedelijke agglomeraties in de kaart, waaronder vooral hoogstedelijke locaties met veel transformatiemogelijkheden. Gegeven de reislustigheid van kosmopolitische creatieven kunnen relaties tussen hippe locaties in verschillende agglomeraties vervolgens veel belangrijker worden dan de relaties tussen zo'n locatie en de naastgelegen stedelijke omgeving. Zo komen we toch weer uit op het netwerkmozaïek, en niet op een renaissance van 'de stad'.

Nog krachtiger wordt de invloed van interpretaties als deze gecombineerd werken met institutionele mechanismen en aldus het beleid voeden. We zijn dan vooral benieuwd naar stadsinterpretaties van invloedrijke professionals, waaronder stedenbouwers en planologen. We komen dan op het terrein van planningdoctrines. Paul Krugman 
kan met behulp van geavanceerde ruimtelijk-economische modellen en een flinke dosis historische verklaring redelijk zinnige dingen stellen over de Noord-Amerikaanse morfologische verstedelijkingstructuur, maar zal in de Nederlandse situatie eerst en vooral te rade moeten gaan bij ideeën en doctrines van stedenbouwers, planologen en ruimtelijke beleidsmakers.

Dit vereist een geheel ander soort onderzoek. De stedelijke morfologie in Nederland is immers sterk bepaald door opvattingen die deze groepen hebben over de functies van 'de stad'. Die opvattingen gaan verder dan beeldvorming en zijn vaak gedreven door geografisch-institutionele constellaties en de belangenstrijd die in dat kader speelt. Besturen in de grote gemeenten hadden in de afgelopen halve eeuw overwegend een progressief-liberale samenstelling, suburbane gemeenten een conservatief-liberale snit en kleine plattelandsgemeenten een conservatief-confessionele achtergrond. In zo'n situatie liggen de belangen van grote en dichtbevolkte gemeenten, die niet kunnen uitbreiden maar wel groe van bevolking en economie willen, in het verlengde van conserverende belangen in rijke suburbane gemeenten en dun(ner)bevolkte gebieden. Het stad-land discours en de ideaalbeelden van een mooi open land, de pionierende groene groeistad en het creatieve hoogstedelijke centrum, die zo typisch zijn voor de professionele $\mathrm{RO}$-praktijk in Nederland, zijn instrumenteel in dit belangenspel. ledereen heeft belang bij steeds dichter bevolkte hoogstedelijke gemeenten, maar die mogen het land niet te zeer gaan domineren. Collectief schrikbeeld was en is nog altijd is de vervaging van grenzen tussen stad en land en amorfe verstedelijking zoals we die zien in de V.S. De verstedelijkingsstructuur van Nederland en de in de afgelopen halve eeuw dominerende planningdoctrines kunnen daarom worden gezien als de uitkomst van een maatschappelijk contract. Fundamentele achtergrond is een situatie van langdurige groei en een naar internationale maatstaven gemeten machtige gemeentelijke overheid die moet opereren binnen vastgeroeste bestuurlijke grenzen. Opeenvolgende planningdoctrines van gebundelde deconcentratie, stedelijke verdichting en transformatie, ieder voortkomend uit het bovenbeschreven maatschappelijke contract, hebben sterk bijgedragen aan het behoud en de vorming van de, in internationaal perspectief bezien relatief sterke, morfologische structuur van occupaties in Nederland. Het gaat echter vooral om een fysiek decor, zo is hier de stelling. Planningdoctrines droegen bij aan relatief grote verschillen in fysieke dichtheid of 'stedelijkheid', maar binnen dit fysieke decor strekt de verstedelijking als functioneel, economisch, sociaal en cultureel verschijnsel zich over het gehele land uit, over stad en platteland. De mentale fixatie van planners die leidt tot de stad als decor. Nu nog goede plannen voor de verstedelijking van het echte leven. Dat kunnen we niet alleen aan het spel van de vrije markt overlaten.
Pieter Tordoir is als hoogleraar Economische Geografie en Planologie verbonden aan de Universiteit van Amsterdam en aan de Amsterdam School of Real Estate. Daarnaast drijft hij een praktijk voor onderzoek en advies, Ruimtelijk Economisch Atelier Tordoir, en bekleedt hij verschillende bestuurlijke en adviserende functies in de sfeer van stedelijke ontwikkeling en ruimtelijke ordening.

Literatuurselectie

Anas, A., R. Arnott \& K. Small (1998), 'Urban Spatial Structure', in: Journal of Economic Literature, Vol. XXXVI (september 1998), pp. 1426-1446.

Glaeser, E. (1998), 'Are Cities Dying', in: Journal of Economic Perspectives, Vol. 12, pp. 139-169.

Groot, H. de, G. Marlet, C, Teulings \& W. Vermeulen (2010), Stad en Land. Den Haag: Centraal Planbureau.

Krugman, P. (1997), Development, Geography, and Economic Theory. Cambridge (Mass.): The MIT Press.

Tordoir, P.P. (2001), Marktwerking en ruimtelijke organisatie: Catch-22 of creatieve spanning? Oratie, Amsterdam: Vossiuspers UvA.

Tordoir, P.P. (2005), Stad en Welvaart. Beleid voor de nieuwe stedelijke economie. Netherlands Institute for City Innovation Studies, Den Haag.

Tordoir, P.P. (2010), Noorderlicht. Ruimtelijk economisch toekomstperspectief voor Noord-Nederland. Groningen: Kamer van Koophandel Noord-Nederland. 


\section{Espressocultuur in plaats van rechtvaardige steden}

AUTEUR \& FOTOGRAFIE Yvonne Rijpers

\section{Naar aanleiding van haar boek 'Naked City' en haar verblijf in Amsterdam, sprak AGORA met Sharon Zukin. Over haar boek, haar visie en haar doelgroep. Een interview, interessant vanwege haar inhoude- lijke werk, maar ook om wat Zukin impliciet en expliciet te melden heeft over hypes en haar eigen rol daarin.}

Sharon Zukin is professor Sociologie aan Brooklyn College en het Graduate Centre van de City University of New York. Onderwerpen waar ze zich mee bezighoudt zijn cultuur en vastgoed in New York, culturele productie en consumptie, het veranderen van de stad door de-industrialisatie, gentrificatie en immigratie. Ze is bekend van haar boeken 'Loft Living' en 'The Cultures of Cities'. 'Naked City, the death and life of authentic urban places', is haar laatst verschenen boek. De achterflap van het boek belooft een "essentieel kompas voor mensen die worstelen met de kracht van het hedendaagse kapitalisme in hun dagelijkse omgeving". Een kompas is het echter niet, alleen al omdat het kernbegrip van het boek - authenticiteit veel te diffuus is om houvast aan te bieden.

Voor hedendaagse, gegentrificeerde stedelingen, staat authenticiteit gelijk aan zaken zoals oude gebouwen, galerieën, boetiekjes,

traiteurs, biologische markten, koffietentjes en etnische restaurantjes. Zukin beschrijft het als een totaalsfeer, een beleving van een plek die samenhangt met wat die plek te bieden heeft; zoals de bebouwde omgeving, het soort gebruikers, het gevoel van veiligheid, het soort winkels en ander vrijetijdsaanbod. Volgens haar neemt de vraag naar authenticiteit wereldwijd toe, wat zich uit in een opschaling van wijken (gentrificering) en escalerende vastgoedprijzen. Tegelijkertijd zorgt dit ervoor dat de mensen die deze wijken hun aantrekkelijke authenticiteit geven, weggejaagd worden omdat het te duur voor ze wordt om te blijven. Aan de hand van verschillende voorbeelden op verschillende plekken in New York doet Zukin uit de doeken hoe dit proces werkt, of eigenlijk niet werkt, aangezien de begeerde authenticiteit verjaagd wordt samen met de mensen die de wijk authentiek maken.

\section{Vocabulaire van de straat}

Authenticiteit is een moeilijk in te kaderen wetenschappelijk concept. Zukin noemt het zelf elitair, chaotisch, normatief en empirisch. Kortom, een gek concept. Mensen om haar heen verklaarden haar voor gek dat ze over een dergelijk concept wilde schrijven en publiceren. Echter, het is een concept dat tot het hedendaagse vocabulaire behoort en volgens haar daarom juist geschikt om te gebruiken. Ze vertelt dat de term zo alomtegenwoordig is, dat de woorden authenticiteit en espresso cafés, ook bij haar Afro-Amerikaanse studenten uit wijken met lage huren een belletje doet rinkelen. Ook in hun voorheen homogene wijken zien zij blanke mensen joggen en andere voorzieningen verschijnen. Ze zien hun wijken verkleuren, verhippen en duurder worden; de plaatselijke kleine supermarkten verdwijnen, koffiebars en delicatessenzaken verschijnen. Dit is het effect van de vraag naar authenticiteit en dit zijn de voorbeelden die volgens Zukin iedere stedeling onmiddellijk begrijpt. "Ik probeer me te richten op de mensen die het woord authenticiteit al gebruiken. Tegen hen zeg ik: laten we het hebben over wijken en steden, met dit vocabulaire. En als je op deze manier kijkt, wat is dan een authentieke wijk? En als je op zoek bent naar authenticiteit, is het dan niet zo dat je de kans loopt om authenticiteit de das om te doen, omdat je naar een wijk verhuist terwijl de authentieke mensen daar wegtrekken? Ik probeer dit soort spanning aan he $\mathrm{t}$ licht te brengen in het boek."

\section{Engagement}

Naked city is een geëngageerd boek dat burgers bewust wil maken en als het even kan veranderingen teweeg wil brengen. Zelf zegt Zukin wetten van steden zoals New York te willen aanpassen zodat 
mensen, zowel bewoners als winkeliers, niet weggejaagd worden uit hun buurt, maar de kans krijgen om te blijven waar ze willen blijven. Met het boek richt ze zich tot beleidsmakers en mensen uit de 'hogere middenklasse' waartoe ze ook zichzelf rekent; vaak dezelfde personen die gentrifiers zijn. Het proces van gentrificatie en herontwikkeling dat de laatste twintig tot dertig jaar in New York plaatsvindt, het 'opschalen van buurten' zoals ze dat noemt, kenschetst ze als een continue verandering naar een postindustriële economie. Een economie die geen plek heeft voor mensen met die vooral met hun handen werken. Stedelijke centra worden weer eigendom van de rijkere mensen, de hogere middenklasse. Zukin wil bij haar lezers de bewustwording creëren wat het effect is van authenticiteit. Ze wil dat ze beseffen dat de smaak van gentrifiers (de hogere middenklasse en hopelijk ook haar leespubliek), in culturele goederen en stedelijke omgevingen het effect heeft dat bepaalde mensen weggejaagd worden. "Mijn boek levert een bijdrage aan het bestuderen van steden door te zeggen: ja, we moeten kijken naar kapitaal en nationaal beleid, maar we moeten ook kijken naar consumentencultuur en de media - die niet zelf dingen creëren, maar wel drijvers zijn van veel van deze veranderingen."

\section{Wetenschappelijke concepten zijn voor Zukin niet sexy genoeg om haar boodschap over te brengen}

\section{Een hype-boek?}

Door aan te sluiten bij het vocabulaire van de straat, maakt Zukin een duidelijke keuze; een keuze tegen het wetenschappelijke discours en voor het bereik van een groter, niet-wetenschappelijk publiek. Een gedurfde keus, waarmee Zukin zich in zekere zin schaart bij de Richard Florida's van de wetenschappelijke wereld. Zelf noemt ze het liever een artistieke beslissing, omdat ze mensen probeert te bereiken vanuit hun eigen referentiekader om ze van daaruit mee te nemen, in plaats van ze proberen te dwingen haar gedachtelijn te volgen. Zukin maakt echter niet alleen de keuze voor een bepaald discours, ze maakt ook de keuze voor een bepaalde opbouw en uitwerking van haar boek, gericht op een bepaald publiek en met een doel - de stedeling aanzetten tot verandering - dat afwijkt van het wetenschappelijk niveau dat je van haar zou verwachten. Inderdaad, Naked City is toegankelijk, begrijpelijk en met taal en voorbeelden die de hedendaagse stedeling moeiteloos begrijpt. Dit heeft als gevolg dat het boek leunt op een dun wetenschappelijk kader, erg veel beschrijvingen en heeft amper eenduidige conclusies. In plaats van dat Zukin iets onderzoekt, een patroon ontdekt, een mogelijke oplossingsrichting aandraagt of conclusie trekt, blijkt dat ze het zelf eigenlijk ook niet zo goed weet. Dit geeft ze ook meermalen aan in het gesprek; de vraag omtrent authenticiteit en de rechtvaardige stad blijft een dagelijkse worsteling tussen wat belangrijk is voor een individu (in deze de gentrifiers) en wat in breder maatschappelijk oogpunt wenselijk is. En ook over dat laatste is uiteraard geen consensus.

Waarom is dit boek dan toch van waarde? Omdat het inderdaad wel degelijk doet wat Zukin beoogt: aanzetten tot denken en een heroverweging van de eigen keuzes, wensen en voorkeuren. De uit het dagelijks leven geplukte voorbeelden zijn weliswaar allemaal gesitueerd in New York, maar grotendeels verplaatsbaar naar de West-Europese stedelijke omgeving. Kleine ondernemers verdwijnen overal ter wereld in 'opkomende' wijken, ten koste van yoghurtbars, koffietentjes, of hippe designerwinkels, vaak met lokale subsidie opgezet om de wijk een duwtje te geven. En inderdaad is het niet altijd fijn om na te denken wat er met de oorspronkelijke ondernemers en bewoners gebeurt als een wijk gentrificeert. Zet het boek dan ook echt aan tot actie? Dat wellicht niet altijd, maar het aan het licht brengen van deze 'ongemakkelijke waarheid' is al een goede eerste stap.

\section{Strijd om ruimte}

Zukin zegt niet geïnteresseerd te zijn om nog meer te schrijven over 'rechtvaardige steden', een discours dat volgens haar maar een bepaalde groep mensen aanspreekt en zeker niet de meerderheid van de bevolking die zij aan wil spreken. Toch gaat het boek wel degelijk over 'rechtvaardigheid'. Sterker nog, volgens Zukin gaat alle urbane wetenschap over democratie en gelijkheid. "Veel vrienden en collega's noemen deze periode een van liberalisme en revanchisme. Ik denk dat revanchisme een te sterke term is, maar feit is dat we zien dat de stedelijke centra weer eigendom worden van de rijke mensen, niet de armere mensen. Het is een situatie met meerdere kanten, maar wel een situatie waar rijkere mensen meer baat bij hebben dan armere."

De queeste naar authenticiteit en een authentieke stad komen uiteindelijk neer op de vraag wat een rechtvaardige stad is en wie er het recht op een (plek in) de stad heeft. Dit is een constant gevecht, tussen verschillende (groepen) gebruikers, ontwikkelaars en diverse andere actoren. Het recht op een stad is volgens haar het recht om op een plek te zijn, zo lang je geen wetten overtreedt en niet de behoeften van een ander schendt - een dunne scheidslijn, want behoeftes verschillen van elkaar en bijten elkaar. Ze neemt Union Square als voorbeeld: een voorheen rommelig en onveilig plein, dat opgeknapt is sinds het onderdeel is van een BID (Business Improvement District).

"Ik voel de paradox als ik er loop, want dan vind ik dat er teveel verkopers zijn, overal, ze drukken het publiek weg, nemen de plek over van mij als consument. Wat voor de ene teveel en te druk is, is voor de ander levendig. Het is een constante strijd om democratische manieren te vinden om het gebruik van openbare ruimte te verdelen. De stad is een arena van strijd - tussen producenten en consumenten van openbare ruimte - om onze behoeften met elkaar in balans te brengen."

\section{Jane Jacobs}

Naked City is ook een expliciete kritiek op (de uitwerking van) het gedachtegoed van Jane Jacobs, een andere auteur die het is gelukt 


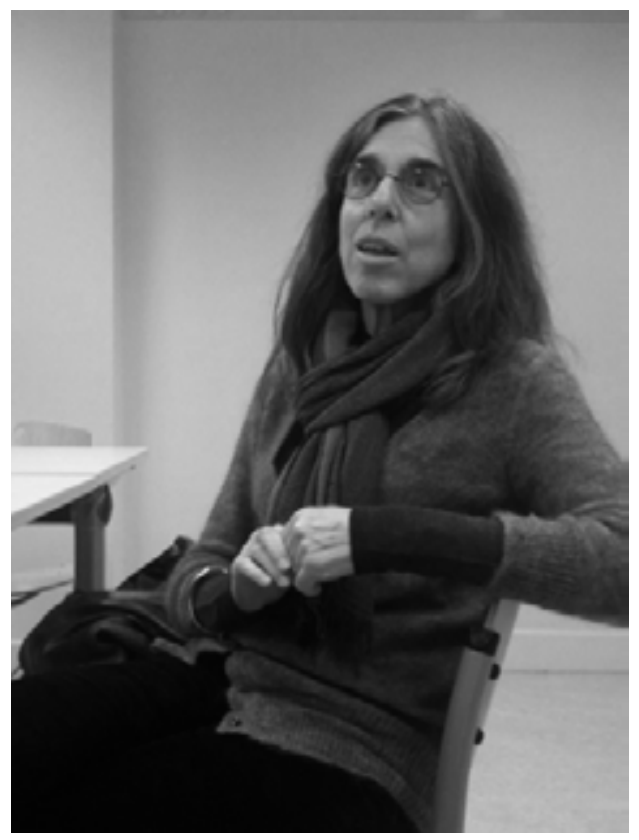

Sharon Zukin in gesprek met AGORA

aan te zetten tot actie. Jane Jacobs, activiste en publiciste heeft zowel in de wetenschap en de praktijk een stroming (New Urbanism) op gang gebracht en is in de hedendaagse planologie nog steeds invloedrijk. Zeker in New York, haar bakermat en ook het domein van het boek van Zukin. Zo steunt de City Planning Commission van New York in de geest van Jacobs veranderingen in zonering beleid (een van de belangrijkste planologische instrumenten in New York) waardoor de kleine schaal van vele straten worden behouden. Tegelijkertijd steunt de commissie de verlangens van de burgemeester om groei te bevorderen in de stad door de zonering van de grote straten te verruimen. Hier worden dan hoge nieuwe gebouwen mogelijk, terwijl de kleinschaligheid van de zijstraten behouden blijft. Dit verhoogt de vastgoedwaarde op twee manieren. Enerzijds door behoud van de laagbouw in de zijstraten voor de gentrifiers die oude huizen willen kopen, anderzijds doordat ontwikkelaars nieuwe hoogbouw in grote straten kunnen bouwen. Zukin merkt op dat er zo 'virtuele authenticiteit' wordt gecreëerd; men kan genieten van de mooie zijstraten met hun laagbouw. Echter, dit beleid van behoud van het oude en elders ruimte scheppen voor het nieuwe, is puur gericht op gebouwen. Het houdt geen rekening met wat er in de gebouwen gebeurt, wie er wonen, wie de gebruikers zijn. Jacobs hangt volgens Zukin een romantisch ideaal van New York en het New Yorkse leven aan, dat ontzettend tijdsgebonden is. Omdat Jacobs haar eigen buurt en beleving in de jaren '50 beschreef, was Jacobs zich niet bewust van haar beperkte, tijd- en plaatsgebonden referentiekader. De mensen, bewoners, winkeliers, gebruikers, om haar heen waren zo vanzelfsprekend, dat ze haar aandacht vooral richtte op de bebouwde omgeving en de veranderingen daarin. De authenticiteit die ook Jacobs zo pakkend beschrijft, hangt niet alleen af van de bebouwde omgeving, maar ook - en misschien wel vooral - van een economische en sociaal diverse bevolking en houdt alle dingen in, die vernietigd worden als de prijs van het vastgoed stijgt. Ook Jacobs haar volgelingen - onder wie vele beleidsmakers - hebben volgens Zukin deze blinde vlek voor de mensen die de authen- tieke sfeer bepalen, en zijn veel teveel gericht op virtuele authenticiteit.

\section{Hypes}

Zukin speelt met haar boek in op de overtuigingskracht van ruimtelijke hypes op het beleid, zowel in de keuze van het onderwerp en het daaraan verwante taalgebruik. Wetenschap en wetenschappelijke concepten zijn voor haar blijkbaar niet sexy genoeg om haar boodschap over te brengen. Daarom wendt ze zich tot de populaire cultuur om de mensen op straat te bereiken. Wat ze wil (en ook impliciet toegeeft) is zelf een hype tot verandering creëren, door het meeliften op dit hedendaagse taalgebruik en deze hedendaagse wensen en concepten. Met het vocabulaire van de straat, speelt Zukin in op trends in de samenleving. Niet de creatieve klasse, of rechtvaardige steden, maar authenticiteit moet de aandacht krijgen van burgers en beleidsmakers, net als 'walkability' die aandacht kreeg na Jacobs' interventie. Haar doel en middel om dit te bereiken zijn zeker te waarderen, het is alleen de vraag of het de taak van wetenschappers is om zich hiervoor te lenen, omdat het in dit geval ten koste van het wetenschappelijk gehalte van het boek gaat. . Wat zegt dit over haar wetenschapsopvatting? En is er iets voor te zeggen om het wetenschappelijk gehalte van een boek op te offeren ten behoeve van het bereiken van een groter publiek? Is het niet cynisch om ervan uit te gaan dat wetenschap niet het bereik heeft om echt iets voor elkaar te krijgen in de wereld? En is Richard Florida niet het bewijs dat je met populair wetenschappelijke taal en concepten een heel eind kan komen in de wereld en ook echt verandering teweeg kan brengen? Zelf merkt Zukin hierover op dat veel beleidsmakers verblind zijn door zijn 'retoriek' over de creatieve klasse. Eigenlijk eenzelfde verwijt dat ze maakt over de retoriek van Jacobs. Maar waarin verschilt haar eigen retoriek over authenticiteit dan?

Sharon Zukin lijkt op een hype mee te liften. Het begint een trend onder wetenschappers te worden om zich meer op de markt te richten, de wetenschap te laten voor wat het is en ten koste van wetenschappelijke precisie zich op een ander, breder publiek te richten. Buigen wetenschappers voor hippe termen, voor de taal van het volk, en gooien ze de wetenschap in de uitverkoop? Als dat inderdaad een hype is, is het er een die Zukin goed heeft begrepen; ze omhelst de espressocultuur en laat het rechtvaardigheidsjargon in de universiteit achter. Voor Zukin heiligt het doel de middelen. Als de wetenschap 'sexy' en vluchtiger moet op opdat er een groter publiek wordt bereikt, dan moet dat maar.

\section{Yvonne Rijpers (ymrijpers@gmail.com) is zelfstandig adviseur stedelijke ontwikkeling en coördinator bij de Vereniging Delta- metropool. Ze is tevens redacteur van AGORA.}

Literatuurselectie

Jacobs, J. (1961), The death and life of great American cities. New York: Random house.

Zukin, S. (2010), Naked city: the death and life of authentic urban places. Oxford: Oxford University Press. 


\section{De creatieve hype}

AUTEURS Marco Bontje \& Peter Pelzer

FOTOGRAFIE Marco Bontje \& Bas Czerwinski

Tien jaar na dato lijkt de hype rond The Rise of the Creative Class een beetje te zijn gaan liggen. Tijd voor een reconstructie. Het is de vraag of de karrenvracht aan kritiek op Richard Florida gelijke tred houdt met zijn invloed op ruimtelijk beleid. Wellicht is ook hier sprake van een hype.

\section{De creatieve stad}

In het begin van dit millennium nam het economische discours over steden een nieuwe wending. Steden veranderden niet zozeer radicaal -de veranderingen waren al decennia eerder ingezet en opgemerkt- maar een nieuwe verklaring voor economisch succes raakte in zwang: de creatieve stad. Met name Richard Florida ontpopte zich als boegbeeld van de creatieve klasse. Van zijn boek The Rise of the Creative Class werden wereldwijd honderdduizenden exemplaren verkocht. Dit succes kan voor een deel worden toegeschreven aan de persoon Richard Florida zelf. Losjes, welbespraakt en altijd in de hipste kostuums. De verpersoonlijking van zijn zelfgeschapen paradigma. Niet verwondelijk dat hij een verpletterende indruk maakte in de Amsterdamse Westergasfabriek, tijdens zijn bezoek aan Nederland in 2003. Geen nuffige wetenschapper van mitsen en maren, maar een bevlogen spreker met heldere oplossingen. Zijn betoog in een notendop: steden die aantrekkelijk zijn voor creatief talent groeien het hardst; en om dat creatieve talent te trekken heb je een tolerante, diverse en levendige stad nodig. 'Werk volgt talent' in plaats van 'talent volgt werk'. Voor stedelijke overheden was dit een welkome boodschap: een positief verhaal over stedelijkheid en functiemenging, daar konden beleidsmakers wel iets mee. Ook studenten stortten zich massaal op de creatieve klasse. De vele scripties over culturele broedplaatsen, kunstwerelden en creatieve clusters zijn vaker herhalingen van zetten, dan dat ze veel nieuwe inzichten toevoegen. Het thema trekt vaak meer omdat het trendy is, dan dat studenten willen uitzoeken of Florida nu echt gelijk heeft. Je mengen onder geestverwanten is klaarblijkelijk aantrekkelijker dan veldwerk in achterstandswijken.

\section{Kritiek}

Ondanks, of misschien juist dankzij zijn populariteit, werd Florida hevig bekritiseerd vanuit de wetenschap. Zijn statistieken deugden niet, de causaliteit rammelde en het creatieve klasse begrip was conceptueel slordig, om een paar voorbeelden te noemen. In dit artikel ligt de nadruk echter minder op Florida de wetenschapper maar meer op Florida de consultant. De hype omtrent de creatieve klasse ontstond niet zozeer omdat er zulke baanbrekende inzichten werden gepresenteerd - Jane Jacobs verkondigde in de jaren zestig al een vergelijkbaar verhaal over stedelijkheid en diversiteit - maar vooral door de manier waarop deze gepresenteerd werden: vlot en eenvoudig opgeschreven en met heldere beleidsadviezen. Florida's naam zoemt dan ook in vele Europese steden rond aan het begin van dit millennium. Zijn bijbel zou op het nachtkastje van iedere beleidsmaker liggen. Is dit nu de man die de ruimtelijke ordening na Van Eesteren, Le Corbusier en Jane Jacobs opnieuw op zijn kop gaat zetten? Jamie Peck vond Florida in ieder geval belangrijk genoeg om hem in zijn artikel 'Struggling with the Creative Class' op spottende toon aan te pakken. De inzichten van Florida bieden een excuus om duur en zwaarwegend beleid zoals inkomenspolitiek in te ruilen voor relatief gemakkelijk en goedkope ingrepen, zoals het aanleggen van fietspaden. Een neoliberale agenda in een designerjasje.

\section{Een hype?}

ledereen is het er inmiddels wel over eens dat creativiteit in het begin van dit decennium, net als globalisering in de jaren negentig, een modewoord was dat te pas en vooral te onpas gebruikt werd. Dit heeft sociale wetenschappers er niet van weerhouden om activisten te waarschuwen tegen het gevaar dat Florida heet. In 


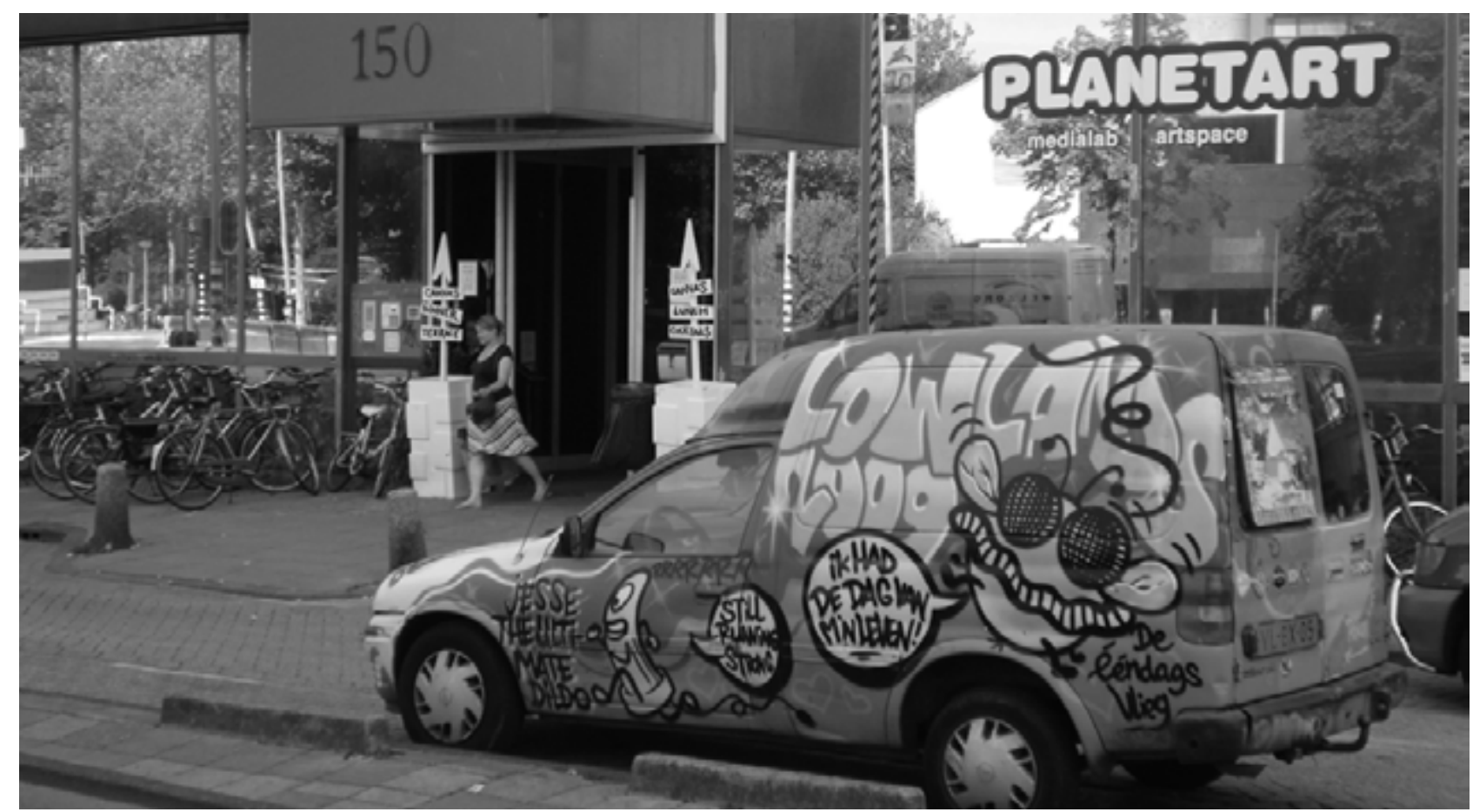

Het creatief hergebruik van het Volkskrant gebouw in Amsterdam past naadloos in Florida's creativiteitsdiscours

wetenschappelijke tijdschriften kon je gemakkelijk twee vliegen in een klap slaan. Ten eerste is de creatieve klasse theorie dusdanig precies en grofmazig tegelijkertijd dat er altijd wel een extra kritiekpuntje was te maken. Tegenover het vrij slordige gebruik van het begrip 'klasse' staan bijvoorbeeld zeer precieze aanbevelingen voor beleidsmakers. Ten tweede kon er ook kritiek geventileerd worden op beleidskeuzes die werden gemaakt op basis van Florida's inzichten. Is alleen, of vooral, bouwen voor de creatieve klasse nodig, is het verstandig, en wat betekent het voor de rest van de stadsbevolking? Wil de creatieve klasse alleen maar in levendige buurten wonen en zo ja, vinden ze menging van bevolkingsgroepen,

\section{In het wetenschappelijk discours werd Florida zowel kop van Jut als icoon, met een door het plafond schietende citatiescore in academische tijdschriften tot gevolg}

etniciteiten en leefstijlen daadwerkelijk zo aantrekkelijk als Florida beweert? Kun je economische groei aanjagen door aantrekkelijke woon-werkmilieus te creëren? En is de creatieve klasse eigenlijk wel één klasse met één leefstijl? De lijst aan kritische vragen die gesteld werd is schier eindeloos. In het wetenschappelijk discours werd Florida zowel kop van Jut als icoon, met een door het plafond schietende citatiescore in academische tijdschriften tot gevolg (zie het artikel van Filip de Maesschalk elders deze AGORA). De academische hype was in ieder geval evident. Tien jaar na dato vragen we ons echter af of The Rise of the Creative Class en haar gelikte voorman wel zo'n grote invloed op sociaalruimtelijk beleid hebben gehad.

Zijn de stadsontwikkelingsstrategieën nu echt ingrijpend veranderd, of sloot dit verhaal goed aan bij trends in de stadsontwikkeling die al langere tijd gaande waren? We gingen in enkele Europese steden uit ons recente onderzoek op zoek naar de rol van creativiteit, kennis en innovatie in stadsregionale ontwikkelingsstrategieën.

\section{Zeven Europese steden}

Dublin is misschien wel het beste Europese voorbeeld van een stad die op de Florida-toer is gegaan. De lerse economie is één van de voornaamste slachtoffers van de kredietcrisis. Zowel de vastgoed- als de financiële sector gingen hard onderuit in lerland, en nog het meest in hoofdstad Dublin. Terwijl op nationaal niveau sindsdien vooral ingezet wordt op een 'slimme economie' en innovatie, waarbij verrassend genoeg toch weer veel wordt verwacht van innovaties in de financiële sector, staat in Dublin de laatste jaren creativiteit meer dan ooit centraal. Het label 'creatieve stad' zou Dublin een aantrekkelijker profiel moeten geven in de internationale concurrentiestrijd tussen steden en regio's. Daar kwam Dublin helaas wel erg laat mee, want intussen zijn er al zo veel creatieve steden uitgeroepen dat je daarmee niet erg meer opvalt. Van Florida's gedachtegoed is vooral zijn focus op aantrekkelijke woon- en werkmilieus overgenomen. Dublin investeert fors in 'place-making' voor de creatieve klasse. In het stadscentrum zijn en worden nieuwe stadsbuurten ontwikkeld met typische Florida-trekjes als hoge dichtheid, functiemenging en het stimuleren van levendigheid. Maar ook in andere beleidsvelden duikt creativiteit steeds vaker op als toverwoord voor economisch herstel zou moeten leiden.

Wat enthousiasme voor de creatieve klasse betreft komt Amsterdam aardig in de buurt van Dublin, hoewel Florida's werk daar net na 
verschijnen toch wat kritischer en met meer aarzeling werd ontvangen. Een deel van de verklaring kan zijn dat Amsterdam al aan veel van Florida's succescriteria voldeed voordat hij doorbrak, wat zijn werk hier misschien minder vernieuwend maakte. Elementen van de Amsterdamse ontwikkelingsstrategie die goed in Florida's straatje passen zijn bijvoorbeeld de 'uitrol' van de binnenstad naar negentiende- en vroeg-twintigste eeuwse buurten, de ontwikkeling van hoogstedelijke woon-werkmilieus langs het IJ (waaronder de recente omstreden plannen voor de transformatie van het Westelijk Havengebied) en het strategisch inzetten van het broedplaatsenbeleid als aanjager van stedelijke vernieuwing. Andere elementen van Amsterdam's strategie zijn eerder geïnspireerd door Europese concurrenten: de Amsterdamse Innovatiemotor (AIM, geïnspireerd door bijvoorbeeld Helsinki), de Economic Development Board, festivals als PICNIC en Fashion Week en het faciliteren en stimuleren van clustering en zakelijke netwerken. Hierbij wordt meer ingezet op het aantrekken en faciliteren van bedrijven, het aanmoedigen van innovatie van het al aanwezige bedrijfsleven en het vasthouden van al aanwezig talent dan op het aantrekken van talent. Omgekeerd is het Amsterdamse broedplaatsenbeleid een inspiratiebron voor veel andere Europese steden geweest.

De Britse steden in ons onderzoek, Birmingham en Manchester, zijn waarschijnlijk niet of nauwelijks door Florida's werk beïnvloed. De Britten hadden immers al in de jaren negentig het economisch potentieel van creativiteit ontdekt. Zij hadden namelijk hun eigen 'goeroes': consultants als Charles Landry en zijn bureau Comedia, maar ook Charles Leadbeater (een creativiteitsgoeroe), vroege onderzoekers van de creatieve industrie als Justin O'Connor, en Peter Hall met zijn 'Cities in Civilization'. Manchester ontdekte het economisch potentieel van de creatieve industrie eerder dan Birmingham. Waar Manchester begin jaren tachtig noodgedwongen radicaal afscheid nam van zijn verleden als industriestad, slaagde Birmingham er nog tot in de jaren tachtig in zijn industrie te moderniseren. Manchester heeft zich vanaf de jaren tachtig ontwikkeld als winkelstad, dienstenstad, creatieve stad en kennisstad. Birmingham begon pas in de jaren negentig aan die omslag en lijkt nog steeds een stap achter te lopen op Manchester. Een van de manieren waarop Birmingham de inhaalslag probeert te maken is door de culture en etnische diversiteit als een van de sterke punten in te zetten.

Barcelona is de afgelopen decennia erg sterk gebleken in citymarketing en imago-opbouw. De stad scoort goed op 'quality of life', het historische centrum en de negentiende eeuwse uitbreidingswijken hebben een hoge dichtheid en functiemenging, en er is een cultuuraanbod van hoog niveau. Ook de openbare ruimte is van hoge kwaliteit, mede doordat dit een belangrijke plaats inneemt in het stadsvernieuwingsbeleid. Andere speerpunten in Barcelona's ontwikkelingsstrategie zijn al jaren cultuur en innovatie. Al met al is veel van wat Barcelona sinds de jaren tachtig gedaan heeft in lijn met de beleidsadviezen van Florida, maar daar was het al lang voor de 'creatieve hype' uitbrak mee begonnen. Barcelona gold lang als een van de favoriete voorbeelden van strategisch beleid voor veel Europese steden.
Van de steden die we onderzocht hebben zijn de Duitse steden München en Leipzig waarschijnlijk het minst beïnvloed door de Florida's ideeën. München is een typisch voorbeeld van een stad die al decennialang min of meer dezelfde ontwikkelingsstrategie volgt, en daar veel succes mee boekt. Creativiteit is in München onderschikt aan technologische innovatie. De regio is niet alleen een vooraanstaand centrum van hoogtechnologische industrie, onderzoek en diensten, maar deze innovaties worden ook vaak succesvol in de markt gezet. Creatieve industrie is er wel, maar is vrij eenzijdig op media en ICT gericht. Er is een rijk cultuuraanbod, maar vooral op kapitaalkrachtig en ouder publiek gericht. Voor subcultuur of culturele broedplaatsen is in München weinig aandacht en weinig betaalbare ruimte. Op dit gebied doet Leipzig het een stuk beter. $\mathrm{Na}$ een langdurige demografische en economische krimp die al

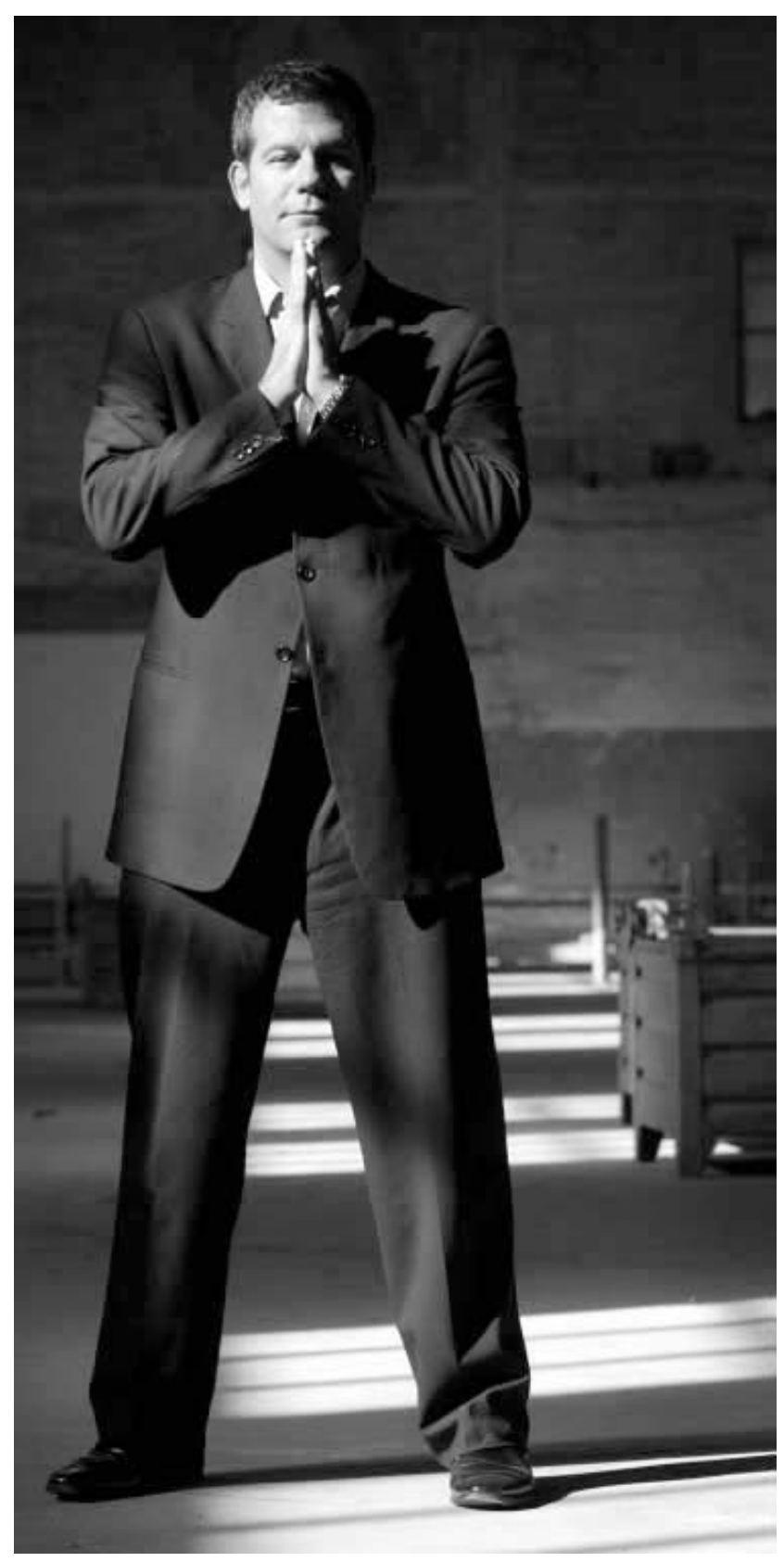

Richard Florida tijdens zijn bezoek aan Amsterdam in 2003 
onder het socialistische regime (1949-1989) inzette en na de Duitse hereniging in een stroomversnelling kwam, kwamen veel fabriekscomplexen en woonblokken vrij voor kunstenaars en startende creatieve bedrijfjes. Wat bij zowel Leipzig als München opvalt is het grote belang dat door ondernemers en werkers in de creatieve kenniseconomie gehecht wordt aan 'harde' vestigingsfactoren als bereikbaarheid, kosten, belastingen en geschikte woon- en werkruimten. Ook hebben beide steden een clusterstrategie als basis van hun economische beleid: meer Michael Porter dan Richard Florida. In München is dit echter een stuk makkelijker dan in Leipzig: München benoemt simpelweg de clusters die het er al decennialang goed doen, terwijl de clusterstrategie in Leipzig toch meer berust op 'wishful thinking'.

\section{Creatieve kookboeken}

Als er een algemeen 'recept' voor stedelijke ontwikkeling in Europa zou bestaan zou het er ongeveer zo uit kunnen zien: 'steden zijn steeds meer internationale concurrenten van elkaar. Ze concurreren om investeerders, bedrijven, bezoekers en talent. Omdat de industriële productie en eenvoudige dienstverlening naar lagelonenlanden is verdwenen, moeten Europese steden zich onderscheiden als centra van hoogwaardige dienstverlening, kennis, cultuur en creativiteit.' Variaties op dit thema zijn in vrijwel elke stedelijke of stadsregionale ontwikkelingsstrategie terug te vinden.

De middelen die hierbij ingezet worden vertonen ook de nodige overeenkomsten. Clustervorming of -stimulering, science parks en campussen, evenementen, 'landmark'-architectuur, nieuwe of vernieuwde musea en andere cultuurtempels, stads- en regiomarketing, oprichten of faciliteren van zakelijke en sociale netwerken, stimuleren van ondernemerschap en faciliteren van start-ups horen intussen tot de standaard ingrediënten van een stedelijke ontwikkelingsstrategie. Wat Richard Florida en zijn concepten 'creatieve klasse' en 'creatieve stad' nu precies aan dit beleidsrepertoire veranderd of bijgedragen hebben is moeilijk te bepalen. Zeker is dat Florida en de nodige andere 'goeroes' met open armen zijn ontvangen in vele Europese steden om inspiratie en advies voor stedelijke ontwikkeling te bieden.

Al met al vinden we in alle besproken Europese steden wel sporen van Florida-achtige ontwikkelingsstrategieën. Hoewel er ook de nodige parallellen in strategieën en middelen zijn zoals eerder aangegeven, zijn de onderlinge verschillen toch groter dan de overeenkomsten.

\section{Waarom}

De logische vervolgvraag is hoe het toch komt dat er in het academisch debat zo hevig gefulmineerd werd tegen de 'creatieve hype' onder beleidsmakers. Anders gesteld: hoe kan de hype over de hype verklaard worden? Het beantwoorden van deze vraag vereist een aparte studie, maar ter afsluiting vier mogelijke antwoorden. Ten eerste zette Florida de geografie weer stevig op de kaart. Met de opkomst van de creatieve klasse werd de invloed van plaats weer cruciaal. De kritiek op de 'creatieve hype' vond voor een belangrijk deel plaats op een ruimtelijk speelveld. Criticasters konden tegelij- kertijd kritiek leveren én de relevantie van hun discipline aantonen. Ten tweede is het werk van Florida multidisciplinair; de ene keer was hij socioloog, dan weer geograaf, en dan weer econoom. Dit had tot gevolg dat er vanuit diverse disciplines kritiek werd geuit. Ten derde leidde de enthousiaste ontvangst van Florida's gedachtegoed door nationale en Europese beleidsmakers er onvermijdelijk toe dat onderzoek naar creatieve industrie en creatieve klasse bovenaan de prioriteitenlijstjes voor onderzoekssubsidies verschenen. Hadden onderzoekers ook zoveel aandacht aan Florida besteed als er niet zo veel onderzoeksgeld binnen te halen was geweest? Tot slot is er de eenvoudige constatering dat succes kritiek uitlokt: Hoge bomen vangen veel wind. Succes in termen van verkoopcijfers of publicaties is op zichzelf echter geen reden tot kritiek, de veronderstelde gevolgen wel. In dit artikel hebben we beargumenteerd dat het met deze beleidsgevolgen wel meevalt. Nadat het Europese onderzoeksproject ACRE eerder al aantoonde dat de creatieve klasse theorie in Europa slechts beperkt houdbaar is, twijfelen we ook of commotie rondom creatief beleid gerechtvaardigd was. Was dit niet gewoon een hype over een hype en hadden onderzoekers zich niet met meer prangende zaken bezig kunnen houden?

\section{Marco Bontje (m.a.bontje@uva.nl) is universitair docent aan de afdeling Geografie, Planologie en Internationale Ontwikkelings- studies van de Universiteit van Amsterdam en redactieadviseur van AGORA. Peter Pelzer (p.pelzer@uu.nl) is promovendus aan de afdeling Sociale Geografie en Planologie van de Universiteit Utrecht en hoofdredacteur van AGORA. Beiden zijn betrokken geweest bij diverse onderzoeksprojecten naar creatieve steden, waaronder ACRE en Inventive City-Regions.}

Literatuurselectie

Bontje, M. \& Lawton, P. (2011) Competing for talent, firms and capital: city-regional competitiveness strategies in Amsterdam and Dublin. Paper gepresenteerd op Urban Affairs Association Conference, New Orleans, 16-19 maart 2011

Bontje, M., Musterd, S. \& Pelzer, P. (2011) Inventive city-regions. Path dependence and creative knowledge strategies. Farnham / Burlington, VT: Ashgate.

Franke, S. \& Verhagen, E. (red., 2005) Creativiteit en de stad. Hoe de creatieve economie de stad verandert. Rotterdam: NAi Uitgevers. Glaeser, E.L. (2004) 'Review of Richard Florida's 'The rise of the creative class'. [Online]. Beschikbaar via: http://economics.harvard. edu/faculty/glaeser/files/Review_Florida.pdf

Hall, P. (1999) Cities in Civilization; Culture, Innovation and Urban Order, London: Phoenix.

Landry, C. (2006) The art of city-making. London / Sterling, VA: Earthscan

Musterd, S. \& A. Murie (2010) Making Competitive Cities. Chichester: Wiley-Blackwell.

Peck, J. (2005) Struggling with the creative class, International Journal of Urban and Regional Research 29, 4: 740-770.

Storper, M. \& Scott, A.J. (2009) Rethinking human capital, creativity and urban growth, Journal of Economic Geography 9, 2: 147-167. 


\section{Het ruimtelijk concept als koker}

AUTEUR \& FOTOGRAFIE Wil Zonneveld

Echte hypes zijn bekend bij het brede publiek. Zover heeft een planologische hype het nooit gebracht. Toch zijn er planologische hypes waarvan de opkomst en verspreiding sterk lijkt op die van publiekshypes, om vervolgens deel te worden van het reguliere planologische werk. Dan is het opletten geblazen. Hypes werken immers als een koker: hoe langer de koker die voor het oog wordt gehouden, des te minder men ziet.

Planologische hypes zijn er in verschillende soorten. Zo zijn er hypes die betrekking hebben op de sturingskant van de ruimtelijke ordening. Het motto 'decentraal wat kan, centraal wat moet' werd bijvoorbeeld gretig aangegrepen door provincies en gemeenten om zoveel mogelijk taken en bevoegdheden overgeheveld te krijgen van het nationale ministerie. Dit terwijl het track record op deze bestuursniveaus, uitzonderingen daargelaten, nu niet direct oogverblindend glanst.

Deze bijdrage is gericht op een specifiek onderdeel van de planologische praktijk: het ruimtelijk concept. Kortweg zijn ruimtelijke concepten streefbeelden van de gewenste structuur of ruimtelijke inrichting van een gebied of plaats. Concepten zijn er in een bonte verscheidenheid. Er zijn concepten die betrekking hebben op morfologie, vooral op het verstedelijkingspatroon. Morfologische concepten refereren direct aan de visuele beleving van de ruimte, met name in termen van open en gesloten en alles wat daar tussenin zit. Voorbeelden zijn 'het Groene Hart', 'de Amstelscheg' of het recentelijk opgepoetste 'Hof van Delfland'. Deze klassieke, op groen-rood-blauw denken gebaseerde concepten kennen geen zware theoretische basis in de vorm van veronderstellingen over hoe huishoudens en bedrijven tot ruimtelijke beslissingen komen. Hoewel morfologische concepten eigenlijk de enige planologische concepten zijn die bekendheid bij het bredere publiek genieten - ze zijn bijvoorbeeld terug te vinden op de bruine toeristische borden langs de (snel)weg - zijn het geen echte planologische hypes. Daarvoor zijn dit soort concepten al te lang onder ons, eigenlijk al vanaf de voorzichtige opkomst van bovenlokale planning en stedenbouw in de jaren tien en twintig van de vorige eeuw. Dat een algemeen concept als 'open ruimte' vandaag de dag wordt gekoppeld aan plaats vormt een poging om planologische concepten te verankeren in de

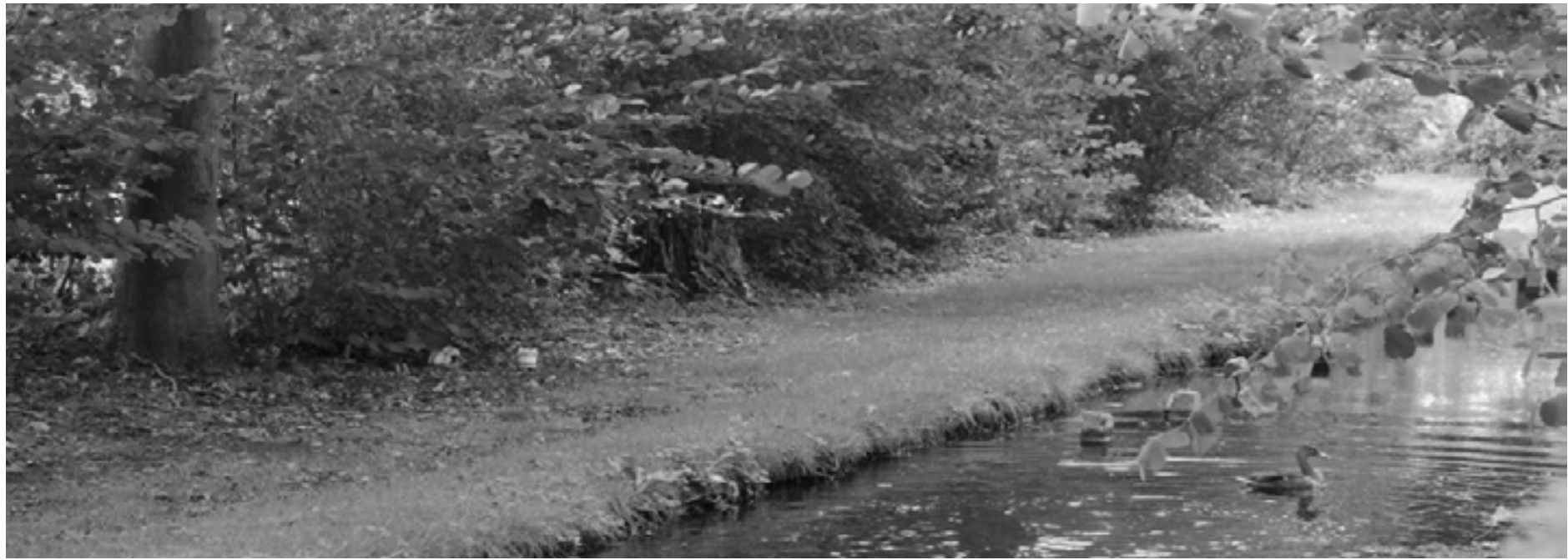

Een dergelijke groenstrook langs een sportterrein kon zomaar een ecologische verbindingszone worden 
beleving van het brede publiek, overigens geen onsuccesvolle branding De échte conceptuele hypes treffen we aan in de categorie van de functionele concepten. Dit zijn concepten die in hoge mate zijn gebaseerd op veronderstellingen over de drijvende maatschappelijke krachten achter ruimtelijke structuren. Recentelijke hypes betreffen vooral netwerkconcepten. In de praktijk verliezen ze echter al snel hun netwerkkarakter zodra ze door beleidssectoren worden aangegrepen om een eigen domein te claimen. Een drietal voorbeelden:

\section{Ecologische netwerken}

Het concept van de ecologische infrastructuur deed zijn intrede in het midden van de jaren tachtig van de vorige eeuw. Het is afkomstig uit de ecologie, het wetenschappelijk onderzoek dus. Kortweg komt het erop neer dat gebieden met ecologische waarden een zekere omvang moeten hebben, omgeven moeten zijn met gebieden die de negatieve invloed van menselijke activiteiten kunnen bufferen en verbonden zijn met andere ecologisch waardevolle gebieden om soortenuitwisseling mogelijk te maken.

\section{De makers van de nota 'ontdekten' dat steden deel uitmaken van grotere ruimtelijke systemen}

Het concept werd razendsnel opgepakt in de planologische praktijk; het werd een hype. Vanaf 1985 was er binnen een aantal jaren geen plan op gemeentelijk, provinciaal of nationaal niveau te vinden waarin het niet figureerde. Het concept schoof niet alleen een wetenschappelijke basis onder natuurbeleid, maar leek ook een belofte in te houden voor natuurbehoud in Nederland. Door versnippering, vervuiling, vermesting en verdroging leek er voor levensvatbare natuur in Nederland geen plaats meer te zijn. Het vergroten, maar vooral verbinden van natuurgebieden leek het ei van Columbus te vormen. Maar de slinger schoot door. Ik heb zelf in de praktijk van een stedenbouwkundig adviesbureau mogen meemaken dat elk strookje groen op een topografische kaart van 1:25.000 - een geliefde ondergrond voor ruimtelijk ontwerpen - opeens deel kon gaan uitmaken van een heus ecologisch netwerk, tot en met het overgeschoten stukje groen naast een sportcomplex van één à twee meter. Zie hier de (potentiële) kokerwerking van een planologische hype, waarmee niets ten nadele is gezegd van het concept van ecologische infrastructuur an sich. Met de Habitatrichtlijn van 1992 is het concept ook doorgedrongen in het Europese milieubeleid. De hype heeft er niet alleen voor gezorgd dat natuur serieus moet worden genomen in ruimtelijke planvorming. Het heeft ook bijgedragen aan een verdere juridificering - althans in Nederland - en technologisering (meten en rekenen) van de ruimtelijke planning. Doordat een concept als ecologische infrastructuur een frame biedt om tot afgewogen ruimtelijke keuzes te komen, kan van een verbreding van de besluitvormingspraktijk worden gesproken. Tegelijkertijd treden processen van versmalling op, zowel letterlijk (het groenstrookje) als procesmatig: kan inderdaad met zekerheid worden aangetoond dat een project geen negatieve invloed heeft op de natuurwaarden van een aangewezen gebied, zoals de afdeling bestuursrechtspraak van de Raad van State lijkt te denken?

\section{Stedelijke netwerken}

Jarenlang vasthouden aan het concept van de compacte stad heeft er op een gegeven moment, ruwweg eerste helft jaren negentig, toe geleid dat men de grenzen van de stedelijke agglomeratie is gaan zien als de ideale ruimtelijke horizon van het daily urban system. Met Peter Paul Witsen heb ik dit ooit eens aangeduid als de 'stad als bolletje': de wijze waarop op atlaskaarten van een kleine schaal vanouds steden en stedelijke regio's worden aangeduid. Mede op aandringen van de politiek en de Wetenschappelijke Raad voor het Regeringsbeleid is eind jaren negentig werk gemaakt van een vijfde nationale nota ruimtelijke ordening. Deze is door politieke turbulentie nooit in wetgeving omgezet, maar leeft als conceptuele bron nog altijd voort. De makers van deze nota 'ontdekten' dat steden niet op zichzelf staande grootheden zijn, maar deel uitmaken van grotere ruimtelijke systemen. Aanvankelijk werd gespeeld met twee concepten: netwerksteden (bijvoorbeeld Amsterdam in zijn wijdere omgeving) en stedelijke netwerken (bijvoorbeeld de Randstad). Later, in de uiteindelijke Vijfde Nota, werd de voorkeur gegeven aan één concept: het stedelijk netwerk.

Sterk vergelijkbaar met ecologische infrastructuur werd het concept gretig opgepakt in den lande: een hype dus. De metafoor van het 'netwerk' in relatie tot de stad werd zeer verschillend geïnterpreteerd. Gedurende de eerste jaren van deze eeuw waren er minstens vier interpretaties in omloop: de stad (bijvoorbeeld de Friese steden) als onderdeel van (grenzeloze) economische netwerken; het stedelijk netwerk als een nieuw niveau in de kernenhiërarchie; het stedelijk netwerk als de overtreffende trap van het stadsgewest; het stedelijk netwerk als grootschalige conurbatie.

Rijksplanologen hadden het stedelijk netwerk in de Vijfde Nota op een vrij klassieke wijze uitgewerkt. Het werd kennelijk nodig gevonden om 65(!) plaatsen toe te delen aan 13 stedelijke netwerken, keurig onderverdeeld in drie verschillende categorieën qua economisch gewicht. Van origine was

OVERUSSEL IN OROTER VEREAND

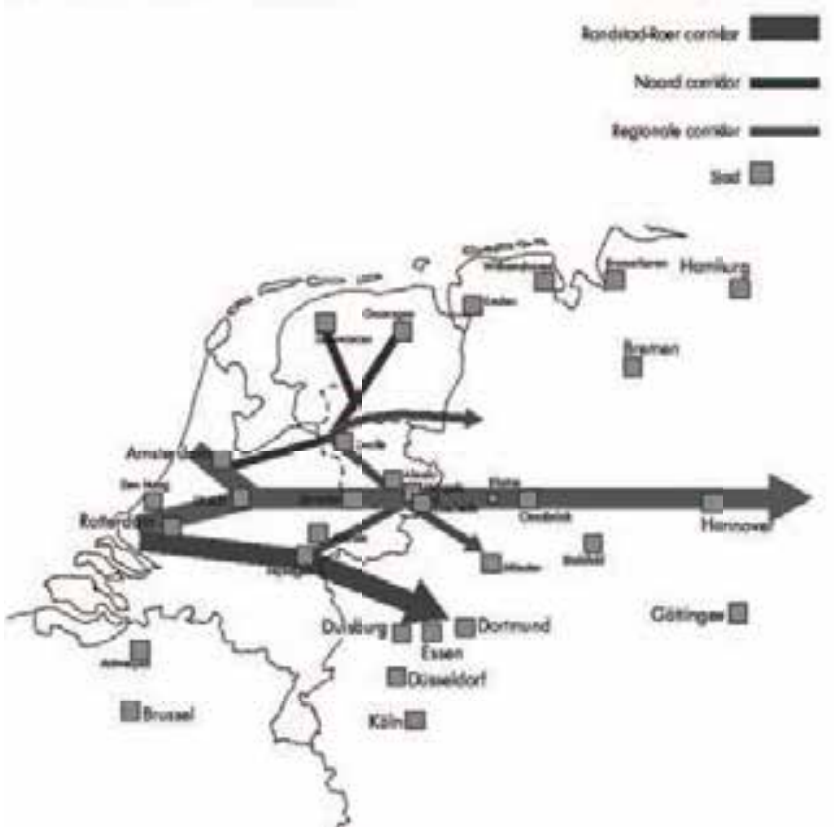

De West-Oost Corridor (uit: Streek Overijssel 2000+, 2000) 
het stedelijk netwerk/ de netwerkstad geënt op de relationele geografie, met 'The Network Society' van Manuel Castells als richtinggevend baken. Meer nog dan de 'Rise of the Creative Class' van Richard Florida enige jaren later, is de 'Network Society' een boek dat uitgroeide tot een ware hype in de wereld van het ruimtelijk beleid. In zijn vertaling naar de ruimtelijke ordening heeft de netwerkmetafoor echter de gebruikelijke metamorfose ondergaan: ruimtelijk afgebakend en ingesnoerd. Inmiddels heeft het stedelijk netwerk de achterdeur van de nationale ruimtelijke ordening verlaten. Het concept is officieel vervallen verklaard: ze zijn niet af te bakenen en het zijn de decentrale overheden die het concept maar moeten invullen en hanteren. Oorspronkelijk was het de bedoeling om samen met de betrokken regio's de stedelijke netwerken te gaan uitwerken min of meer langs eenzelfde spoor als dat heeft geleid tot de structuurvisie Randstad 2040, dat inmiddels ook vervallen is verklaard. Uiteindelijk werd geconcludeerd dat dit beter niet gedaan kon worden omdat anders parallel twee trajecten zouden zijn gaan lopen met deelname van grotendeels dezelfde personen en instellingen: én een uitwerking van stedelijke netwerken én de opstelling van de zogeheten gebiedsagenda's van het Meerjarenprogramma Infrastructuur, Ruimte en Transport (MIRT). Ziehier in een notendop de levensloop van het stedelijk netwerk: begonnen als een snel populair wordend fuzzy concept om greep te krijgen op veranderende stedelijke structuren, werd het vervolgens scherp afgebakend als zoekruimte voor nieuwe bouwlocaties en om eventueel te kunnen dienen als verdeelmechanisme voor geldstromen (zie bijvoorbeeld IPO Nieuws, 1 juni 2007), om uiteindelijk als beleidsconcept door de huidige minister als vervallen verklaard te worden. Dit is een trieste beleidscyclus. Steden zijn geen lokaal verschijnsel. Stedelijke structuren doorsnijden bestuurlijke indelingen terwijl economische activiteiten ingebed zijn in relaties die zich over reeksen van ruimtelijke schaalniveaus uitstrekken. Wat de implicaties hiervan zijn voor ruimtelijke ordening op regionaal niveau is echter nog niet erg veel duidelijker geworden sinds veertien jaar geleden het netwerkconcept zijn intrede deed.

\section{Economische netwerken}

Bijna gelijk oplopend met de opkomst van stedelijke netwerken, en deels daarmee concurrerend, kwam een denken op in termen van ruimtelijkeconomische netwerken. Aanleiding was het project Europa 1992 wegvallende binnengrenzen binnen de Europese Gemeenschap - en het uiteenvallen van het voormalige Oostblok. De nieuwe Europese politieke en ruimtelijke configuratie kreeg invloed op de inhoud van ruimtelijke plannen in Nederland. Binnen de context van een monidaliserende economie en de nieuwe betekenis die landsgrenzen kregen, ontwikkelde zich een nieuwe stroming. Deze kan worden aangeduid als positionering: wat is de positie van een stad of een regio (of een heel land) in wijder verband? Positionering leidde ertoe dat nieuwe ruimtelijke concepten over Nederland en Europa werden uitgerold. Dit leidde bijvoorbeeld tot claims dat de ontwikkeling van Hengelo en Enschede wel degelijk te maken heeft met Berlijn en dat Zwolle en Groningen relaties hebben met Scandinavië. Vooral het corridorconcept was debet aan dit denken.

De corridor is een lineair concept dat, om het plastisch te zeggen, vrijwel eindeloos kan worden uitgerekt. In een Europese studie van de Rijksplanologische Dienst uit begin jaren negentig is uiteengezet dat een corridor gezien kan worden als een keten van deelgebieden, van 'schakels'. Binnen de schakels en tussen in elkaars nabijheid gelegen schakels kan sprake zijn van intensieve relaties, zonder dat dergelijke relaties zich over de volle lengte van een corridor uitstrekken of hoeven uit te strekken. Wordt de corridor daarentegen als een soort van functionele eenheid opgevat, dan hebben alle plekken binnen zo'n corridor een relatie met elkaar De verwachting is dat die relaties vooral tot uitdrukking komen in fysieke stromen. In dit denken hebben Berlijn en Warschau een relatie met Twente en Zwolle met Helsinki. We zien dat eigenlijk hetzelfde gebeurt als wat met ecologische infrastructuur en het stedelijk netwerk heeft plaats gevonden. Een concept dat initieel is geënt op hypothese- en theorievorming over ruimtelijke relaties wordt morfologisch uitgewerkt. Een diffuse structuur wordt afgebakend en is daarmee op kaarten te tekenen, meestal in de vorm van (dikke) pijlen.

Rond de eeuwwisseling was sprake van een heuse corridor hype. De zogeheten Noordelijke Corridor veronderstelde steeds sterker wordende relaties tussen Noord-Nederland, Noord-Duitsland en de Noordse landen, relaties die volgens de noordelijke provinciebesturen gefaciliteerd zouden moeten worden met een hogesnelheidslijn. Ook de Randstad zou hierdoor veel beter in Europa gepositioneerd worden. De Zuiderzeelijn is echter gesneuveld en de Noordcorridor werd geschiedenis.

De West-Oostas c.q. corridor is een vergelijkbaar concept. Oost-Nederland (Twentse steden) vormt een 'stepping stone' tussen de Randstad en Hannover-Berlijn-Warschau. Infrastructurele verbindingen moesten derhalve verbeterd worden. Ook dit concept is inmiddels vergeten, deels omdat het in het oosten van het land niet lukte om de rijen gesloten te houden: Gelderland was bij nader inzien van mening dat de relaties met Duitsland via Arnhem-Nijmegen toch belangrijker zijn dan die via de

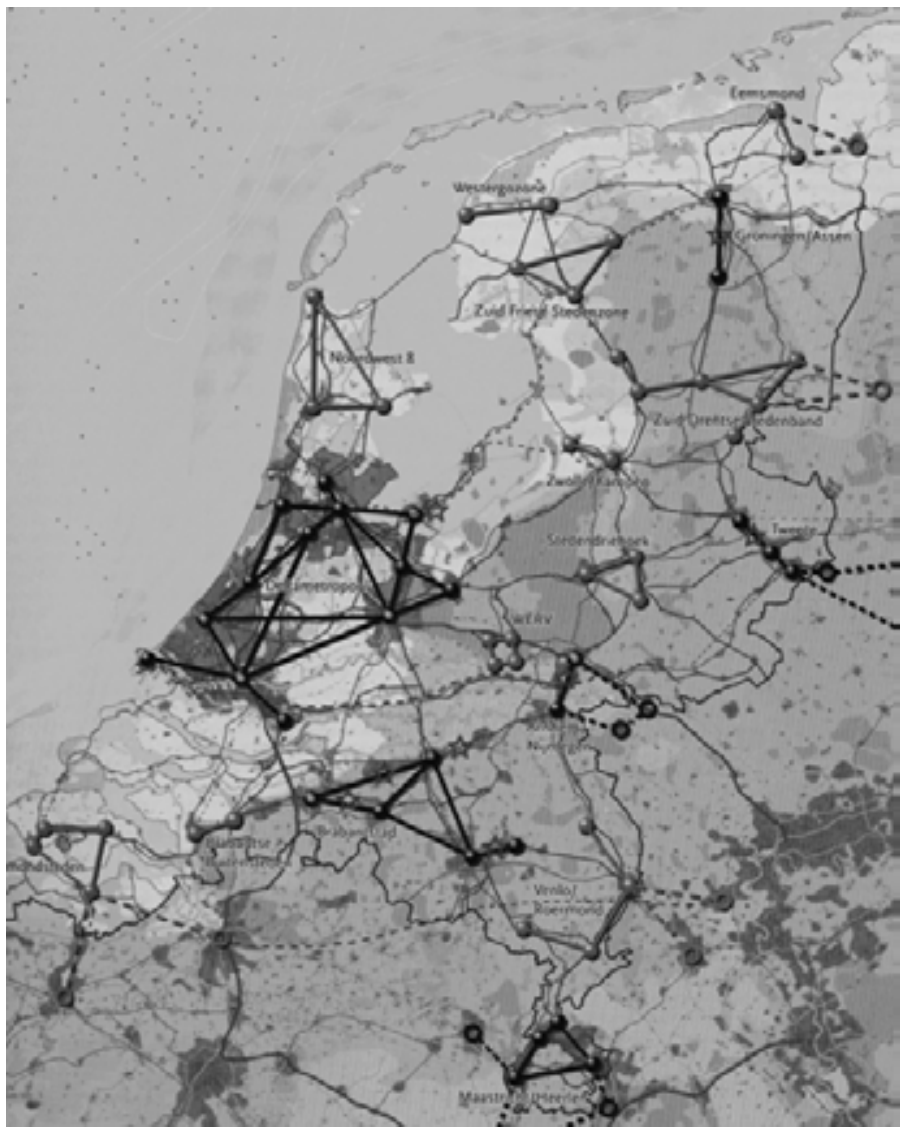

Stedelijke netwerken minutieus afgebakend (uit: Vijfde nota over de ruimtelijke ordening; Deel 3, 2002) 
Twentse Steden.

Brabant en Limburg als een Voorland van de Randstad, bezien vanuit een zuidelijke windrichting, is een vergelijkbaar positioneringsconcept. Weliswaar gaat het hier strikt gesproken niet om een corridor, maar het gaat wel degelijk eveneens voor een belangrijk deel om een infrastructuurdiscours. De positionering van het Voorland in Noordwest-Europees verband zou volgens de betrokken stedelijke en provinciale bestuurders versterkt kunnen worden via een verbetering van de interne en externe bereikbaarheid. Vooral een verbetering van de interne spoorverbindingen stond hoog op de wensenlijst.

\section{Concepten kunnen populair worden doordat zij fungeren als een onderbouwing van een claim voor beleidsaandacht, investeringen en subsidies}

Het Voorlandconcept is inmiddels ook aan de vergetelheid prijs gegeven. Dat geldt overigens niet voor een ander concept dat deel uitmaakte van het Voorland denken: de kennis- en dienstverleningsas Amsterdam-Maastricht. In de Nota Ruimte is dit concept overgenomen als de 'A 2 Kennisas'. Het Ruimtelijk Planbureau maakte overigens gehakt van dit concept door te stellen dat de ruimtelijke structuur van kennis in Nederland te ingewikkeld in elkaar zit om tot een bepaalde as of regio teruggebracht te worden. De opstellers van de Nota Ruimte trokken zicht echter niets hiervan aan. Het denken in termen van economische assen en kennisassen is hardnekkig. Zo zou er een kennisas van Delft naar Rotterdam lopen en wordt Amsterdam-Eindhoven gezien als economisch kerngebied. En Nederland ligt bezaaid met brainports: de vandaag de dag meest voorkomende nodale variant van de kennisas.

\section{Conclusie}

Elk ruimtelijk concept dat wordt geïnitieerd en aanslaat is in zekere zin een hype. De bedenkers en makers van een concept (die overigens vaak moeilijk aan te wijzen zijn omdat concepten een kind van hun tijd vormen en derhalve nogal eens verschillende protagonisten hebben) hopen dat hun concept wordt overgenomen en vertaald in operationele beslissingen: aanwijzing van gebieden, toekenning van subsidies, aanleg van infrastructuur etcetera. Processen van manipulatie, machtsstrijd, verdrukking van alternatieve concepten en discoursen: het is eigen aan conceptualisering van ruimte. Concepten kunnen een hype worden omdat zij een soort van nieuw kennisfundament aandragen. Dit was zeker het geval bij de ecologische infrastructuur en het stedelijk netwerk. Ook kunnen concepten populair worden doordat zij fungeren als een onderbouwing van een claim voor beleidsaandacht en investeringen en subsidies. Branding van een regio of stad naar de buitenwereld of de hand ophouden bij de nationale overheid of de Europese Unie (corridor-concepten zijn zeer populair in INTERREG: het EU programma bedoeld voor grensoverschrijdende en transnationale samenwerking) zijn dan belangrijke functies van een gehyped concept. De hier behandelde concepten hebben één kenmerk gemeenschappelijk: het zijn allemaal concepten die geënt zijn op netwerkdenken, daar hun kennisbasis vinden, maar vanwege een bepaalde doelrationaliteit, versmald en verengd worden. Diffuse ruimtelijke structuren worden afgebakende ruimtes. Er vindt, met andere woorden, verenging plaats. Een ruimtelijk concept wordt een koker: alleen wat door het gaatje zichtbaar is, is werkelijkheid. Dit gevaar is eigen aan het gebruik van ruimtelijke concepten, maar wordt sterker als een concept een hype wordt.

Wil Zonneveld is als hoogleraar Stedelijke en Regionale Ontwikkeling verbonden aan het Onderzoeksinstituut OTB en de Faculteit Bouwkunde van de Technische Universiteit Delft. In 1991 is hij gepromoveerd op een studie naar het gebruik van ruimtelijke concepten. Verschillende onderzoeken hebben sindsdien plaats gevonden, onder meer een project bij het toenmalige Ruimtelijk Planbureau.

Literatuurselectie

Duinen, L van (2004) Planning Imagery: The Emergence and Development of New Planning Concepts in Dutch National Spatial Policy, Amsterdam: Universiteit van Amsterdam (proefschrift; uitgave in eigen beheer).

Goedman, J., Zonneveld, W., Houtsma, W.H. (2011) (Red.) Ruimtelijke

Ontwikkeling in Drievoud, Den Haag: Sdu Uitgevers

Hagens, J.E. (2010) The performance of landscape concepts in spatial planning; Branding, bonding and bringing about, Wageningen: Wageningen UR (proefschrift; uitgave in eigen beheer).

Rijksplanologische Dienst (1991) Perspectieven in Europa; Een verkenning van opties voor een Europees ruimtelijk beleid, Den Haag: Ministerie van Volkshuisvesting, Ruimtelijke Ordening en Milieubeheer.

Parlementaire werkgroep Vijfde Nota ruimtelijke ordening (2000). Notie van ruimte. Op weg naar de Vijfde Nota ruimtelijke ordening. Tweede Kamer 27 210, nr. 1-2. Den Haag: Sdu Uitgevers.

Raspe, O. e.a. (2004) Kennis op de kaart; Ruimtelijke patronen in de kenniseconomie, Rotterdam/Den Haag: NAi Uitgevers/Ruimtelijk Planbureau Witsen, P.P., Zonneveld, W. (1996) 'Balkanisering in conceptenland?: Planconcepten voor stad en economie', Stedebouw \& Ruimtelijke Ordening 77, nr.2, pp. 25-32.

Wetenschappelijke Raad voor het Regeringsbeleid (1998) Ruimtelijke ontwikkelingspolitiek, Rapporten aan de Regering nr.53, Den Haag: Sdu Uitgevers.

Zonneveld, W. (1991) Conceptvorming in de ruimtelijke planning; Patronen en processen, Planologische Studies nr.9a, Amsterdam: Planologisch en Demografisch Instituut Universiteit van Amsterdam (proefschrift; download: http://dare.uva.nl/record/326056).

Zonneveld, W., Dubois, A., Gløersen, E., Stead, D. (2007) Polycentric Urban Development and Rural-Urban Partnership; - Thematic Study of INTERREG and ESPON activities, Esch-sur-Alzette/Viborg: ESPON Coordination Unit/ INTERACT Point Qualification and Transfer (http://www.espon.eu/export/ sites/default/Documents/Projects/ESPON2006Projects/ESPONINTERactStudies/PolycentricUrbanDevelopment/fr-INTERACT-Poly-Jan2007.pdf) Zonneveld, W., Verwest, F. (2005) Tussen droom en retoriek; De conceptualisering van ruimte in de Nederlandse planning, Den Haag/Rotterdam: Ruimtelijk Planbureau/NAi Uitgevers. 


\section{Lulkoek}

AUTEURS Ewald Engelen

FOTOGRAFIE Karsten van Loon \& redactie AGORA

Beleid en groeicoalities moeten altijd met een verhaal verantwoord worden aan de kiezer. Deze verhalen bestaan echter steeds vaker uit gebakken lucht en opgepomte hypes, ofwel uit lulkoek. Tegelijkertijd lijken pers en academia machteloos deze lulkoek door te prikken, met als gevolg dat private belangen vrij spel hebben.

Eind april ontving ik een uitnodiging van de Kenniskring Amsterdam om een bijeenkomst over de financieel-zakelijke dienstverlening in Amsterdam bij te wonen. Onder de zelfingenomen titel 'Global Challenges... Dutch Solutions' zouden advocaten, bankiers, en lobbyisten mij bijpraten over het belang van de financieel-zakelijke dienstverlening voor de Amsterdamse economie en de toekomstige groeimogelijkheden van deze sector. Was getekend: Eberhard van der Laan, de nieuwbakken burgemeester van Amsterdam.

De bijbehorende tekst was een wonder van ronkende rechtpraterij van wat tijdens de crisis krom was gebleken. Het begon er mee dat de financiële en de zakelijke dienstverlening doodleuk op een hoop werden geveegd. Zo kwamen er tenminste imposante cijfers uit, moeten de opstellers hebben gedacht: 90.000 ondernemingen, 295.000 werknemers, een kwart van het Amsterdamse BBP en groeicijfers van boven de vier procent. In werkelijkheid is de financieel-zakelijke dienstverlening natuurlijk helemaal geen 'sector', maar eerder een vergaarbak van postindustriële activiteiten waar statistici uit het industriële tijdperk geen raad mee weten. Wat dit moest verhullen was dat de financiële sector in Amsterdam al jaren aan het krimpen is. Vorig jaar werkten er vijftien procent minder mensen dan in 2001. In het vermogensbeheer zijn 4000 banen verdwenen, in de effectenhandel werken nog maar 2500 mensen en bij de banken zijn sinds 2008 bijna 3000 banen verdwenen. Stimuleren is dan trekken aan een dood paard.
Geen goed uitgangspunt voor een ambitieus economisch ontwikkelingsprogramma.

Tenenkrommend was de bijgevoegde agenda. Terwijl het Nederlandse pensioenstelsel in zijn voegen kraakte, presteerden de organisatoren het om een spreker van Holland Financial Center uit te nodigen die 'de kracht van ons pensioenstelsel en de exploitatiemogelijkheden ervan in het buitenland' uit de doeken moest doen. En terwijl advocatenkantoren als Loyens \& Loeff schatrijk

\section{Lulkoek is een uitnodiging aan de ontvanger om te geloven in de realiseerbaarheid van de stand van zaken die de propositie niet beschrijft of verklaart, maar suggereert en projecteert}

worden van het opzetten en beheren van trustmaatschappijen voor buitenlandse belastingontduikers, suggereerde de titel van de bijdrage van de bestuursvoorzitter - tevens gastheer - van Loyens \& Loeff dat de aantrekkelijkheid van het Nederlandse belastingparadijs meer te danken is aan de kwaliteit van de wetgeving dan aan de extreem lage belastingtarieven. Leg dat de inwoners van - zeg - Nigeria maar eens uit!

Erger dan de leugenachtigheid van wat er wel stond, was wat er werd verzwegen. Blijmoedig verwees de uitnodiging naar de Amsterdamse Economic Development Board (EDB) die het in zijn ondoorgrondelijke wijsheid had behaagd om de financieel-zakelijke dienstverlening tot één van de zeven speerpunten van de 
Metropoolregio uit te roepen. Tegelijkertijd zweeg de tekst over dat wat aan de wieg moet hebben gestaan van dit bancaire charmeoffensief: een financiële crisis die de Nederlandse belastingbetaler bijna 25 procent van het bbp heeft gekost. Daarmee is Nederland een van de zwaarst getroffen landen ter wereld. En dat heeft de belastingbetaler te danken aan slap toezicht, te lage kapitaalbuffers en goed voor zichzelf zorgende bankiers die voor de crisis op grote schaal wilden meedoen met de grote jongens in Wall Street en de Londense City. Met dank aan de groeifixatie van politici en toezichthouders. Maar daarover in de uitnodiging geen woord.

\section{Bestuurlijke epidemie van het Woord}

Hoe is het mogelijk dat drie jaar na dato de gemeente Amsterdam zich wederom voor het karretje van de bancaire sector laat spannen? Hoe kan het zijn dat juist sociaal-democraat Van der Laan tekent voor een uitnodiging die zo opzichtig om de hete brij van de crisis en de buitenproportionele omvang van de Nederlandse financiële sector heen draait? En waarom lenen de academici in de EDB - Louise Fresco, Henriette Maassen-Van den Brink, de beide bestuursvoorzitters van de Amsterdamse universiteiten - hun wetenschappelijke reputatie en die van hun instellingen voor het witwassen van dit soort onzin?

Deze casus staat niet op zichzelf. Wie er oog voor heeft, ziet de sporen van deze bestuurlijke epidemie overal. Of het nu gaat om de Noord-Zuidlijn, de Olympische Spelen 2028, krachtwijken, burgerschapscursussen, kenniseconomie, de creatieve klasse, toponderzoek, innovatiebeleid of de Zuidas - steeds zijn het discursieve beleidsassemblages die daadkracht suggereren, groei en succes simuleren, en daarmee draagvlak moeten genereren. Dat het, zoals met de Noord-Zuidlijn en, in mindere mate, de Zuidas, materieel is neergeslagen in miljarden verslindende ruimtelijke interventies, laat onverlet dat ook in deze gevallen in den beginne het Woord was. Goddank is het in het merendeel van de overige gevallen bij het Woord gebleven. De bestanddelen ervan zijn steeds dezelfde: een projectorganisatie met een eigen prominente 'trekker', een eigen adres, een eigen logo en eigen briefpapier, meestal gevolgd door een futurologische mijmeringen uitlokkende maquette of een glanzende brochure met fraaie futuristische vergezichten en een website die dat alles nog eens virtueel verdubbelt. Dit alles geflankeerd door een lange reeks van rapporten en evaluatiestudies onder leiding van gerenommeerde professoren werkzaam bij imposante instituten die de plannen, voornemens, interventies en projecten - al dan niet voorzien van het keurmerk van het NICIS - aan academische legitimiteit helpen.

Het succes van deze assemblages kan niet worden afgelezen aan de realisering van doelstellingen. Die zijn daarvoor te diffuus sociale cohesie, innovatie, groei, beter onderwijs, succesvolle steden: hoe meet je dat? - en vooral te multicausaal. Veel belangrijker is de mate waarin de quasi-causale fraseologie waaromheen deze assemblages zijn geconstrueerd - kennisvalorisatie in het geval van de kenniseconomie; actief burgerschap in

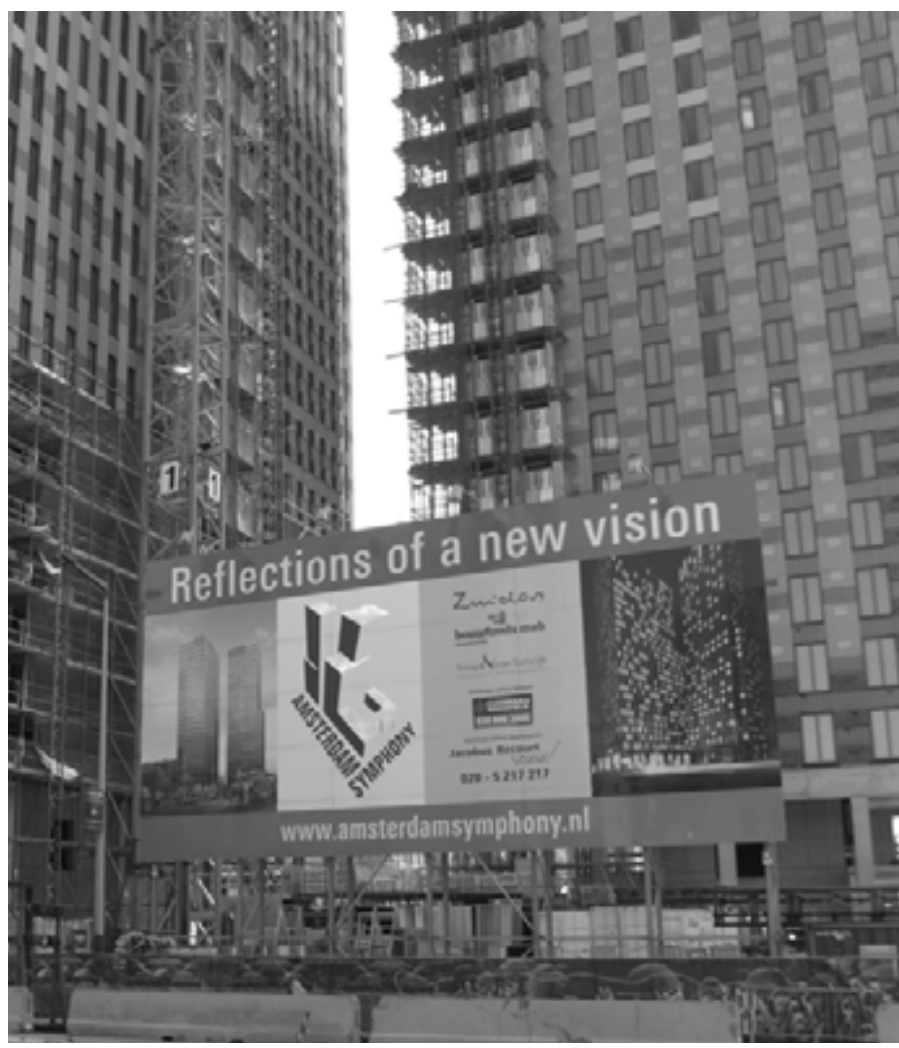

De Zuidas in aanbouw; een miljarden verslindende ruimtelijke interventie

het geval van sociale cohesie; r\&d investeringen in het geval van innovatie - terecht komt in die liturgische brij van beleidskundige platitudes die als pasmunt van de inwijding circuleert in de broze netwerken van de Nederlandse elite. En die - maar dit terzijde - gesprekken met leden van de elite tot zo'n buitenwereldlijke ervaring maakt: geloven deze sprekende pakken zelf in de liturgie die ze reciteren?

Voor de crisis waren het belang van innovatie, excellent onderwijs, de creatieve klasse, en meer sociale cohesie voor het welbevinden van Nederland boven iedere twijfel verheven. Dat de staat helemaal niet over innovatie gaat en dat niet elke innovatie (bijvoorbeeld financiële) altijd wenselijk is; dat onderwijs een positioneel goed is en meer onderwijs dus niet automatisch beter is; dat sociale cohesie niet hetzelfde is als gemengde wijken en zeker niet betekent dat we allemaal van elkaar moeten houden; en dat de creatieve klasse in Nederland vooral een subsidieverslaafde culturele sector bemenst die parasiteert op de staat en dus nooit de autonome stedelijke groeimotor kan zijn waar de voorstanders haar voor houden - dat soort piskijkerige kanttekeningen werden wel degelijk gemaakt maar drongen maar mondjesmaat tot de beleidselite door.

Dat heeft niets met fact free politics te maken, maar alles met de aard van deze discursieve beleidsassemblages. Feitenvrije politiek is namelijk een opgestoken middelvinger in de richting van de argumenterende klasse en als zodanig, net als de leugen, parasitair op het waarheidsspel dat inherent is aan argumenteren. Sterker nog, populisten gaan er prat op de argumenterende klasse te hebben ontmaskerd als een babbelende kaste die haar eigen particuliere wensen en belangen maskeert als beschavings- 
offensief. Maar ontmaskering, dat is toch bij uitstek een aan het waarheidsspel ontleende geste die de progressieve babyboomer sinds de jaren zestig tot kunstvorm heeft verheven? Geen wonder dat diezelfde babyboomer er zoveel moeite mee heeft om haar te pareren.

\section{Waarheid, haalbaarheid of lulkoek?}

De narratieven waar ik het over heb, zijn door de Amerikaanse taalfilosoof Harry Frankfurt kernachtig samengevat als 'bullshit'. In goed Nederlands: lulkoek. Kenmerkend voor lulkoek is dat het geen enkele waarheidsclaim doet en daardoor resistent is tegen feitelijke weerlegging. Dat verklaart waarom lulkoek zo weinig vatbaar is voor kritiek en niet kan worden ontmaskerd als leugen. Wie lulkoek te lijf gaat met empirische tegenwerpingen bezondigt zich stomweg aan een categoriefout. Lulkoek is namelijk voorbij waar of onwaar, goed of fout, juist of onjuist.

\section{De elite kan zijn greep op het staatsapparaat alleen maar vestigen door steeds nieuwe coalities te smeden die uiteindelijk zijn gebaseerd op lulkoek}

Lulkoek laat zich nog het beste beschrijven als een simulacrum van een propositie met beschrijvende of verklarende inhoud. Ter verduidelijking het meest bekende voorbeeld van zo'n simulacrum: de hostie en de wijn zijn niet het vlees en bloed van Jezus. Tegelijkertijd kunnen de hostie en de wijn alleen bij gratie van de gewijde context present stellen door juist niet te zijn wat ze suggereren, namelijk het bloed en vlees van Jezus. Net zo ziet lulkoek er weliswaar uit als een gewone zin, maar is het eigenlijk een uitnodiging aan de ontvanger om te geloven in de realiseerbaarheid van de stand van zaken die de propositie niet beschrijft of verklaart, maar suggereert en projecteert. Lulkoek is zo bezien een manmoedige poging om de ontvanger ervan te overtuigen dat met het doen van de uitspraak een 'feit' is geschapen dat net zo hard en definitief is als het 'institutionele feit' van wederzijdse juridische verplichtingen dat het uitspreken van het ja-woord bij een huwelijk in het leven roept.

$\mathrm{Er}$ is niemand bij de gemeente Amsterdam die serieus gelooft dat Amsterdam ooit tot de top zeven van Europese financiële centra zal gaan behoren, een 'Europese koploper in de diensteninnovatie' zal worden of 'een broedplaats voor toptalent in de financieel-zakelijke dienstverlening', zoals de doelstellingen van de EDB voor 2020 luiden. Daarvoor ontbreekt het Amsterdam ten enenmale aan omvang en massa, mist de gemeente geld, expertise en instrumenten, en is de stad teveel afhankelijk van toeval en ontwikkelingen elders. Krijgen wij onze vergrijzingskosten onder controle? Redt de euro het? Wat betekent de opkomst van China? Worden banken en financiële markten aan banden gelegd? Wat betekent dat voor Londen en Frankfurt?

Maar om waarheid, waarschijnlijkheid en haalbaarheid gaat het helemaal niet bij lulkoek. Belangrijker dan het realiteitsgehalte van de narratieven is hun mobiliserende kracht. Lulkoek bestaat uit beleidsverhalen die tegelijkertijd vier doelen dienen: ze suggereren daadkracht; ze projecteren een toekomst van gedeeld succes en brede welvarendheid; ze genereren draagvlak en creëren gemeenschap; en ze verhullen de altijd kwetsbare coalitie van particuliere belangen die zich rond deze narratieven hebben geplooid. De bouw-vastgoed-financiële coalitie in het geval van de Zuidas; de bouw-transport-infrastructuur coalitie in het geval van de Noord-Zuidlijn; de universitaire coalitie van NWO,KNAW en VSNU in het geval van de kenniseconomie; de corporatiewelzijnscoalitie in het geval van de sociale cohesie agenda. Postdemocratie en emancipatie Lulkoek gedijt in postdemocratische maatschappijen, zoals de Britse socioloog Colin Crouch samenlevingen als de onze heeft gedoopt. Door het afkalven van de naoorlogse achterban van georganiseerde belangenverbanden zoals vakbonden, werkgeversorganisaties, politieke partijen, kerken en sectorale organisaties is het politieke spel steeds meer veranderd van een elitair onderhandelingsspel achter gesloten deuren in een quasi-openbaar gezelschapsspel. Dat spel draait om het vertellen van overtuigende verhalen. In de relatief stabiele politieke, culturele en sociaaleconomische condities van de jaren vijftig, zestig en zeventig was het vertrouwen van burgers en ingezetenen in hun politieke en corporatistische vertegenwoordigers zo groot dat deze zonder last of ruggespraak in de beslotenheid van rokerige achterkamers hun ingewikkelde onderhandelingen konden voeren

Dat is verleden tijd. Zoals de sociale en juridische categorieën van staat, zuil, gezin en bedrijf steeds poreuzer zijn geworden, zo zijn ook de oude loyaliteiten die daarmee verbonden waren geleidelijk aan verdwenen. Elites kunnen niet langer rekenen op de vanzelfsprekende instemming van hun ondergeschikten, als ze überhaupt al weten wie dat zijn. Het gevolg is dat beleid meer en meer de uitkomst is geworden van een strijd tussen verschillende losse elitaire facties. Deze betwisten elkaar de mogelijkheid om de narratieven waarachter zij zich tijdelijk hebben geschaard te transformeren in relatief stabiele coalities. Die coalities geven vervolgens toegang tot bureaucratische informatiekanalen, agendabepalende media en intellectuelen en daarmee tot electorale steun en de (steeds geringere) materiële middelen van de staat en haar toeleveranciers.

Je kan dat betreuren, zoals Crouch doet, maar ook zien als volgende stap in een langdurig emancipatieproces. De relatie tussen burger aan de ene kant en staat en elite aan de andere is kennelijk zo symmetrisch geworden dat de elite zijn greep op het staatsapparaat alleen maar kan vestigen door steeds nieuwe coalities te smeden die uiteindelijk zijn gebaseerd op lulkoek. Nu onderdanen niet meer met het geweer gedwongen kunnen worden in te stemmen met elitaire plannen, en nu het gezag van 


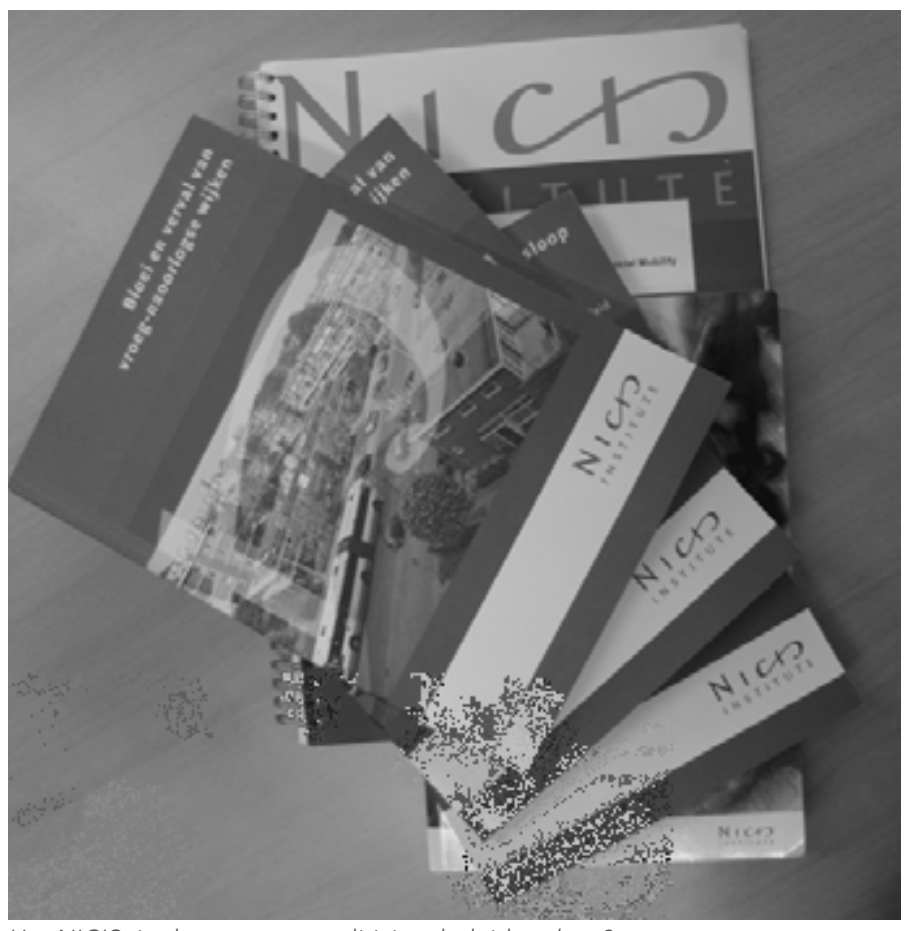

Het NICIS: in de greep van politici en beleidsmakers?

elites door het stijgende onderwijspeil van de bevolking en de onttovering van eliteposities steeds minder vanzelfsprekend is geworden, rest postdemocratische elites nog slechts de verleiding van veelbelovende narratieven. Deze gaan vervolgens in alle electorale openheid de strijd aan met de botsende narratieven van concurrerende coalities. Daarmee zou de postdemocratie van Crouch idealiter democratischer kunnen zijn dan de democratische hoogtij van de jaren vijftig, zestig en zeventig die hij nostalgisch betreurt. Helaas is in werkelijkheid de strijd tussen de narratieven nauwelijks gelijkwaardig en ontbreekt het aan onafhankelijke machtsbolwerken die gezaghebbend de doelstellingen van de verschillende narratieven op hun publieke pretenties kunnen toetsen. Welke groeicoalities gaan achter welke narratieven schuil? Hoe waar, waarachtig, haalbaar en waarschijnlijk zijn hun narratieven?

Intellectuele armoede

Van oudsher hadden twee maatschappelijke actoren die taak: de 'vrije' pers en Academia. Twee luizen in de pels van de elite. De eerste is door commercialisering, technologische innovatie en de democratisering van nieuwsgaring steeds slechter toegerust voor haar kritische taak. Kranten, tijdschriften en omroepen verkochten ooit hun maatschappijkritiek voor een schappelijke prijs aan hun leden en abonnees. Met het verscheiden van hun monopolie op informatieverwerving, duiding en verstrekking is hun bedrijfsmodel niet langer levensvatbaar en zijn media momenteel naarstig op zoek naar nieuwe functies en rollen. Het is lastig te voorspellen wat de uitkomst gaat worden.

Rest Academia. De eerlijkheid gebiedt mij te zeggen dat die zich de afgelopen jaren steeds ho(e)riger aan de heersende belangencoalities is gaan betonen. Haar eigen bestuurders die zich hebben afgewend van de academische werkvloer en zich in toenemende mate hebben ingelikt bij de bestuurlijke elite hebben hier in belangrijke mate aan bijgedragen. Net als de media onzeker over haar maatschappelijke positie, haar functie en haar financiering heeft de universiteit zich steeds meer onderworpen aan een utilitair discours dat haar status laat afhangen van een conformistische norm van kennisvalorisatie. Steeds minder geld is beschikbaar voor kritisch, onafhankelijk onderzoek. Steeds groter is de greep geworden van politici en beleidsmakers op de probleemdefinities die sociale wetenschappers vervolgens mogen onderzoeken. De onderzoeksprogramma's van 'topinstituut' NICIS zijn daar een uitmuntend voorbeeld van. Ambtenaren van grote en middelgrote gemeentes hebben een steeds grotere zeggenschap gekregen over welke onderzoeksvoorstellen subsidiabel zijn en welke niet. Steeds minder ruimte is er voor kritisch onderzoek dat de heersende onderzoeksagenda's en de dominante probleemdefinities zelf aan kritiek wil onderwerpen.

Dat is geen verrassing. Om lulkoek te transformeren in een institutioneel feit en de strijd der narratieven (tijdelijk) in hun voordeel te kunnen beslechten, hebben de belangencoalities die zich achter zo'n narratief hebben geschaard ook in een postdemocratisch tijdperk het auratische gezag van wetenschappelijke fundering nodig. En Academia levert, en levert graag, onder het motto: U vraagt, wij draaien.

Steeds minder kent Academia daardoor een eigenstandige, maatschappijkritische taakopvatting. Steeds vaker verlaagt ze zich tot de rol van hooggekwalificeerde prostituee van een wankele maar zelfingenomen elite. Zeker als deze zich via de agenda van de kenniseconomie opwerpt als haar grootste fan.

Het is een gevaarlijke strategie. Hoerigheid is geen goede basis voor duurzaam gezag. De universiteit loopt het levensgrote risico net als het $\mathrm{HBO}$ een domme certificeringsmachine te worden. Dan zullen burgers op zoek moeten naar andere tegenmachten om de lulkoek van de elite de maat te nemen. Ik hoop van ganser harte dat mijn bestuurders bijtijds het gevaar zien. Maar ik vrees het ergste. Als de elite lonkt, dooft de kritiek.

\section{Ewald Engelen (e.r.engelen@uva.nl) is hoogleraar financiële geografie aan de Universiteit van Amsterdam en vaste colum- nist van de Groene Amsterdammer. Een verkorte versie van dit artikel getiteld 'De onstuitbare opmars van de bestuurlijke larie' is 22 juli 2011 verschenen in NRC Handelsblad/Next.}

\author{
Literatuurselectie \\ Crouch, C. (2004) Post Democracy. Cambridge, U.K.: Polity Press \\ Engelen, E. (2007) Amsterdamned'? The uncertain future of a \\ financial centre. Environment and planning A. 39, nummer 6, pp \\ 1306-1324. \\ Engelen, E., et al. (2010) Reconceptualizing financial innovation \\ frame, conjuncture and bricolage. Economy and Society vol. 39, \\ nummer 1. pp. 33-63. \\ Engelen, E. et al. (2011) After the great complacence, financial \\ crisis and the politics of reform. Ofxord: Oxford University Press. \\ Frankfurt, H. (2005) On Bullshit. Princeton, N.J.: Princeton \\ University Press.
}




\title{
Crisis redt ruimtelijke ordening
}

\author{
AUTEUR \& FOTOGRAFIE Leonie Janssen-Jansen
}

Wie buiten om zich heen kijkt, ziet een enorm overschot aan vastgoed variërend van leegstaande kantoren en winkels en eindeloos te koop staande woningen tot stilliggende bouwprojecten. In de vakwereld en media krijgt de financiële crisis de schuld. Maar is de crisis wel de schuldige? Of juist de redding van de ruimtelijke ordening?

Hoewel de economie al enige tijd herstel heeft vertoond, blijft de situatie op de vastgoedmarkten zorgelijk. De leegstand van kantoorgebouwen, bedrijfs- en winkelpanden is groot en groeit. Projecten liggen stil en woningen blijven onverkocht. Ontwikkelaars, bouwbedrijven, makelaars, architecten, maar ook gemeenten hebben in de hoogtijdagen enorm veel plannen gemaakt en ontwikkelingen zijn gestart op basis van te rooskleurige cijfers en zonder haalbaarheidstoets. Nu hebben al deze partijen het moeilijk.

Steeds luider klinkt de roep om een oplossing, maar een eenduidige benadering ontbreekt. Het probleem is complex met veel verschil-

lende en zelfs tegenstrijdige belangen. De oorzaak van de problematiek is onderbelicht in de discussies. Er wordt te gemakkelijk vanuit gegaan dat de problemen in de ruimtelijke ordening zijn veroorzaakt door de financiële crisis. Door een externe oorzaak als excuus voor het interne falen van de ontwikkelingssector te gebruiken, worden structurele problemen, en de omvang daarvan, ontkend. Het gaat hier om de ontwikkelingsluchtbellen en -luchtkastelen die gecreëerd zijn in tijden van een overvloedige hoeveelheid geld, ambities, optimisme en een sterk vertrouwen in altijd maar groei.

Hoewel in andere sectoren zoals de IT zeepbellen uit elkaar zijn gespat, bleven ontwikkelaars, wethouders, stedenbouwers en projectleiders in de ruimtelijke ordening inzetten op het maken van nieuwe plannen. De grote hoeveelheid goedkoop geld versterkte dit. Dure woningen en kantoren waren het meest lucratief vanuit het oogpunt van verwachte grondopbrengsten en dit is zichtbaar in de gerealiseerde en geplande ontwikkelingen. De behoefte en wensen van burgers en bedrijven speelt slechts een geringe rol. Maar juist ontkenning van deze vraagzijde heeft geleid tot de huidige problemen. Toen structurele problemen zichtbaar werden, bijvoorbeeld door hoge leegstandspercentages van kantoren in 2005, bleven beleggers, ontwikkelaars en gemeenten volop plannen maken. De marktpartijen verwachtten op basis van eerdere projecten veel winst te kunnen maken. Gemeenten waren gewend geraakt aan een constante en continu groeiende bron van gronduitgifte-inkomsten en grondexploitatiewinsten, waarmee in hun stad geïnvesteerd werd (bijvoorbeeld in de vaak zeer gewenste herstructurering van oude wijken). De verwachte winsten zijn vaak op papier al ingezet voor financiering van voorzieningen, als bijdrage aan andere bouwprojecten, etc.

\section{De som van voorspelde werkgelegenheidsgroei in alle gemeenten in Nederland wijkt nogal af van de voorspelde $10 \%$ krimp in de beroepsbevolking}

\footnotetext{
Al deze ontwikkelingen werden nagestreefd vanuit het idee dat mensen, winkels en bedrijven vanzelf komen als er genoeg aanbod is. Zoals de gemeente Medemblik in januari 2011 in haar collegeprogramma stelde: "Wij leggen ons niet neer bij mogelijke krimpscenario's. Bij woningbouw streven we naar groei. De baten van woningbouw worden ingezet voor gemeenschappelijke voorzieningen. De woningbouw moet worden afgestemd op de behoefte, echter die behoefte kan voor een deel worden gecreëerd".
} 


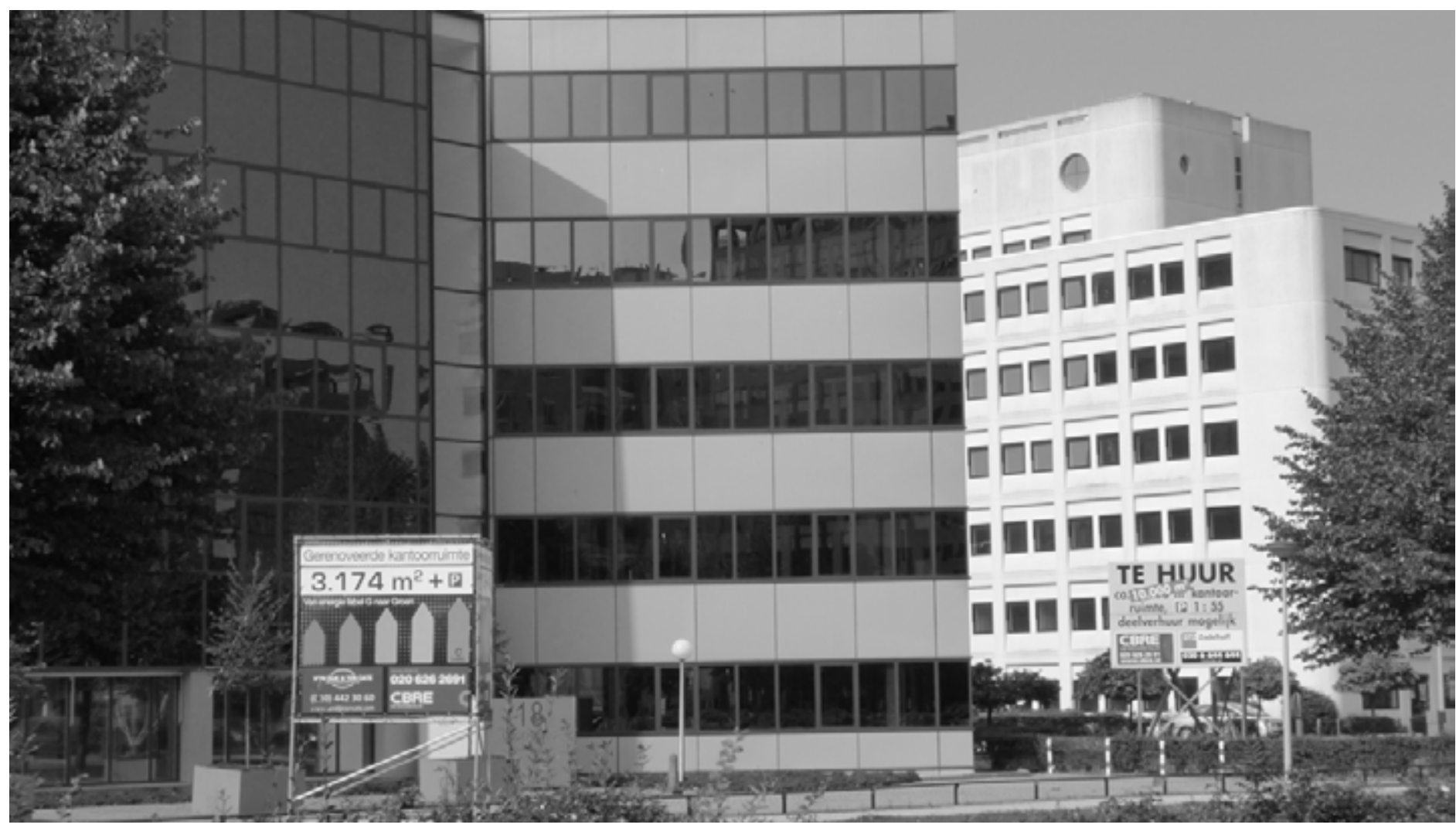

Leegstaande kantoorgebouwen worden aangeprezen, een steeds vaker voorkomend straatbeeld

Door dit soort redenaties is er niet alleen sprake van veel leegstand, maar tegelijkertijd is er nog onrealistisch veel nieuwbouw gepland voor kantoren, bedrijven, winkels maar ook voor woningen. Er zijn plannen voor honderdduizenden woningen op plekken beoogd waar er geen, of een andere vraag is.

De vele projecten tussen maar ook binnen gemeenten concurreren met elkaar. Er zijn al kosten gemaakt, bijvoorbeeld voor de grond, terwijl ook vaak al rekening gehouden is met de verwachte inkomsten van de ontwikkelingen. Als gevolg hiervan is er een zwaar financieel belang om aan al deze plannen vast te houden. 'Verlies' is moeilijk uit te leggen. Door de koppeling aan andere investeringen hangt er aan elk plan ook een groot politiek belang.

Het overoptimisme van de afgelopen decennia heeft op dit moment geresulteerd in grote financiële problemen, met dreigende faillissementen in de markt. Voor de gemeenten ligt verscherpt toezicht op de loer, waardoor er bezuinigd moet worden. Dit leidt tot minder voorzieningen en hogere gemeentelijke lasten voor burgers en bedrijven. Om dit te voorkomen wordt naar mogelijkheden gezocht toch te ontwikkelen, desnoods in een aangepaste vorm. De vraag is of dit verstandig is.

\section{Garbage in, garbage out}

Het hoogste groeiscenario van het centraal planbureau (CPB) uit 2004, 'Global Economy' is vaak als uitgangspunt gebruikt voor de ontwikkelingen, in elk geval voor de economische groeicijfers. De enorme bevolkingsgroei (tot bijna 20 miljoen) die hiervoor nodig is, wordt vaak genegeerd, evenals het feit dat de huidige bevolkingsontwikkeling helemaal niet aansluit bij hoge groeiscenario's. Het gebruik van scenario's met hoge groei is niet voorbehouden aan gemeenten. Het Randstad 2040-rapport stelt dat "het gebruik van relatief hoge scenario's bij de ambitie van het kabinet om de Randstad te laten uitgroeien tot een topregio in Europa" past. Ook in de recent verschenen ontwerp-structuurvisie infrastructuur en ruimte figureert het 'Global Economy' scenario veelvuldig. Dit soort scenario's en prognoses gaat nogal eens een eigen leven leiden. Elke actor kiest voor wat het dichtst bij de eigen ambities ligt. Het worden 'waarheden' waar soms rigide aan vast wordt gehouden, zonder aannames en uitgangspunten, of consequenties ter discussie te stellen. Juist dit laatste (de vraag achter de vraag) is belangrijk. Als de huidige werkgelegenheidsprognoses van de Metropoolregio Amsterdam bijvoorbeeld kloppen, betekent dit bijvoorbeeld ook dat of de tijdelijke en/of permanente migratie moet gaan groeien (binnen- of buitenlands), of dat de mobiliteit toeneemt: mensen uit andere delen van Nederland komen in Amsterdam werken. Dit is niet het beeld dat voortkomt uit de werkgelegenheidsprognoses in andere delen van het land... Ook Arnhem, Breda en Den Bosch, etc. gaan uit van werkgelegenheidsgroei (zie ook pagina 17 van de ontwerp-structuurvisie van het ministerie van Infrastructuur en Milieu [I\&M]). Maar de som van alle voorspelde werkgelegenheidsgroei in alle gemeenten in Nederland wijkt nogal af van de voorspelde $10 \%$ krimp in de beroepsbevolking (zie ook pagina 14 van de ontwerp-structuurvisie I\&M). Deze inzet op groei door alle afzonderlijke gemeenten leidt tot groeiagenda's via meer woningen en meer kantoren, bedrijventerreinen en detailhandel. Het gaat daarbij vooral over kwantitatieve ambities, die ook nog eens allemaal hetzelfde zijn. Er is heel weinig zicht op de mensen (en bedrijven) erachter, ondanks mooie woorden dat 'kwalitatief' wordt aangesloten bij de 'daadwerkelijke vraag'. Wonen (en werken) 
worden gezien als bouwopgave. Deze bouwopgave wordt vervolgens weer als input meegenomen in bevolkingsprognoses.

Naast de krimp van de beroepsbevolking is er ook een aantal andere trendbreuken en discontinuïteiten zichtbaar, die ook nog eens de betrouwbaarheid van de gehanteerde trendmodellen voor prognoses vermindert. Zo is de kredietbubble geknapt. Hierdoor beschikken woningzoekenden maar ook investeerders in commercieel vastgoed over minder budget, dat door allerlei nieuwe financiële regelingen en eisen ook minder gemakkelijk is in te zetten. Maar er zijn meer discontinuiteiten: de migratie neemt af, de leeftijd waarop kinderen het huis verlaten stijgt, de woonduur van mensen onder de 35 jaar neemt toe. Ook de woningbezettingsgraad liet in 2010 voor het eerst sinds jaren in Amsterdam een stijging zien. Zijn dat jongeren die thuis blijven wonen; arbeidsmigranten die samen een huis delen? Daar is nauwelijks zicht op.

Niemand heeft er echter belang bij deze prognoses, de input of het model zelf ter discussie te stellen. Maar als deze input of het model niet klopt, klopt er niets van de prognose. En ook bij de interpretatie van prognoses en de vertaling daarvan naar bouwopgaves ontbreekt reflectie nogal eens. Bijvoorbeeld: er wordt een groei in eenpersoonshuishoudens verwacht, maar dat een aanzienlijk deel daarvan een huishouden van een burger ouder dan 75 jaar betreft wordt nogal eens vergeten.

\section{Inhoud moet centraal staan, en niet de 'wow' factoren: winst, fictief rendement en schijnwerkelijkheden van toekomstige opbrengsten}

\section{Een nieuw, maar nog leeg hoofdstuk}

Nederland is begonnen aan een nieuw hoofdstuk van de geschiedenis van de stedelijke ontwikkeling. Zonder groei en zonder geld moeten duurdere herstructureringsopgaven worden aangepakt. Op dit moment zijn de bladzijden van dit hoofdstuk nog leeg. Betrokkenen wachten op elkaar en nemen nog te weinig hun eigen verantwoordelijkheid.

Het besef dat het niet vanzelf goed komt, begint maar langzaam te komen. De omvang van het probleem wordt echter nog steeds onderschat. Dat de zwarte piet naar de financiële crisis wordt geschoven en er een sterk geloof is dat, aldus de Vereniging van Nederlandse Gemeenten (VNG), het grootste deel van de tegenvallers zal worden terugverdiend bij een opverende economie, helpt daarbij niet.

Het risico is daardoor groot dat er gekozen wordt voor korte termijn oplossingen, die op langere termijn het ruimtelijke probleem juist vergroten. Projecten of gebiedsontwikkelingen die het gemakkelijkste 'dicht te rekenen' zijn of waar het snelst winst voor de markt te creëren is, krijgen dan prioriteit. Dit hoeven niet per se de projecten te zijn die het beste bij de vraag aansluiten of de meeste waarde voor de bevolking opleveren, en al helemaal niet als naar de langere

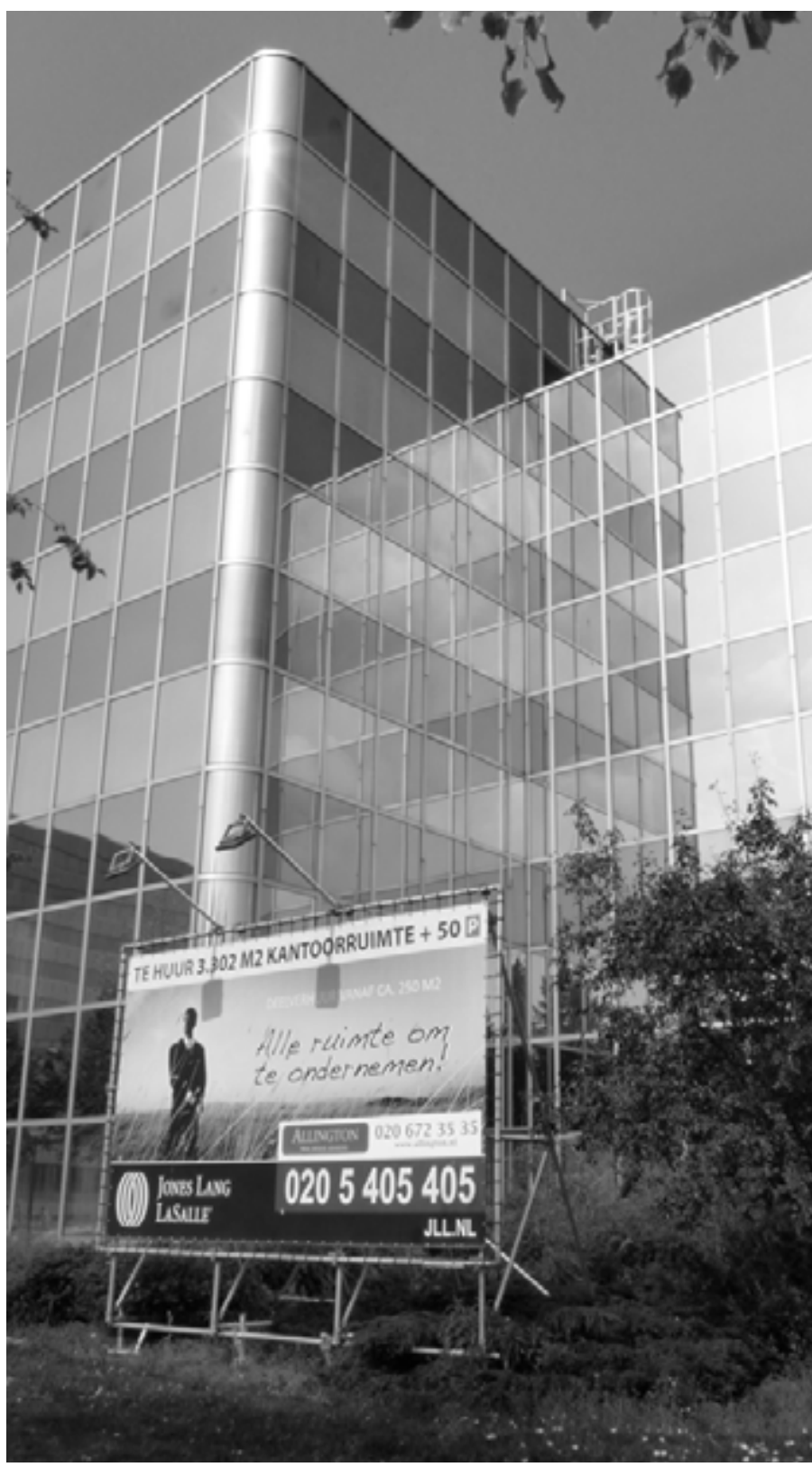

Meer realiteitszin onder planologen is nodig om een toename van leegstand te voorkomen

termijn wordt gekeken. Daarnaast is er het gevaar dat er nieuwe luchtbellen gecreëerd worden. Immers, voor elk project is op lokaal niveau nut en noodzaak aan te tonen. Er moet echter wel voorkomen worden dat de optelsom van deze projecten tot vergroting van het overaanbod leidt. Om dit collectief verlies te voorkomen dienen aannames kritisch bekeken te worden en de schaal en termijn van een business case van een project vergroot. Wat betekent de voorgestelde ontwikkeling in regionaal verband, en op de lange termijn? Om de complexiteit te reduceren worden oplossingen naar binnen gericht gezocht, maar daarmee wordt het grotere geheel uit het oog verloren. Het is juist belangrijk verder te kijken dan de genius loci van een project en bij programmeringsvraagstukken het project niet alleen vanuit het lokale schaalniveau te bekijken, maar ook in regionaal en soms zelfs bovenregionaal verband, en niet alleen op de korte, maar ook op de lange termijn. Hier ligt een belangrijke taak voor planologen. 


\section{Crisis leidt tot realiteitszin}

De ruimtelijke ordening moet weer meer realiteitszin krijgen en gezond worden. Om tot een robuuste oplossing te komen is selectiviteit en creativiteit nodig, en een duidelijke visie voor ruimtelijke ontwikkeling. Voor wie plan je wat, en waar? Gemeenten, provincies, en het Rijk moeten nadenken over hoe zij de ruimtelijke toekomst zien om een inhoudelijke afweging te maken tussen plannen. Het geërodeerde afwegingskader uit de tijd dat alles, en meer kon, moet herijkt worden in de nieuwe werkelijkheid.

Ook zonder crisis had dit moeten gebeuren, maar dan waren de luchtbellen eerst nog veel groter geworden. Met een nog pijnlijker uiteenspatten van deze bellen tot gevolg. In dat opzicht is de crisis de redding van ruimtelijke ordening, omdat de noodzaak voor realiteitzin niet meer ontkend kan worden. De crisis heeft het al bestaande probleem veel meer voor het voetlicht gebracht en tegelijkertijd door het stilvallen van projecten een aantal 'ontwikkelingsrampen' voorkomen.

Minimale scenario's, die wel flexibel zijn, zijn nu nodig. Dit vraagt om realistische plannen die kunnen worden bijgesteld als de realiteit anders wordt dan de aannames. Een gezonde dosis optimisme is belangrijk om kansen te blijven zien. Inhoud moet centraal staan, en niet de 'wow'-factoren, winst, fictieve rendementen en schijnwerkelijkheden van toekomstige opbrengsten die de afgelopen tijd de ruimtelijke agenda's van ontwikkelaars, wethouders, stedenbouwers, projectleiders in de ruimtelijke ordening gestuurd hebben, en soms nog steeds doen. De maatschappelijke kosten daarvan zijn te groot. Nagedacht moet worden over hoe publieke middelen zo effectief mogelijk zijn in te zetten. Om dit te doen moet goed worden gekeken wat de maatschappelijke opgave is, in het besef dat het bij de ruimtelijke ordening gaat om een complex systeem. Als er aan één tandwiel in het systeem wordt gedraaid om een ander in beweging te krijgen, gaan er heel veel meer wieltjes draaien, en sommige in omgekeerde richting.

Vanuit het ruimtelijke perspectief mag best vaker de 'waar zijn we mee bezig'-vraag gesteld worden. Planologen zullen daarbij een veel nadrukkelijkere rol moeten gaan spelen dan dat zij tot nu toe gedaan hebben. Planologen weten hoe het met de vraagkant van de ruimtelijke ordening staat, ook op een bovenlokaal schaalniveau en op de langere termijn. Zij zijn, op basis van de kennis die zij hebben of vergaren, sterk in het bedenken hoe de ruimtelijke ontwikkeling in de toekomst zou kunnen plaatsvinden en welke gevolgen dat heeft. Zij weten hoe het staat met de beschikbare plancapaciteit tegenover de vraag voor zowel wonen, werken als voorzieningen en zijn in staat te bestuurders adviseren over mogelijke en noodzakelijke strategieën gebaseerd op de realiteit in plaats van op een hype!

Leonie Janssen-Jansen (I.b.janssen-jansen@uva.nl) is werkzaam als Universitair hoofddocent Planologie bij de Universiteit van Amsterdam. Dit artikel is gebaseerd op het Pre-advies 'Ontwikkelingsbubbles en planningsdromen' dat zij in oktober 2010 voor de BNSP schreef en de lezing die zij op 23 juni 2011 in Delft hield voor de G32.
Literatuurselectie

Dienst O\&S, Gemeente Amsterdam (2010) Woningvoorraad en gemiddelde woningbezetting, 1 januari 2005-2010. Amsterdam: Gemeente Amsterdam.

Gemeente Medemblik (2011) Coalitieprogramma 2011-2014, VVD CDA PvdA CU PW2010, Vertrouwen in eigen kracht en verantwoordelijkheid. Medemblik: Gemeente Medemblik

Janssen-Jansen, L. (2010) Ontwikkelingsbubbles en planningsdromen, Optimism should be in the nature of planners, but over-optimism is a dead end street, Pre-Advies voor de BNSP. Amsterdam: BNSP.

Ministerie van Infrastructuur en Milieu (I\&M) (2011) Ontwerp structuurvisie infrastructuur en ruimte. Nederland concurrerend, bereikbaar, leefbaar en veilig. Den Haag: Ministerie van I\&M. Ministerie van VROM (Volkshuisvesting, Ruimtelijke Ordening en Milieubeheer) (2008) Randstad 2040: naar een duurzame en concurrerende Europese topregio. Den Haag: Ministerie van VROM. 
agora-magazine.nl

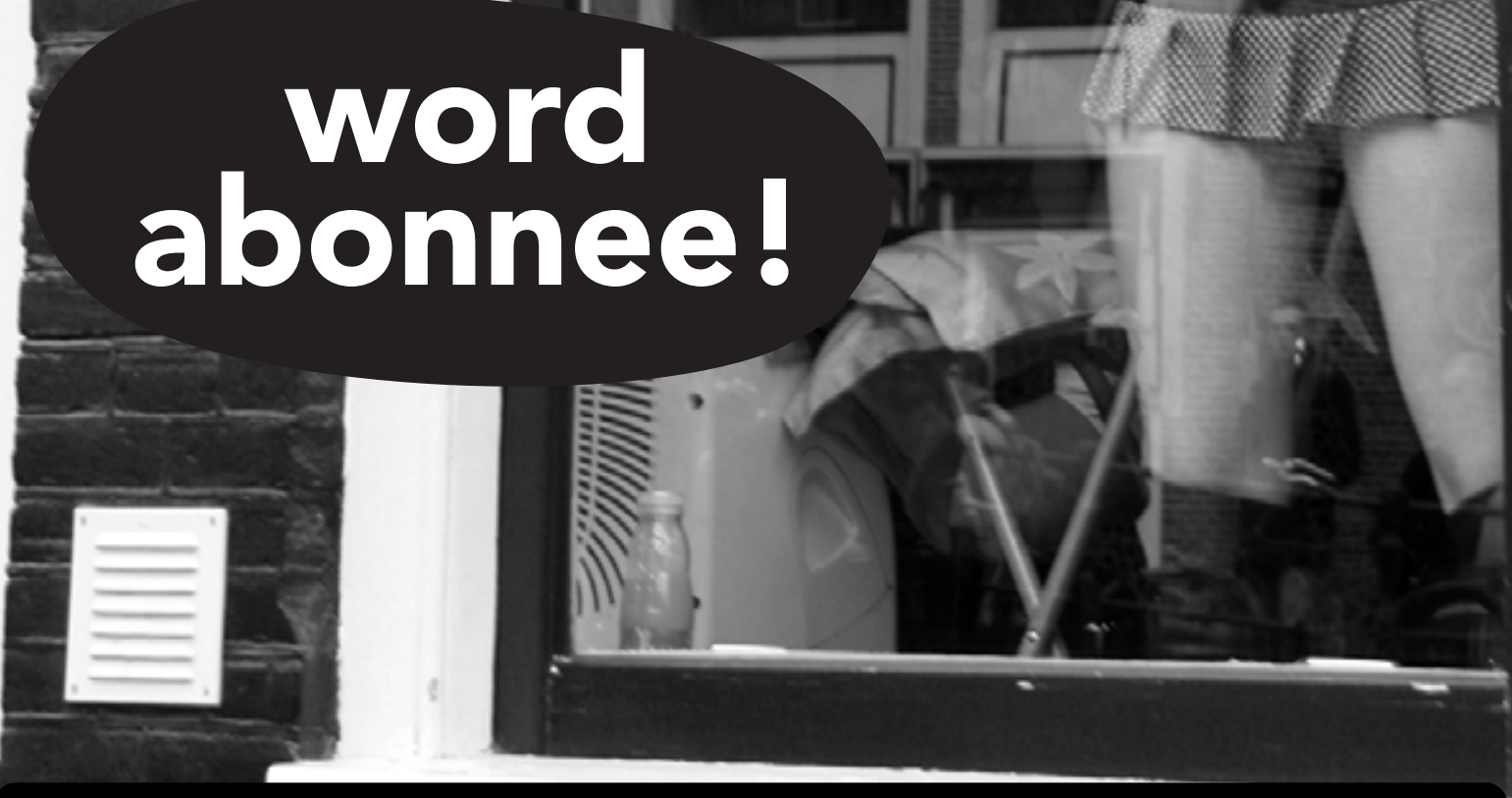

\section{word abonnee!}



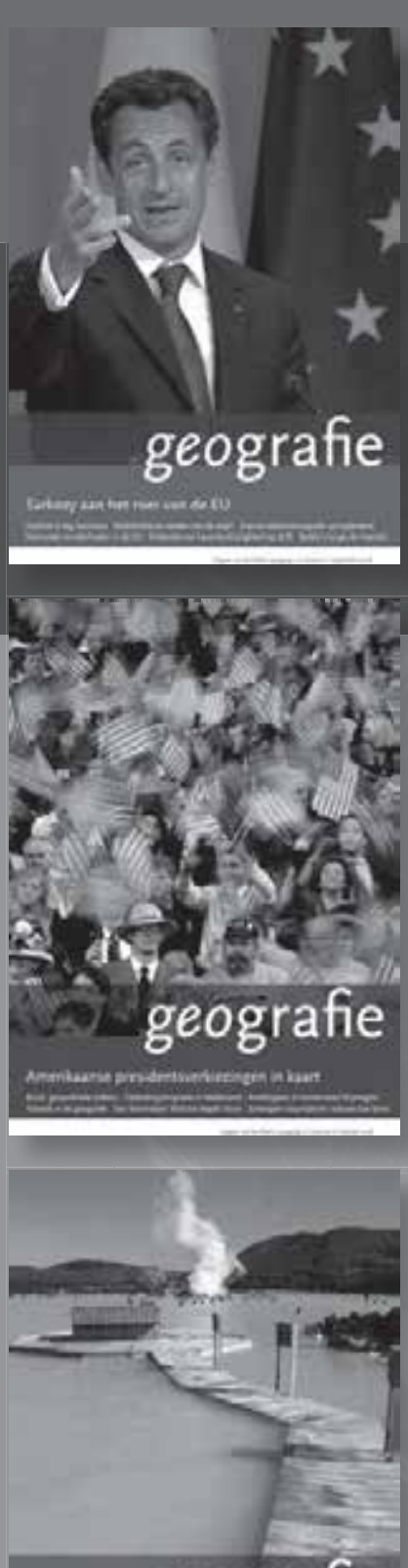

geografie

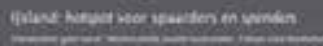

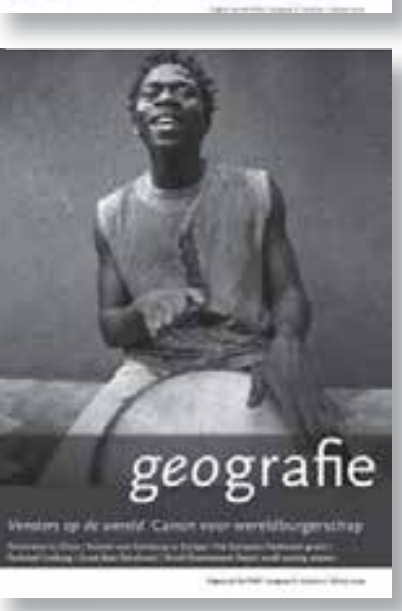

Geografie verschijnt negen keer per jaar en kost studenten slechts $€ 32$ per jaar, aio's en oio's betalen $€ 66,50$ (normale prijs $€ 89,50$ per jaar). Het lidmaatschap van het Koninklijk Nederlands Aardrijkskundig Genootschap (KNAG), het belangrijkste netwerk voor geografen in Nederland, is bij de prijs inbegrepen.

Kijk op www.geografie.nl of bel O3O 2534056 voor een abonnement. Een welkomstcadeau ligt klaar!

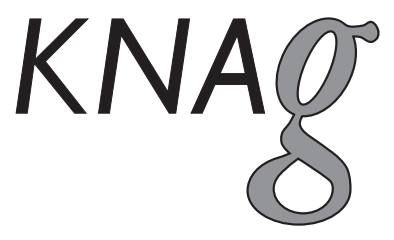

informatie over actuele ruimtelijke ontwikkelingen in Nederland en daarbuiten | reisverhalen | opinies achtergrondinformatie | recensies nieuwsberichten | columns | interviews | geografische agenda | boekbesprekingen | aanbiedingen ... 


\section{Een plek om vreemden te herkennen}

AUTEUR Gwen van Eijk en Hanneke Schreuders

FOTOGRAFIE Erwin Dijkgraaf

\section{Hoe kunnen publieke ruimten in herstructurerings- buurten bijdragen aan ontspannen overbruggende interacties? Contacten in publieke ruimten zijn vaak vluchtig en oppervlakkig. Maar juist hier kunnen mensen vertrouwd worden met 'culturele vreem- den'. Het herhaaldelijk zien en horen van anderen kan bijdragen aan publieke familiariteit.}

Sociale interacties in sociaal-economisch en etnisch gemengde buurten verlopen vaak stroef. Een reden hiervoor is wederzijdse onbekendheid met elkaars doen en laten en met andere culturen Herhaalde lichte interacties in publieke ruimten kunnen bijdragen aan meer bekendheid en vertrouwdheid met elkaar. Dat draagt niet alleen bij aan prettiger verblijf in publieke ruimten maar ook aan prettigere verhoudingen in de buurt en een gevoel van thuishoren en veiligheid. Alle reden dus om na te denken hoe inrichting, programmering en beheer van publieke ruimten zulke lichte interacties kunnen faciliteren.

In dit artikel bespreken we hoe publieke ruimten kunnen bijdragen aan lichte overbruggende interacties - dat wil zeggen: contacten tussen verschillende groepen mensen. Deze inzichten volgen uit een onderzoek naar ontmoetingen in de publieke ruimten in herstructureringsbuurt Poptahof in Delft.

Onder lichte interacties verstaan we korte, vluchtige en vaak oppervlakkige sociale interacties, zoals korte ontmoetingen op straat en observaties via het zien en horen van anderen. Mits ze herhaald plaatsvinden, dragen lichte interacties bij aan herkenning, bekendheid en vertrouwdheid met anderen in de publieke ruimten. Socioloog Talja Blokland noemt dat 'publieke familiariteit'. Zulke interacties dragen bij aan meer ontspannen overbruggende relaties omdat we zo het doen en laten van anderen leren herkennen en dus beter kunnen inschatten.

Het faciliteren van publieke familiariteit is vooral van belang in gemengde buurten omdat we daar vaker mensen tegenkomen die 'anders' zijn dan wij. Herstructureringsbuurten hebben vaak al een etnisch gemengde populatie. Verandering van de woningvoorraad heeft tot gevolg dat ook andere inkomensgroepen en bewoners met andere leefstijlen zich vestigen in de buurt. We komen daar veel 'culturele vreemden' tegen. Herhaalde ontmoetingen met deze culturele vreemden maakt hen minder vreemd en dus mogelijk minder beangstigend of bedreigend. Nadenken over lichte interacties en publieke ruimten is dus vooral van belang in het kader van herstructurering en mengingsbeleid. Dat maakt onze casus ook relevant voor andere buurten. We laten zien hoe inrichting en programmering zorgen voor een overlap van routes en routines in een winkelstraat en een park.

Daarnaast besteden we aandacht aan comfort, beheer en imago.

\section{Geïntegreerde routines en routes}

Een verscheidenheid aan voorzieningen en mogelijkheden voor activiteiten trekt verschillende soorten publiek. De integratie van routines en routes betekent dat verblijf en doorgang van verschillende groepen mensen overlappen waardoor zij gelijktijdig op dezelfde plekken aanwezig zijn. Succesvolle publieke ruimten zijn plekken waar mensen graag zijn. Een constante stroom van passanten betekent een constante aanwas van potentiële verblijvers. Dit zorgt voor levendigheid en biedt verblijvers iets om naar te kijken. Idealiter is er dus plek voor verschillende typen gebruikers: passanten die de publieke ruimten voornamelijk functioneel gebruiken - als verbindingsroute en voor de dagelijkse behoeften - en verblijvers die publieke ruimten óók gebruiken om hun sociale leven vorm te geven: ontmoeten van vrienden, familie en buren, recreatie en andere activiteiten.

\section{Poptahof}

De inzichten die in dit artikel naar voren komen volgen uit een onderzoek naar enkele publieke ruimten in herstructureringsbuurt Poptahof in Delft. Poptahof is een naoorlogse buurt; een combinatie van hoog- en laagbouw in de vorm van acht hofjes. De voor die tijd luxe appartementen waren bedoeld voor middenklasse huishoudens, die echter al snel vertrokken naar de buitenwijken. Omdat oorspronkelijk bijna de volledige woningvoorraad uit sociale huur bestond, trok de wijk veel lage inkomensgroepen aan, waaronder veel huishoudens van niet-Nederlandse herkomst (eerst gastarbeiders, later vluchtelingen).

De herstructurering (gestart in 2003 en nog volop in gang) heeft een meer gevarieerde woningvoorraad, verbetering van de leefbaarheid en reputatie en vernieuwing van de buitenruimten tot doel. Naast fysieke ingrepen lopen ook een aantal sociale, economische en culturele programma's. Het aandeel sociale huur en sociale koop wordt teruggebracht naar zestig procent. Dat betekent dat de populatie van de Poptahof meer gemengd wordt in termen van inkomensgroepen en leefstijlen. Daarbij worden de publieke ruimten ingericht met oog op overbruggende ontmoetingen. 


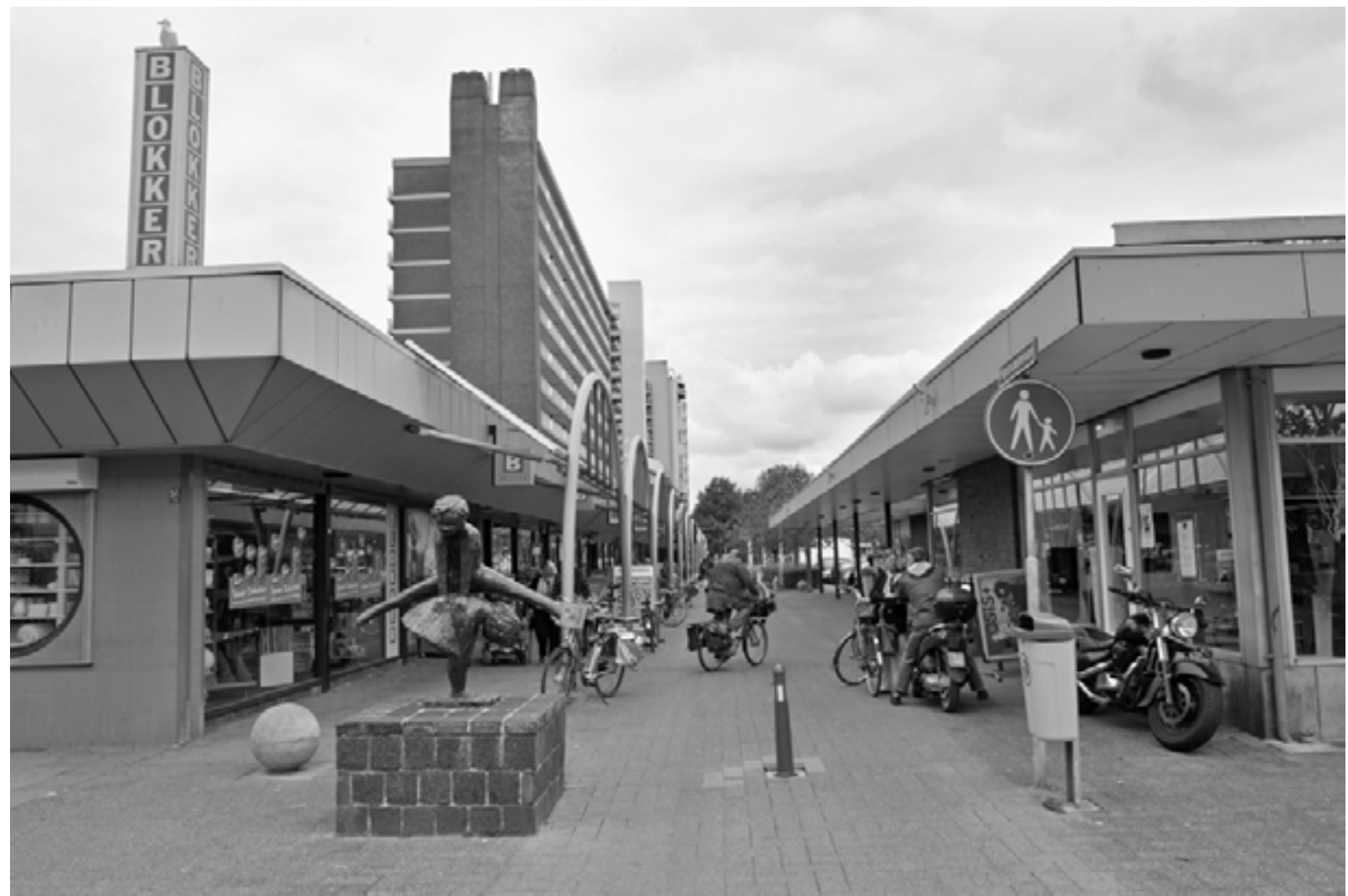

Winkelstraat de Papsouwselaan: mensen komen elkaar hier tegen tijdens hun dagelijkse routines

De winkelstraat en het Poptapark integreren routes en routines van bewoners en omwonenden met verschillende behoeften en leefstijlen. De winkelstraat doet dat vooral door de geografische mix van verschillende typen voorzieningen. Het park integreert routines en routes enerzijds doordat er plek is voor verschillende typen verblijf en anderzijds door ruimte te bieden aan zowel verblijf als doorgang.

\section{Elkaar zien en horen in het park}

Hoe inrichting gelijktijdig verblijf mogelijk maakt zien we in het Poptapark. Er is plek voor verschillende activiteiten. De waterspeeltuin en het grasveld nodigen uit tot spelen en de glooiende heuvels en de bankjes rondom de speeltoestellen bieden toeschouwers een plek. Het park nodigt dus niet alleen spelende kinderen uit, maar ook ouders en andere volwassenen om te kijken naar wat zich in het park afspeelt of gewoon om te relaxen.

De observaties laten zien dat verblijvers vaak uiteenlopende etnische achtergronden hebben. Professionals zien dit ook, maar menen dat er desondanks weinig overbruggende interactie is - Turkse moeders in de speeltuin, Antillianen langs het pad, Nederlanders weer elders. Echter, nemen we ontmoeten-via-observeren als uitgangspunt, dan zien we wel degelijk interactie. De verschillende groepen zitten vaak binnen elkaars gezichtsveld en binnen gehoorafstand. Daardoor kan via zien en horen wel een mate van publieke familiariteit ontstaan: herkenning over en weer en vertrouwdheid met elkaars activiteiten. Daarnaast zien we dat er sprake is van 'leven en laten leven'; verschillende groepen kunnen tegelijk gebruik maken van het park terwijl ze hun eigen activiteiten hebben.

Ook de aanwezigheid van passanten is van belang voor ontmoetenvia-observeren. Doordat het park centraal ligt "kun je niet om het park heen". Bovendien is het park naast verblijfsplek ook een verbindingsroute. Soms worden fietsers in een semi-voetgangersgebied als vervelend ervaren. Echter, in sociaal opzicht zijn passanten interessant. De mensen die het park opnemen in hun vaste fiets- of wandelroute gaan mensen en situaties herkennen. De bewoner die 's avonds nog een rondje loopt herkent bijvoorbeeld de jongeren die elke avond 'gewoon' met elkaar 'hangen'.

Voorts kan de juiste programmering lichte interacties en observeren stimuleren. Tijdens georganiseerde activiteiten zoals festivals geldt dat voor mensen die speciaal het festival bezoeken en zo met elkaar kennismaken, maar ook voor mensen die toevallig langskomen tijdens hun dagelijkse routines en ondertussen het spektakel en de toeschouwers aanschouwen.

\section{Onderzoek}

Het onderzoek richt zich op twee publieke ruimten in de Poptahof: het centraal gelegen Poptapark (reeds heringericht) en de winkelstraat aan de Papsouwselaan (nog te herinrichten). Gedurende vier seizoenen hebben onderzoekers en professionals die werkzaam zijn in de Poptahof observaties gedaan in de buurt en interviews gehouden met bewoners om zo inzicht te verkrijgen in het gebruik en de beleving van de publieke ruimten in de buurt.

\section{Geografische mix aan voorzieningen in winkelstraat}

De inrichting in de winkelstraat laat een ander aspect zien: de geografische mix van voorzieningen zorgt ervoor dat de routes van verschillende groepen mensen elkaar doorkruisen. Wanneer verschillende voorzieningen - de bekende 'Nederlandse' ketens, 'etnische' 
winkels, horeca en andere diensten - ruimtelijk zijn gesegregeerd, dragen ze niet of nauwelijks bij aan overbruggende ontmoetingen. Vooral geografische mix integreert routines en routes. De bewoonster die bijvoorbeeld enkel naar de Hollandse snackbar gaat loopt toch langs de Turkse eettent, en hoewel ze er nooit naar binnen gaat bieden de open etalage en het terras mogelijkheden om anderen te observeren.

Daarnaast is de toegankelijkheid van de winkelstraat een pluspunt. Een kleine winkelstraat zoals de Papsouwselaan is vaak een plek waar je komt om 'even snel wat te halen' en minder een verblijfsplek. Het open design (half-overdekt), de ligging langs de doorgaande weg en de strategische locatie maken dat mogelijk en trekken bovendien ook mensen van buiten de buurt aan. Ook ligt de winkelstraat op de route naar een grotere overdekte winkelpassage. Zo komen er veel passanten door de winkelstraat van de Papsouwselaan - ook de senioren van het nabijgelegen woon- en zorgcentrum - waardoor er altijd wel leven is op straat. De route is rollator-vriendelijk en de bankjes bieden gelegenheid onderweg wat uit te rusten. Uit onze observaties blijkt dat deze geografische mix van voorzieningen een succes is: de passanten vormen een zeer gemengd publiek en de etnische mix in de winkelstraat is groot op alle momenten van de dag, ook wanneer het niet druk is.

\section{Comfortabele plekken}

Naast inrichting en programmering speelt comfort een belangrijke rol. Comfortabele publieke ruimten zijn plekken die goed worden beheerd en onderhouden en die een goed imago hebben. Comfort draagt bij aan het behouden van een gemengd publiek en het faciliteren van lichte ontmoetingen. Verminderd comfort in een publieke ruimte wordt al snel geïnterpreteerd als 'verval' en kan voor sommige groepen bewoners reden zijn een plek negatief te

\section{Mits herhaald, dragen lichte interacties bij aan herkenning en vertrouwdheid met anderen in de publieke ruimten}

waarderen of zelfs te mijden. Een negatief imago kan een bedreiging zijn voor ontspannen overbruggende interacties. We bespreken enkele aspecten die bijdragen aan comfort: de gezinsvriendelijkheid van publieke ruimten, het beheer van deze ruimten en de kwaliteit van het winkelaanbod.

Volgens onderzoekers Boonstra en Hermens dienen publieke ruimten, vooral parken en pleinen, niet slechts kindvriendelijk maar gezinsvriendelijk te zijn. De aanwezigheid van volwassenen straalt uit dat er sociaal toezicht wordt uitgeoefend, ook wanneer er op dat moment niemand daadwerkelijk toezicht houdt. Ons onderzoek laat zien dat het Poptapark in de lente en zomer mensen van alle leeftijdsgroepen trekt, maar dat dit veel minder het geval is in de herfst en winter. In de natte en koude seizoenen fungeert het park vooral als speeltuin en trekt de plek weinig volwassenen en senioren. Kijken we naar de zitplekken, dan moeten we constateren dat die weinig beschutting bieden tegen regen en wind. Kinderen lijken bestand tegen regen en wind, maar volwassenen blijven dan weg, waardoor de diversiteit naar leeftijd en leefstijl in de natte en koude seizoenen afneemt. Comfort voor volwassenen kan dus leiden tot meer (ogenschijnlijk) toezicht op zowel kinderen als andere gebruikers en kan zo bijdragen aan een gevoel van veiligheid en comfort voor iedereen.

$\mathrm{Na}$ een drukke dag in het park blijft er veel afval achter. De waterspeeltuin ziet er mooi uit maar blijkt snel smerig te worden. De bankjes dragen al tekenen van gebruik: er wordt op getekend en hier en daar zijn brandplekken te zien. Bovendien zijn sommige groepen verblijvers luidruchtig, wat al snel als overlast wordt ervaren. Beheer is daarom essentieel voor comfort en imago, en zo voor het faciliteren van lichte interacties. Het is van belang dat er regels zijn voor het gebruik van de publieke ruimte. Dit kan duidelijk gemaakt worden door middel van een bord met leefafspraken, mits deze goed zichtbaar wordt geplaatst (in het Poptapark werd het bord door velen over het hoofd gezien). Daarnaast kunnen parkbeheerders - herkenbaar aan werkkleding - bijdragen aan toezicht en comfort. Zij zijn een paar extra ogen op straat, kanaliseren eventuele conflicten en houden het park 'schoon en heel'. Zo zijn er met de gebruikers afspraken gemaakt: barbecueën, bijvoorbeeld, mag mits de eigen rotzooi wordt opgeruimd. Daartoe zijn vuilniszakken verstrekt. Belangrijk is ook dat de regels voor iedereen helder zijn. Zo dachten de parkbeheerders dat voetballen in het park verboden was, maar ze konden dit moeilijk handhaven doordat dit nergens stond aangeven. Later bleek dat voetballen wel degelijk is toegestaan. Dat wekt niet alleen verwarring, maar ondermijnt ook het gezag van de beheerders. Regels moeten dus niet alleen duidelijk zijn voor bezoekers maar ook voor beheerders.

Tenslotte kan het slechte imago van publieke ruimten en van de buurt ontspannen overbruggende relaties dwarsbomen. Nieuwkomers in de buurt - de eerste kopers van de nieuwbouwwoningen - bleken niet allemaal met volle overtuiging voor de Poptahof te hebben gekozen; de gunstige prijs en ligging waren veeleer doorslaggevend. Zij uitten de hoop en verwachting dat het snel beter met de buurt zou gaan, maar volgden de ontwikkelingen met argusogen en bleken nog niet overtuigd van de stijgende lijn. Dit reflecteert in hun ervaring van de publieke ruimten. Vanwege het slechte imago van de buurt, worden slecht beheer en overlast door veel bewoners al snel als tekenen van verval gezien. Dit zagen we bijvoorbeeld in de winkelstraat.

De kwaliteit van de winkels functioneert als graadmeter voor de ontwikkeling van de buurt. Voorzieningen van twijfelachtige allure kunnen geïnterpreteerd worden als bron van onveiligheid en overlast. Het zien van winkels die vooral een 'vreemd' (onbekend, anders) publiek aantrekken kan bijdragen aan een gevoel van onbehagen: wat voor mensen zijn dit, waar gaat het heen met de buurt? Natuurlijk hoeven voorzieningen niet altijd iedereen aan te spreken. Een voorbijganger geeft aan: "sommige winkels zijn niets voor mij, maar er is hier voor ieder wat wils". Dit is ook een sterk punt. Echter, 


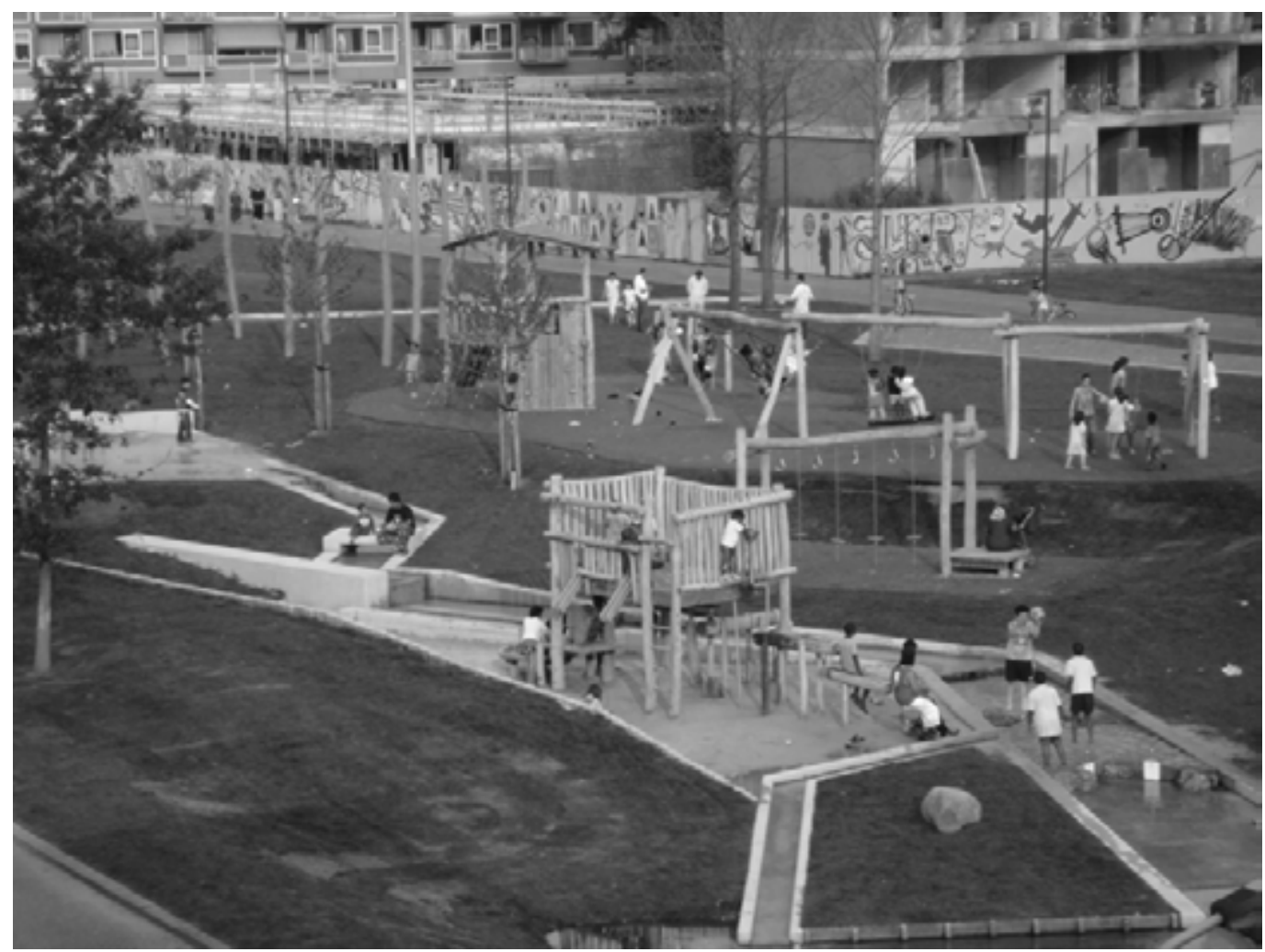

Poptapark: een plek waar mensen gepland en ongepland bij elkaar komen

winkels dienen wel aantrekkelijk en 'gepast' te zijn, bijvoorbeeld door open en nette etalages. Zo werden een Turks koffiehuis en een Eurowinkel als ongepast gezien. De eerste vanwege de verduisterde ramen (hebben ze iets te verbergen?), de tweede vanwege het aanbod (bijvoorbeeld de pornografische films, discreet geadverteerd als 'natuurfilms' in de etalage). Een Turkse snackbar werd als een verrijking gezien, vanwege het gezellige terras. Niet alle winkels hoeven alle bewoners te trekken, maar de winkeliers hebben toch een rol in het welkom heten van mensen.

\section{Tot slot}

Lichte interacties in publieke ruimten, mits ze herhaald plaatsvinden, kunnen bijdragen aan publieke familiariteit. Vreemden worden daardoor wat minder vreemd en minder bedreigend. Deze interacties zijn dus bij uitstek van belang in gemengde buurten en in herstructureringsbuurten. Sociale menging kunnen we dus ook zien in lichte overbruggende interacties, ook wanneer deze 'slechts' bestaan uit wederzijdse observaties en vluchtige ontmoetingen.

We hebben laten zien hoe zulke lichte interacties eruit zien in een park en een winkelstraat in een gemengde herstructureringsbuurt. We hebben daarbij gekeken naar een aantal voorwaarden voor succesvolle interacties. Ten eerste dienen inrichting en programmering verschillende routes en routines te integreren, zodat mensen elkaar ook daadwerkelijk tegenkomen en kunnen zien en horen. Ten tweede zijn comfort en imago niet alleen belangrijk voor een prettig verblijf maar ook voor de verhoudingen tussen groepen bewoners en gebruikers. Dit is vooral van belang in herstructureringsbuurten, die immers veelal kampen met een negatief imago. Beheer en aandacht voor publieke ruimte dragen bij aan prettige verblijfsplekken, waaraan bewoners kunnen aflezen dat het goed gaat met de buurt. Ten slotte dienen publieke ruimten niet alleen ingericht te worden met oog op een optimaal verblijf maar ook en vooral met oog op korte, spontane, overbruggende ontmoetingen. Elkaar zien en horen is óók een vorm van ontmoeten. De waarde van zulke lichte overbruggende interacties in de publieke ruimte mag niet worden onderschat in het licht van sociale menging en vertrouwdheid met elkaar.

Gwen van Eijk (g.vaneijk@uva.nl) is universitair docent en onderzoeker bij Urban Studies aan de Universiteit van Amsterdam. Zij voerde het onderzoek deels uit toen zij werkzaam was bij Onderzoeksinstituut OTB, TU Delft. Hanneke Schreuders (schreuders@sev.nl) is programmamedewerker bij de Stuurgroep Experimenten Volkshuisvesting (SEV). Het onderzoek in Poptahof is uitgevoerd in opdracht van en gefinancieerd door Projectorganisatie Poptahof, een samenwerkingsverband tussen Gemeente Delft en Woonbron Delft. De SEV begeleidde het onderzoek in het kader van haar experimentenprogramma Publieke ruimte: 'Where life swirls'.

\section{Literatuurselectie}

Blokland, T. (2009) Oog voor elkaar. Veiligheidsbeleving en sociale controle in de grote stad. Amsterdam: AUP.

Boonstra, N. \& N. Hermens (2009) Niet welkom op het plein. Veilige speelpleinen sluiten ook groepen uit. In: H. Boutellier, N. Boonstra en M. (red.) Omstreden ruimte. Over de organisatie van spontaniteit en veiligheid. Amsterdam: Van Gennep, pp. 33-48.

Eijk, G. van (2010) De vier seizoenen van de Poptahof: Ontmoetingen in de publieke ruimte. Rotterdam: SEV.

Lofland, L. (1973) World of strangers. Order and action in urban public space. New York: Basic Books. 
essen

\section{voor een}

krachtiger

stations-

beleid

AUTEUR Sander van Lent

FOTOGRAFIE Mizoguchi Coji

\section{Acht van de tien grootste stations in Nederland wor- den op dit moment verbouwd. Dit gaat gepaard met de herontwikkeling van het stationsgebied die door de complexiteit soms enkele decennia kan duren. Echter, de herontwikkeling van stationslocaties kan efficiënter worden uitgevoerd door het treffen van enkele pragmatische maatregelen.}

\section{Ontwikkeling van knoop en plaats}

Sinds de jaren negentig is er steeds meer aandacht voor de in de stad gelegen stationsgebieden. Door de ICT revolutie is er een nieuw netwerk ontstaan van aan elkaar gekoppelde beslissings- en kenniscentra en recreatie- en cultuurgebieden. Hierdoor ontstaat er een nieuwe werkelijkheid waarin niet de plek, space of places, maar stromen en netwerken, space of flows, een steeds belangrijkere rol gaan spelen. Deze space of flows kan zowel fysiek, vervoersinfrastructuur, als non-fysiek, communicatie- en informatienetwerken zijn. Als Nederland zich op de kaart wil zetten en haar internationale concurrentiepositie wil verstevigen, is het essentieel dat de steden deze koppelingen tussen space of places en space of flows goed faciliteren. Binnen deze benadering wordt een stationslocatie als de nieuwe toegangspoort van de stad gezien.

Door het tweeledige karakter van de stationslocaties, als knoop in de space of flows en plaats in de space of places, kan er in de stationsgebieden locatiesynergie ontstaan. Locatiesynergie vindt plaats als er een balans wordt gevonden tussen de knoopwaarde (vervoersfuncties) en de plaatswaarde (verblijfsfuncties) van een stationslocatie. De mogelijkheden tot locatiesynergie kan partijen tot een integrale aanpak bewegen waarbij twee partijen het voortouw nemen. Er is echter een veelheid aan actoren met eigen belangen actief op de Nederlandse stationslocaties. Deze bemoeilijken het ontwikkelproces. Denk hier aan busvervoerders, NS, ProRail, gemeentelijke overheden, ontwikkelaars, beleggers, particuliere eigenaars en omwonenden. Eveneens zorgen de wet- en regelgeving en inspraakmogelijkheden voor grote complexiteit en vertraging. Daar bovenop zorgt de economische crisis van eind 2008 voor nog meer stagnatie in het gehele ontwikkelproces van de stationsomgeving. De ontwikkeling van de binnenstedelijke stationsgebieden verloopt dan ook meestal niet zoals de gemeente wenst. De rijksoverheid geeft aan dat versterking van de bestaande centra belangrijk is, evenals een betere benutting van het bestaand gebied in samenhang met de infrastructuur en de vervoersknooppunten. Het Rijk erkent ook duidelijk dat de mogelijkheden tot de nieuwe centrumvorming afhankelijk zijn van de ruimtelijke- en marktpotenties van de locatie, van de ruimtelijke context, en van de verkeersen vervoersinfrastructuur. Zij laat het conditioneren en reguleren tot centrumvorming echter over aan de lokale overheden. De gemeenten zijn verantwoordelijk voor planvorming en samenwerking tussen de private en publieke sector. Door het lostrekken van de infrastructuur (knoop) en de ruimtelijke ontwikkelingen (plaats), door de ontwikkeling van infrastructuur en de conditionering van de ruimtelijke ordening bij de lokale overheid te leggen, blijft er een continue spanning tussen ruimte en mobiliteit, waarbij de lokale overheid de rol krijgt toebedeeld om tussen diverse belangen en ruimtelijke ontwikkelingen de publieke voorzieningen te creëren. Dit is een lastige kwestie gezien de vele actieve 'private' actoren die diverse belangen hebben en zich focussen op het 'individueel' eindproduct in plaats van het algemeen belang van de stationslocatie.

Het Rijk kan op verzoek van de gemeente wel een stimulerende rol vervullen door een financiële bijdrage te leveren aan de noodzakelijke investeringen in de infrastructuur. Een soortgelijke aanpak wordt gevolgd voor de Nieuwe Sleutelprojecten in Amsterdam Zuid, Rotterdam Centraal, Utrecht Centraal, Den Haag Centraal, Breda en Arnhem. Dit zijn integrale stedenbouwkundige projecten op en rond de stations van de hogesnelheidstrein in Nederland. Deze projecten zijn erop gericht hoogwaardige knooppunten te maken die de kern vormen van een vitaal centrumgebied voor kantoren en woningen. Het heeft als doel het (inter)nationaal concurrerend vestigingsmilieu van Nederland te versterken. De Nieuwe Sleutelprojecten zijn echter uitzonderingen op de regel en de ontwikkeling van het stationsgebied van de overige 265 stations in Nederland wordt dan ook voor het merendeel aan de lokale overheid overgelaten.

Om de ontwikkelingen van de nieuwe poorten te stimuleren en conflicten te voorkomen, kan de lokale overheid een nieuwe rol aannemen en krachtiger instrumenten inzetten waarbij het belang van de stationsomgeving als geheel boven de 'individuele' belangen van de betrokken actoren komt te staan.

\section{Bonus en verdeling}

Een les kan worden getrokken door de ontwikkeling van stationslocaties in Japan te beschouwen. Japan, en dan met name Tokio, kan terugkijken op een lange traditie op het gebied van stationsontwikkelingen. Ondanks het feit dat ruimtelijke ontwikkelingen in Tokio van geheel andere aard zijn dan die in Nederland, liggen de 


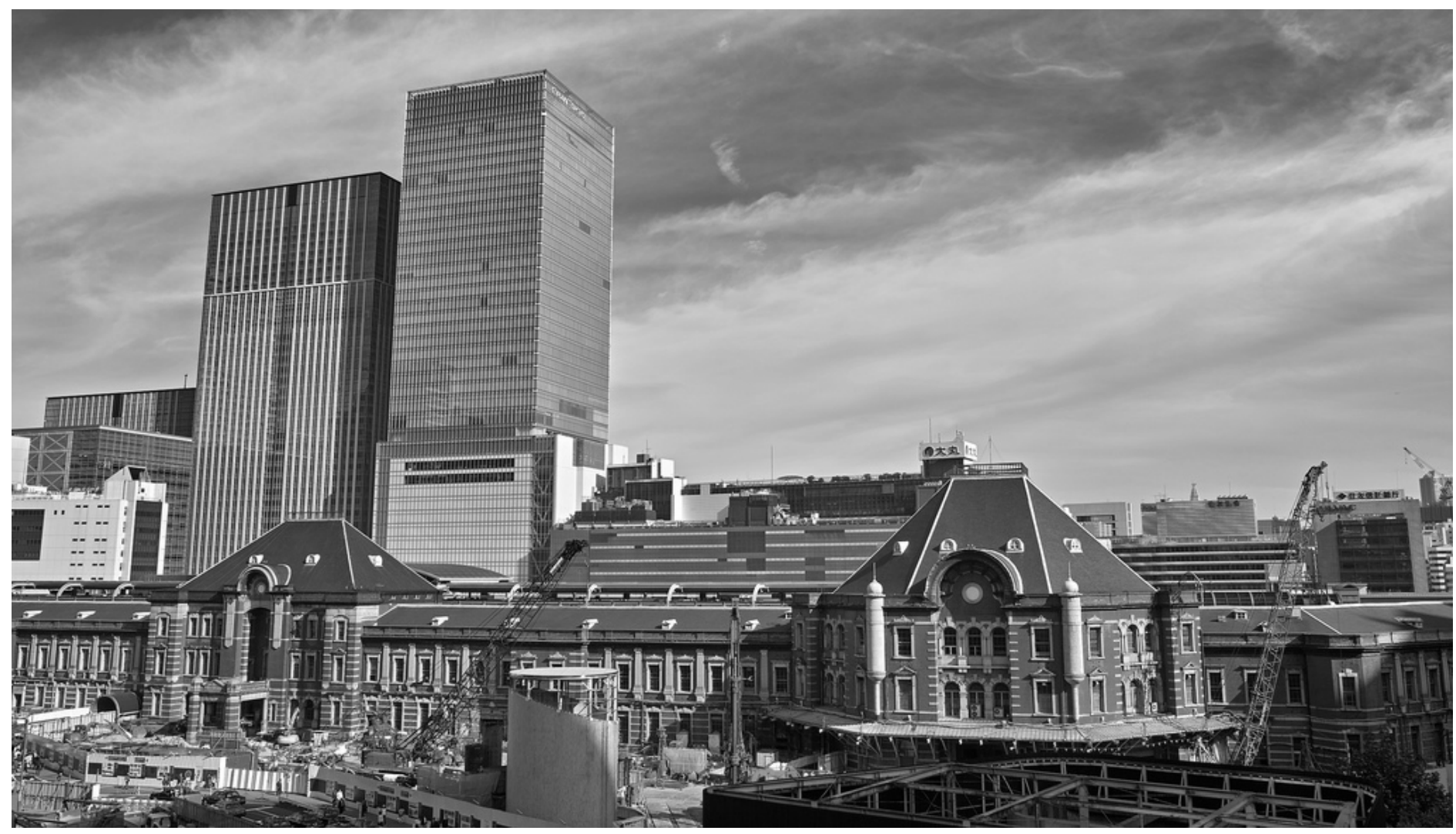

Stationsontwikkeling in Tokyo

leerpunten niet zozeer in de omvang van het ruimtelijk programma maar juist in de wijze waarop stationsgebieden organisatorisch worden herontwikkeld. Waar in Nederland het programma van het stationsgebied vaak door de lokale overheid wordt bepaald, bepaalt in Tokio veelal de markt de invulling van het ruimtelijke programma. De rol van de lokale overheid is conditionerend van aard en stelt de criteria op waaraan een stationsontwikkeling dient te voldoen. Hiermee geeft zij de markt de ruimte om zélf plannen te ontwikkelen, waar dit in Nederland juist traditioneel een taak van de overheid is. Naast dit fenomeen verleidt de Japanse overheid de private sector tot het doen van investeringen met als "stimulans" de Floor Area Ratio bonus (FAR-Bonus).

\section{In Nederland is onvoldoende publiek-private samenwerking}

Een private ontwikkelaar die investeert in publieke voorzieningen als infrastructuur, groen-, en parkeervoorzieningen genaamd de "Unused FAR", ontvangt hiervoor een extra bouwvolume bovenop de bouwvolumes die in de wet zijn voorgeschreven, de "Transferred FAR". Als een projectontwikkelaar bijvoorbeeld investeert in groenvoorzieningen in het stationsgebied, mag deze ontwikkelaar als blijk van waardering extra bouwvolume creëren op zijn eigen locatie binnen het stationsgebied. Het mes snijdt hierbij aan twee kanten: de lokale overheid profiteert omdat die 'gratis' publieke voorzieningen krijgt en de marktpartijen profiteren omdat ze meer kunnen ontwikkelen, wat hen in staat stelt de onrendabele investering in de publieke voorziening terug te verdienen. Dat deze methode aanlokkelijk is voor de private partijen blijkt uit de cijfers van het zakendistrict 'Marunouchi-Otemachi' waar de wettelijke bouwvolume maar liefst met tweeduizend procent is toegenomen.

Dit beloningsprincipe zorgt ervoor dat er middels overheidscondities gestuurd kan worden op ruimtelijke en infrastructurele kwaliteit waarbij infrastructuur de ruggengraat van alle ontwikkelingen vormt en private partijen rekening dienen te houden met de wisselwerking tussen ruimte en mobiliteit. De rijksoverheid kan, door het invoeren van de FAR-bonus, het tweeledige karakter van de stationsomgeving bij de diverse actoren benadrukken en een integrale aanpak bij private partijen afdwingen. Dit alles met als doel locatiesynergie te bereiken en de concurrentiepositie van de stad binnen het landelijk en/of internationale (trein)netwerk te versterken. Daarnaast wordt de 'ontwikkel' druk van de infrastructurele voorzieningen bij de lokale overheid weggenomen en kan zij zich nadrukkelijk richten op het bewaken van het eindresultaat van de gebiedsontwikkeling.

\section{Samenwerking en vertrouwen}

Naast de FAR-bonus en de coördinatierol die de lokale overheid zich kan aanmeten, is het van belang dat er vertrouwen en persoonlijk committent tussen de samenwerkende partijen ontstaat. Dit kan enkel als diverse partijen goed samenwerken, er transparant wordt gewerkt en elkaars vermogens worden gebundeld. Goed samenwerkende organisaties binnen grootstedelijke vraagstukken hebben tot succesvolle stationsontwikkelingen geleid, waar de Westelijke Spoorzone in 's-Hertogenbosch een goed voorbeeld van is. Alhoewel 
dit genoemde voorbeeld een uitzondering is, heeft het wel enkele wijze lessen opgeleverd. In 's-Hertogenbosch heeft de gemeente een organisatie- en besturingsstructuur gecreëerd die geen belemmering vormt voor de realisatie van de stationsomgeving. Om persoonlijk committent en vertrouwen te bewerkstelligen is een team van samenwerkende mensen opgesteld die vanaf het begin bij het ontwikkelproces van de stationsomgeving betrokken waren. Deze mensen vervulden een intermediaire rol tussen ruimte en mobiliteit en dienden goed de balans tussen publiek en privaat te vinden. Dat laatste blijkt in de praktijk lastig. Echter, 's-Hertogenbosch springt er hierin uit. De betrokken actoren zijn er door het interactieproces in geslaagd een formele samenwerkingsovereenkomst te sluiten met als centrale inhoud de gezamenlijke (her)ontwikkeling van het stationsgebied. Deze maatstaf voor succes is van belang nu in het eerste gedeelte van de overeenkomst is geconstateerd dat PubliekPrivate Samenwerking (PPS) in Nederland niet voldoende voorkomt. Vaak slagen actoren er niet in om het totstandkomingproces van een PPS effectief te organiseren en te doorlopen. In 's-Hertogenbosch is men daar wel in geslaagd en heeft men voor elk deelgebied een samenwerkingsovereenkomst tussen publieke en private partijen gesloten.

Voor het vormgeven en uitvoeren van een samenhangend beleid op het snijvlak van de beschreven werkgebieden en actoren zijn vakmensen nodig. De organisatie vanuit de (lokale) overheid dient dan ook te bestaan uit tussenpersonen die de belangen van private en publieke partijen kunnen doorgronden, als consultant kunnen fungeren en problemen centraal binnen de organisatie kunnen oplossen. Naast de technocratische kennis is communicatie, overtuigingskracht en interesse naar bedrijfsorganisatorische kennis noodzakelijk. In 2007 is het programma Ruimte \& Mobiliteit in het leven geroepen om de overheid te ondersteunen bij het effectief vormgeven en uitvoeren van een samenhangend beleid voor ruimtelijke ordening en mobiliteit. Hiermee is er een stap gezet in de goede richting, alleen heeft het programma geen passend vervolg gekregen. Wellicht de meest belangrijke partijen om zich in te zetten voor het afleveren van geschikte tussenpersonen zijn de onderwijsinstellingen en dan voornamelijk de studies Planologie, Stedenbouw, Bouwkunde, Civiele Techniek en Bouwtechnische Bedrijfskunde. Communicatiecursussen, leiderschapprogramma's en aandacht voor bedrijfskundige aspecten zijn naast de technocratische vakken belangrijke aandachtspunten om te zorgen dat de onderwijsinstellingen de markt en de overheid bedienen met echt capabele en multidisciplinaire individuen.

\section{Vergroten slaagkans}

Voor het slagen van een complexe opgave zoals de ontwikkeling van stationslocaties is het noodzakelijk dat diverse actoren (publiek en privaat) vanuit transparantie en met respect voor elkaars belang samenwerken en waarbij het doel van de stationsomgeving boven de belangen van de private partijen staan. Een instrument dat de lokale overheid kan inzetten om de ontwikkeling van nieuwe stationsomgevingen te stimuleren is de FAR-bonus. Hiermee heeft de lokale overheid een wapen in handen waarmee ze de markt kan verleiden tot het plegen van publieke investeringen. Door de markt een beloning in het vooruitzicht te stellen is de overheid in staat om extra kwaliteit af te dwingen waarvan iedereen profiteert. Indien de overheid in Nederland deze conditionerende rol wil vervullen, vereist dit zowel inhoudelijke als organisatorische veranderingen. Inhoudelijk, omdat met een conditionerende rol een andere taak voor de overheid is weggelegd dan met een regulerende rol. Organisatorisch, omdat er mensen nodig zijn die integraal over de sectoren heen kunnen kijken en ook in staat zijn om deze integrale denkwijze te implementeren binnen hun eigen organisatie. Onderwijsinstellingen zouden, met het aanbieden van enkele cursussen, hierop kunnen anticiperen om geschikte afgestudeerden (arbeidspotentieel) af te leveren.

Bovenstaande beleidstechnische en vakinhoudelijke veranderingen zijn in Nederland nodig om een stationsgebied sneller van de grond te krijgen. Door het neoliberale kabinet van Mark Rutte is wellicht een stap gezet naar een meer stimulerende en marktgerichte benadering vanuit de overheid, maar echt ingrijpende veranderingen zijn niet zichtbaar. Ook niet bij de onderwijsinstellingen, die de urgentie van communicatie en leiderschapsvaardigheden benadrukken, maar geen specifieke cursussen aanbieden.

\section{Sander van Lent (sanderlent@hotmail.com) is student Planologie aan de Universiteit Utrecht en afgestuurd Bouwtechnisch Bedrijfs- kundige aan de Hogeschool van Amsterdam.}

Literatuurselectie

Bertolini, L., en T. Spit (1998), Cities on rails, the redevelopment of railway station areas. E. \& FN Spon, Londen.

Bruil, I., F.Hobma, G.J. Peek, G. Wigmans (2004) Integrale gebiedsontwikkeling; Het stationsgebied 's-Hertogenbosch, SUN, Amsterdam

Castells, M. (1991) The Informational City: Economic Restructuring and Urban Development, Wiley-Blackwell,

Chorus, P. (2008a), Non-financial compensation instruments in Japan; The case of Tokyo, in L. Janssen-Jansen, M. Spaans and M. van der Veen (eds.) New instruments in spatial planning; an international perspective on non-financial compensation (Amsterdam; IOS Press). Chorus, P. (2008b), Transit-Oriented development in Tokyo; The public sector shapes favourable conditions, the private sector makes it happen, in C. Curtis, L. Bertolini and J. Renne (eds.) Transitoriented development; making it happen (Surrey; Ashgate) Lautenbach, R. (2008), Spoorzones; Integrale gebiedsontwikkeling en ruimtelijke kwaliteit, Amsterdam

Ministerie van Verkeer en Waterstaat, ministerie van Volkshuisvesting, Ruimtelijke Ordening en Milieu (2004), Nota Mobiliteit, Den Haag

Ministerie van Volkshuisvesting, Ruimtelijke Ordening en Milieu (2009),Spoorzoneontwikkeling; Een grote kans voor Nederlandse binnensteden, Den Haag

Peek, G.J. (2006), Locatiesynergie, een participatieve start van de herontwikkeling van binnenstedelijke stationslocaties, Eburon, Delft. Wigmans, G, G.J.P. Peek, F. Hobma, I. Bruil, (2004), Integrale gebiedsontwikkeling, Het stationsgebied van 's-Hertogenbosch. Sun, Amsterdam. 


\section{Externe effecten onder de microscoop}

AUTEUR Michiel van Meeteren

In de wetenschap en het maatschappelijke debat worden steden vaak gezien als 'motoren van economische groei' of 'brandpunten van innovatie'. Maar is dat terecht? Wanneer hebben bedrijven baat bij agglomeratie en wanneer niet? Geen onbelangrijke vragen in een tijd waarin sterk wordt ingezet op de rol van steden voor economische ontwikkeling.

Positieve en negatieve economische effecten van stedelijkheid worden wetenschappelijk aangeduid met de term 'agglomeratie externaliteiten'. Het zijn deze externe effecten die centraal staan in het proefschrift van Frank Neffke. Door toepassing van geavanceerde kwantitatieve methoden weet hij de kennis over deze effecten op een hoger niveau te tillen.

Toen mondialisering in de jaren negentig sterk om zich heen begon te grijpen ging het wetenschappelijke debat over de rol van steden in het postindustriële tijdperk. Onderdeel van die discussie was dat bedrijven 'footloose' zouden worden en zich overal kunnen vestigen. Dit hebben geografen als Allen Scott, Michael Storper en Richard Florida altijd sterk tegengesproken. Zij benadrukken juist dat het belang van de plaats alleen maar toe is genomen. Deze roep heeft extra geldingsdrang gekregen door het in zwang raken van het begrip 'kenniseconomie', waarbij opnieuw het belang van 'het lokale' wordt benadrukt. Een ander levendig wetenschappelijk debat gaat over de vraag of bedrijven nu juist baat hebben bij een concentratie van vergelijkbare bedrijven (lokalisatie economieën) of dat ze baat hebben bij een grote diversiteit aan bedrijven (de 'Jacobs externaliteiten'). De antwoorden op deze vragen zijn zeer genuanceerd, en vandaar dat het debat erover ook maar niet verstomt. Deze twee debatten vormen voor Neffke aanleiding om de externe effecten empirisch te onderzoeken.

De eerste twee empirische hoofdstukken laten zien dat agglomeratie effecten door de tijd heen inderdaad veranderen; door technologische ontwikkelingen en gedurende de levenscyclus van een technologie. Hieruit wordt duidelijk hoe een gediversifieerde en een gespecialiseerde stad elkaar in de weg kunnen zitten. Jonge bedrijven en industrieën kunnen baat hebben van leereffecten via andersoortige bedrijvigheid in de nabije omgeving. Tegelijkertijd zorgt een gebrek aan focus op lange termijn voor negatieve effecten, bijvoorbeeld doordat er onvoldoende draagvlak ontstaat voor gespecialiseerde dienstverleners. In de laatste twee empirische hoofdstukken wordt deze tegenstelling verder uitgediept.. Bedrijven blijken vooral van elkaar te leren als ze omringd zijn door bedrijven die anders zijn, maar waar de technologische afstand niet te groot is. Deze uitkomsten zijn niet baanbrekend, maar revolutionair is de gebruikte methode, waarbij hij de dynamiek van de technologische verwantschap in een maat weet te vangen. Deze maat, gebaseerd op metingen welke producten op dezelfde productielocatie gefabriceerd worden, stelt Neffke in staat de veranderingen in verwante productietechnologieën door de tijd heen nauwkeurig te meten. Doorgaans wordt deze verwantschap aangeduid via de zogenaamde SBI codering maar deze veroudert zo snel dat de verandering in de technologische verwantschap, die cruciaal is voor innovatie, helemaal buiten beeld blijft. Neffke's maat zou potentieel een instrument kunnen opleveren waarin toekomstige innovatieclusters en economische dynamiek tot op zekere hoogte te voorspellen zijn. Een economisch 'speerpunten-beleid' op basis van dergelijke kennis zou veel effectiever kunnen zijn dan het huidige, dat toch vaak de resultante is van een intensieve lobby van het gevestigde grootbedrijf. Neffke's proefschrift geeft echter geen 'kookboekoplossingen' voor een dergelijk beleidsinstrumentarium. Het proefschrift vraagt een aanzienlijke wiskundige en academische kennis om het op meer dan hoofdlijnen te kunnen volgen. Een proefschrift mag dat ook van de lezer vragen. Het is echter wel te hopen dat iemand die vertaling van deze bevindingen naar een beleidsinstrument ook zou willen bekostigen.

Opvallend is dat Neffke zich uitsluitend bedient van buitenlandse datasets. Zijn analyses vragen dan ook gedegen data op het niveau van individuele bedrijfslocaties. Somber stemt dan ook het idee dat de bevindingen van Neffke niet of nauwelijks te repliceren zijn met de gebrekkige data die Nederland van ondernemingen verzamelt.

Dit is de keerzijde van jarenlange bezuinigingen op bedrijfsenquêtes en 'vermindering van de administratieve lastendruk' voor ondernemingen. De kwaliteit van Neffke's proefschrift is dat het een tipje van de sluier oplicht wat een serieuze economisch geografische onderzoeksagenda en verbeterde dataverzameling een land aan strategische economische kennis zou kunnen opleveren. Als de ambitie van een door innovatie gedreven kenniseconomie meer is dan een holle hype, dan zouden beleidsmakers en politici hier een kans moeten pakken.

Frank Neffke (2009) Productive places. The Influence of Technological Change and Relatedness on Agglomeration Externalities. Universiteit Utrecht: Faculteit Geowetenschappen. Downloadbaar op: http://igitur-archive.library.uu.nl/dissertations/2009-0714-200508/neffke.pdf 


\section{Creatief hergebruik in Berlijn}

AUTEUR Trijntje Tilstra

FOTOGRAFIE Jan van Duppen

Niemand is er blij mee, maar elke stad heeft braakliggende terreinen of vervallen leegstaande gebouwen waarvan onduidelijk is wat er mee gebeurt. Jan van Duppen deed onderzoek naar de betekenis en potentie van deze plekken in Berlijn, op een plek waar zolang het niet bebouwd wordt, veel activiteiten plaatsvinden die van grote waarde zijn voor bewoners.

In zijn afstudeerscriptie 'The Cuvrybrache as Free Place' (2010) legt Van Duppen met interviews, observaties en foto's bloot wat de braakliggende Cuvrybrache voor zijn gebruikers betekent. Daarnaast wil hij met het onderzoek achterhalen hoe de activiteiten, verhalen en percepties in verhouding staan tot het neoliberale nieuwbouwproject 'Media Spree'. Al lezende is het niet moeilijk deze interessante plek in West-Berlijn voor te stellen: de treffende quotes, prachtige foto's en prettige schrijfstijl nemen je moeiteloos mee naar dit dynamische braakliggende terrein aan de oever van de Spree. De casestudie in Berlijn is niet voor niets gekozen: de geschiedenis en economische ontwikkelingen hebben diepe sporen in de stad achtergelaten. Na de Tweede Wereldoorlog werd Berlijn in tweeën verdeeld door de Muur en naast de resten zijn nog steeds veel onbestemde gebieden en lege kantoren te vinden.

De Cuvrybrache is één van die braakliggende terreinen. Het is een voormalig haventerrein in de wijk Kreuzberg dat al vijftien jaar op een nieuwe bestemming wacht. Tegenwoordig is het gebied in handen van projectontwikkelaar IVG, die er een groot kantorencomplex met lofts en een hotel wil bouwen. Dit plan, 'Neue Spreeseicher' genaamd, is onderdeel van 'Mediaspree', een neoliberaal herontwikkelingsproject dat het creëren van een mediacluster op deze plek tot doel heeft. De interesse van bedrijven blijft echter uit, en zolang omsluit een hek het verwilderde terrein.

Ondertussen hebben gebruikers het hek opengebroken en zich het terrein helemaal eigen gemaakt. En niet zonder succes: Voor veel mensen heeft de plek grote waarde. Er wordt gewandeld, gesport, graffitikunst gemaakt, gebarbecued, geblowd, muziek gemaakt, groente verbouwd maar vooral 'gechilld'. 'Vrijheid' is het sleutelwoord in de Cuvrybrache, en vrijwel alle quotes van de geïnterviewde gebruikers passen hierbij, bijvoorbeeld de respondent die de plek 'Kinderspielplatz für Große' noemt. Verder is de plek een belangrijke ontmoetingsplek voor diverse subculturen. Van Duppen gaat uitvoerig in op de belangrijkste drie: de graffitiscene, de guerilla gardeners (stedelijke moestuinen) en de fotografie- en filmgroepen. Om verschillende redenen leent de Cuvrybrache zich hier uitstekend voor: er is weinig toezicht, veel muren waarop de graffitikunstwerken goed zichtbaar zijn voor treinreizigers, er is genoeg ruimte voor een moestuin, en het heeft een rauw karakter dat een mooi decor vormt voor foto- en filmbeelden. Ondanks dat het tijdelijke projecten zijn, vormen ze een zichtbaar protest tegen de nieuwbouwplannen.

Volgens Van Duppen is er nog maar weinig kwalitatief onderzoek gedaan naar braakliggende terreinen en gebouwen, door de auteur ook wel 'informele openbare ruimtes' genoemd. Volgens hem draagt de uitgebreide analyse bij aan onderzoek naar betekenissen van plekken, en zet het vraagtekens bij de vaak negatieve benadering van braakliggende terreinen. Volgens Van Duppen bieden deze plekken enorm veel kansen en vormen ze een alternatief voor de 'formele' openbare ruimtes. Hiermee maakt Van Duppen meteen zijn belangrijkste punt: Het onderzoek is een pleidooi voor het loslaten van de drang om alles in de stad strak te plannen, in te richten en een duidelijke functie te willen geven. Hij pleit voor 'vrije' plekken, los van regels die bepaald sociaal gedrag opleggen. Dit doet Van Duppen overtuigend en uitgebreid, met een heldere opbouw van hoofdstukken en sterke relatie tussen theorie en empirie. Bovendien is het enthousiasme van de auteur af te lezen. Treffend hiervoor zijn de tentoonstelling en excursie die hij naar aanleiding van het onderzoek heeft (mede) georganiseerd. Een hoofdstuk hierover heeft hij als extraatje aan de scriptie toegevoegd.

\section{Het kleurrijke rapport laat zien dat braakliggende terreinen niet per se lelijk en duur hoeven te zijn}

Van Duppen wil met het onderzoek kunstenaars en de bewoners die tegen het 'Neue Spreeseicher' plan zijn een stem geven. Zij hebben het terrein getransformeerd naar een vrijplaats voor een scala aan activiteiten (zowel legaal als illegaal), die passen bij de 'do it yourself' mentaliteit van de creatieve Berlijners. Gebruikers krijgen de kans om er een eigen plek te creëren, waar ze de vrijheid hebben zichzelf te zijn en te doen en laten wat ze willen. Dit vormt tezamen met de verhalen en beelden die Van Duppen verzameld heeft een levendig protest tegen de nieuwbouwplannen.

Wel moet worden gerealiseerd dat Van Duppen weinig aandacht 


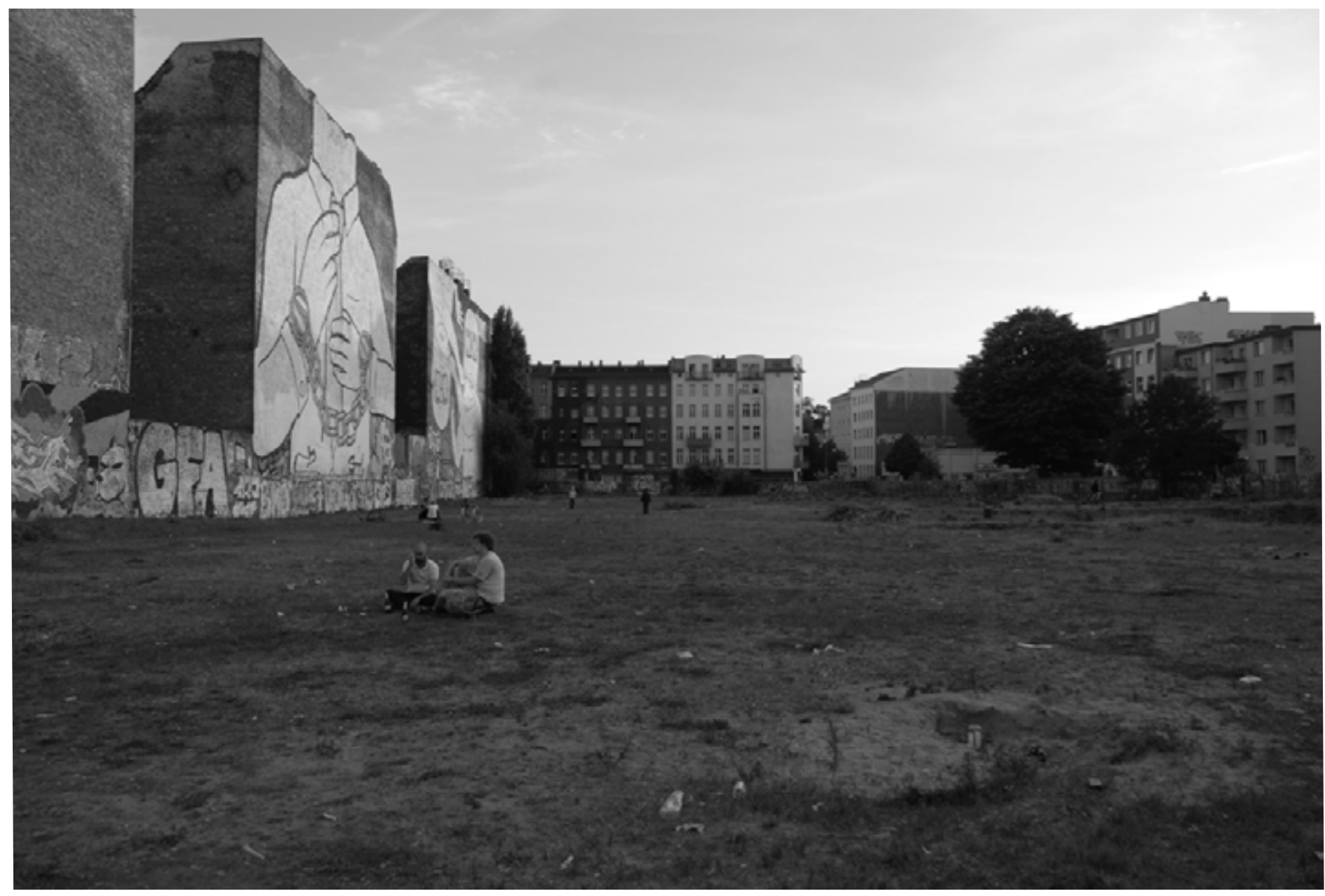

De Cuvrybrache: een braakliggend terrein dat functioneert als informele openbare ruimte

schenkt aan het feit dat andere bevolkingsgroepen minder op dergelijke 'vrije plekken' zitten te wachten dan de vrij homogene groep (creatieve jongeren) die de Cuvrybrache bezoekt. Ouderen en gezinnen bijvoorbeeld komen er nauwelijks, en toeristen nemen alleen voorzichtig een kijkje en gaan dan weer weg. Door de illegaliteit, de ontoegankelijkheid door het hek ende onzichtbaarheid door de insluiting van hoge gebouwen sluit de Cuvrybrache deze groepen grotendeels uit en heeft het niet de speciale waarde die het voor de eerdergenoemde kunstenaars en bewoners wel heeft.

De projectontwikkelaar is eveneens minder blij met de transformatie van zijn terrein naar een vrijplaats die gebruikt wordt voor tal van activiteiten. Niet alleen is er sprake van graffiti- en zwerfafvalproblemen, ook bestaat er de (terechte) angst voor groot protest tegen de bestemmingsplannen. Deze botsing tussen gebruik en beleving van gebruikers en de visie van beleidsmakers en (hier verwijst Van Duppen naar socioloog Lefebvre's 'lived' en 'conceived' space) komt zichtbaar tot uiting in het hek dat herhaaldelijk opengebroken is. Het is dan ook jammer dat projectontwikkelaar IVG niet inging op een interviewverzoek van de auteur, zodat hij het moest doen met beleidsdocumenten en gesprekken met een planner van de gemeente. Hierdoor blijft ook onduidelijk of en wanneer er nog gebouwd gaat worden, oftewel hoelang deze bijzondere 'free place' nog bestaat.
Om het antwoord op de onderzoeksvraag te krijgen - wat betekent de plek voor de gebruikers- hoeft men niet tot het slot te wachten. De plek betekent veel en is van grote sociaal-culturele waarde voor de wijk en diverse subculturen uit de hele stad. Van Duppen had hier aan toe kunnen voegen dat deze waarde vooral voor de bezoekers groot is en dat een dergelijke (non) inrichting niet overal zal werken. Sommige doelgroepen, zoals ouderen, hebben nou eenmaal behoefte duidelijkheid, of op zijn minst toegankelijkheid en veiligheid.

Van Duppen roept beleidsmakers en planologen op om op plekken zoals zulke braakliggende terreinen ter plaatse de betekenis te gaan onderzoeken in plaats van de stad vanaf het bureau 'in te vullen'. Dit betekent een grote omslag in denken. Langzamerhand komen begrippen als gebruik en beleving steeds meer terug in beleid. Het lezen van dit onderzoek kan de overheden goed helpen bij deze omslag. Braakliggende terreinen en leegstaande gebouwen zijn duur, lelijk en vooral erg leeg doordat er niks gebeurt. Van Duppen geeft genoeg inspiratie om hier iets aan te doen, of nog beter: om de burger hier iets aan te láten doen.

Jan van Duppen (2010) The Cuvrybrache as Free Place, The diverse meanings of a wasteland in Berlin. Utrecht: Universiteit Utrecht 


\section{Vrije ruimte}

\section{Het roer gaat om}

AUTEUR Zef Hemel

De laatste pagina van AGORA wordt vanaf heden gevuld door een wisselcolumn genaamd 'Vrije Ruimte'. Een prominent figuur uit de ruimtelijke sector kan hier in 700 woorden zijn visie, onvrede of verbazing uiten. Eenmalig en zonder restricties.

Ambtelijke molens malen traag. Geen hypes derhalve bij de rijksoverheid. Den Haag is nu al bijna twintig jaar bezig met het ontwikkelen van een nieuwe sturingsfilosofie voor ruimtelijk beleid. Stapje voor stapje wordt invulling gegeven aan het motto 'centraal wat moet, decentraal wat kan'. Men is, anders gezegd, vooral bezig met de eigen positie. Wat er dan centraal precies moest worden geregeld, bleef lang onduidelijk. Regelmatig viel het toverwoord 'selectiviteit'. Vanuit het land leek het echter alsof alles nog steeds in Den Haag werd bedisseld, daar ging men immers over de regeltjes en het geld. Die tijd lijkt voorbij. De departementale shuffle heeft ten slotte duidelijkheid verschaft. Op dit moment wordt er schoon schip gemaakt. De ruimtelijke inrichting van dit land wordt weer aangestuurd door de infrastructuur, zo valt te lezen in de nieuwe Structuurvisie. Bereikbaarheid wordt gezien als de structurerende kracht. Is dit nieuw? Nee, het is alsof we vijftig jaar worden terug gezet in de tijd. Op het hoogtepunt van het naoorlogse Modernisme werd immers ook mobiliteit gezien als een ruimtelijk bepalende kracht - automobiliteit dan met name. 'Nederland leefbaar, bereikbaar, veilig'. Voor een departement van Waterstaat mag het een geschikte spreuk lijken, voor de ruimtelijke inrichting van Nederland kan je er weinig mee, zeker als die leefbaarheid wordt omschreven als 'het versterken van de ruimtelijk-economische structuur'.

Het roer gaat om. Maar niet omdat zoveel ruimtelijk beleid zal worden gedelegeerd naar de provincies. Met de introductie van het begrip 'MIRT (Meerjarenprogramma Infrastructuur, Ruimte en Transport)-regio's' houdt het rijk immers de regie. Tweejaarlijks moeten alle regio's bij het Haagse departement verschijnen om over hun 'gebiedsagenda' te praten. Dit wekt centralisatie in de hand. Zodra het rijk aan de regio vraagt een gebiedsagenda te maken, mòeten gemeenten met elkaar tot een vergelijk komen, anders missen ze de boot. Op regionaal niveau werkt dit opportunisme in de hand, berekenend gedrag, onderlinge wedijver, eigen projecten naar voren schuiven, de hele taxonomie van machiavellistische manipulaties. De energie is niet positief. De inhoud staat niet voorop. Geen goede basis voor regionale samenwerking. Een tweede effect betreft het onbedoeld buitensluiten van burgers en private stakeholders. Door het MIRT-overleg is de focus op de overlegcircuits binnen en tussen de bestuurslagen gericht. De energie zit niet in het communiceren met de burgers. Dat heet 'bestuurlijke drukte'.
Een derde effect is het maar al te bekende verschijnsel van het overvragen. Dat begint al met het opbieden tegen andere regio's. De gebiedsagenda wordt een wensenlijstje van dikwijls peperdure projecten. In de MIRT-systematiek zijn mechanismen ingebouwd die overvragen moeten tegengaan. Ze leiden tot onzuivere reacties. De eis van ruimtelijke samenhang ontlokt een ruimtelijk beeld van geclusterde infrastructuurprojecten. De eis van een duidelijke scope en zicht op financiering heeft het effect dat juist de duurste projecten komen bovendrijven. En meebetalen resulteert in het zoeken naar extra verdiencapaciteit elders. Dus zal er uiteindelijk toch weer door het rijk naar de 'verdelende rechtvaardigheid' worden gegrepen. Zulk onvolwassen gedrag wordt deels door het MIRT-traject zelf uitgelokt. Het zit er als het ware ingebakken.

Een vierde effect betreft de dominantie van de infrastructuurplanning. Niet de ruimtelijke ontwikkeling blijkt in het MIRT voorop te staan, maar de infrastructuur. Alleen bij die laatste is namelijk geld te halen. Die houdt daardoor onverminderd vast aan haar eigen netwerklogica, terwijl zij haar infrastructuurvoorstellen met ruimtelijke argumenten onderbouwt. Dat is de omgekeerde wereld.

Gevolg van dit alles is dat de energie van de regionale bestuurders allerminst op de eigen regionale opgave wordt gericht. Een vervelende bijkomstigheid is dat stedelijke regio's nog feller met elkaar concurreren en de betrokken departementen proberen te paaien. Intern is sprake van grote bestuurlijke drukte. Extern heerst een ijzige stilte. Oprechte regionale samenwerking wordt op die manier door het rijk in de weg gestaan.

Is er een alternatief? Jazeker. Ondanks het rijk is regionale samenwerking de afgelopen jaren sterk gegroeid. De stedelijke regio's hebben zich van onderop georganiseerd. Dat gebeurt overal in de wereld. Steden doen er weer toe. Daarom zou het rijk de steden zeggenschap over hun eigen ruimtelijke toekomst moeten geven, inclusief de daarbij behorende budgets. Wat het beweert, zou het nu ook in praktijk moeten brengen. Harmonieuze regionale samenwerking ontstaat wanneer de volle verantwoordelijkheid in de stedelijke regio wordt gelegd. Pas dan gaat het roer ècht om.

Zef Hemel (z.hemel@dro.amsterdam.nl) is adjunct-directeur bij de Dienst Ruimtelijke Ordening Gemeente Amsterdam. 
AGORA - Magazine voor sociaalruimtelijke vraagstukken

2011 - 3 - jaargang 28

een uitgave van de Stichting Tijdschrift AGORA - ISSN 1380-6319

\section{REDACTIEADRES}

Redactie Tijdschrift AGORA

Faculteit Geowetenschappen

Universiteit Utrecht

Postbus 80.115

3508 TC Utrecht

[e] info@agora-magazine.nl

[i] www.agora-magazine.nl

[gironummer] 6165799

\section{REDACTIE}

Peter Pelzer (hoofdredacteur), Jesper van Loon (secretaris), Ate Poorthuis (penningmeester), Stephanie Vervaet (coördinator Vlaanderen), Wouter Bervoets, Valerie De Craene, Tessie Dijkers (variaredactie), Toon Dirckx, Tina Kelder, Bas van Leeuwen, Sander Lenferink, Martijn van der Linden, Michiel van Meeteren, Bruno Meeus, Michiel Overkamp, Katrien Plasschaert, Hanneke Posthumus (variaredactie), Inge Razenberg, Yvonne Rijpers, Karlijn Roex, Nick Schuermans, Evelien Taira Idrissi-Beckers, Trijntje Tilstra, Serge de Valk, Karolien Vermeiren, Sofie Vermeulen, Elien van de Vijver, Kirsten Visser, Anneleen De Vos.

\section{REDACTIEADVIEZEN}

Justin Beaumont, Marco Bontje, Heidi Hanssens, Henk van Houtum, Steven Kromhout, Ilse van Liempt, Maarten Loopmans, Tineke Lupi, Filip De Maesschalck, Ben de Pater, Bas Spierings, Casper Stelling, Justus Uitermark.

GRAFISCHE VORMGEVING

Jesper van Loon
ONTWERP HUISSTIJL

Maarten Mieras \& Jeroen Sikma

DRUK

A-D Druk bv - Zeist

ABONNEMENTEN (per jaar, vanaf 1 juni 2011)

Bibliotheken, bedrijven, instellingen

$€ 60,00$

Studenten

$€ 20,00$

Overigen

$€ 30,00$

KNAG-leden krijgen een korting van

$€ 5,00$

Abonnementen worden verlengd tenzij opgezegd uiterlijk 1 maand voor het verstrijken van de abonnementsperiode.

\section{ARTIKELEN}

Artikelen, mededelingen en reacties kunnen worden aangeboden aan het redactieadres. Dit geldt ook voor mededelingen en aankondigingen met betrekking tot congressen, studiedagen en andere evenementen op het gebied van de sociaalruimtelijke wetenschappen. Auteursrichtlijnen zijn bij de redactie beschikbaar. Artikelen overnemen is toegestaan met toestemming van auteurs en bronvermelding.

\section{ADVERTENTIES/SCRIPTIES}

Informatie via www.agora-magazine.nl of e-mail

De uitgave van AGORA wordt mede mogelijk gemaakt door steun van het Departement Sociale Geografie \& Planologie (UU), de Afdeling Sociale en Economische Geografie (KU Leuven), de vakgroep Geografie (UGent), de faculteit Ruimtelijke Wetenschappen (RUG) en het Koninklijk Nederlands Aardrijkskundig Genootschap (KNAG)

\section{(C) $\mathbb{Q} \otimes \odot$}

\section{Het volgende nummer}

De academische wereld kent de disciplines stadsgeografie en plattelandsgeografie, stadssociologen en ruraal sociologen. Toch bespreekt AGORA vaak 'stedelijke' thema's. Dat lijkt heel logisch, want Nederland en Vlaanderen kennen een hoge urbanisatiegraad. Wat overblijft is het platteland, dat vooral bestaat uit bos, landbouwgrond en kleine dorpen. Is dat zoveel anders dat de onderverdeling tussen stad en platteland in disciplines in de academische wereld gerechtvaardigd is?

Buiten de academische wereld is het beeld van het platteland niet altijd rooskleurig: leegstaande woningen en winkelpanden, ongenoegen over de landelijke politiek en Europa, verschraling van het voorzieningenniveau. Vergrijzing en een krimpende economie en bevolkingsomvang. Saai en ver weg. Hebben stedelingen echt dat beeld van het platteland? In hoeverre is dat beeld overeenkomstig met 'de werkelijkheid'? Waar komt die vermeende tegenstelling vandaan? Met het lezen van het volgende AGORA themanummer Platteland komt u tot de ontdekking dat niet alles is wat het lijkt: het platteland is verrassend dynamisch. 


\section{-.ADDruk}

Joh. Postlaan 4

3705 LN Zeist

Postbus 574

3700 AN Zeist

t 0306954000

f0306953483

info@addruk.nl

www.addruk.nl

\section{AD Druk in Zeist, dan een grafische partner}

Er zijn veel drukkerijen in Nederland.

Van grote rotatie-drukkerijen tot de bekende en vertrouwde drukker om de hoek.

AD Druk beweegt zich in het brede gebied tussen deze twee uitersten in.

Een gebied waar veel drukwerk wordt bedacht, waar vervolgens veel en hoge eisen aan de kwaliteit worden gesteld en waar uiteindelijk de mooiste grafische producten worden vervaardigd. In dat fascinerende gebied voelt AD Druk zich meer dan thuis, al jaren.

$A D$ Druk kan ook uw partner zijn als het gaat om ideeën, concepten en uitvoeringen van vele soorten drukwerk. $U$ praat met professionele mensen, die thuis zijn in alle facetten van de moderne, grafische wereld. Wij adviseren, raadplegen en helpen u juiste en verantwoorde keuzes te maken voor goed, verantwoord en duurzaam drukwerk.

AD Druk maakt deel uit van Adel Media, waarin DeltaHage en DigiPrint in Den Haag en Adel Print in Almere participeren. Voor u een vertrouwde basis voor de realisatie van drukwerk. Uw drukwerk!

\section{AD Druk, binnenkort ook uw partner?}




\section{-..ADDruk}

Joh. Postlaan 4

3705 LN Zeist

Postbus 574

3700 AN Zeist

t 0306954000

f 0306953483

info@addruk.nl

www.addruk.nl

\section{AD Druk in Zeist, méér dan een grafische partner}

Er zijn veel drukkerijen in Nederland.

Van grote rotatie-drukkerijen tot de bekende en vertrouwde drukker om de hoek.

AD Druk beweegt zich in het brede gebied tussen deze twee uitersten in.

Een gebied waar veel drukwerk wordt bedacht, waar vervolgens veel en hoge eisen aan de kwaliteit worden gesteld en waar uiteindelijk de mooiste grafische producten worden vervaardigd. In dat fascinerende gebied voelt AD Druk zich meer dan thuis, al jaren.

$A D$ Druk kan ook uw partner zijn als het gaat om ideeën, concepten en uitvoeringen van vele soorten drukwerk. $U$ praat met professionele mensen, die thuis zijn in alle facetten van de moderne, grafische wereld. Wij adviseren, raadplegen en helpen u juiste en verantwoorde keuzes te maken voor goed, verantwoord en duurzaam drukwerk.

AD Druk maakt deel uit van Adel Media, waarin DeltaHage en DigiPrint in Den Haag en Adel Print in Almere participeren. Voor u een vertrouwde basis voor de realisatie van drukwerk. Uw drukwerk!

\section{AD Druk, binnenkort ook uw partner?}

